\title{
ABOLISHING THE ACT OF STATE DOGTRINE
}

\author{
Michael J. Bazyler ${ }^{\dagger}$ \\ TABle of Contents
}

INTRODUCTION . . . . . . . . . . . . . . . 327

I. The Act of State Doctrine in Practice ...... 330

A. The Act of State Doctrine in the Supreme Court: No Clear Guidance .................. 330

B. The Act of State Doctrine in the Lower Federal Courts: Discord Among and Within the Circuits 344

1. The Second Circuit ................ 346

2. The Ninth Circuit ................ 348

3. The Third Circuit ................. 357

4. The District of Columbia Circuit ....... 359

C. Executive Pronouncements on the Act of State Doctrine: Inconsistent Recommendations ...... 362

II. Sowing the Seeds of Confusion: Problems GreATED By THE Act of State Doctrine . . . . . . 365 A. Fostering Widespread Confusion .......... 365

1. Disagreement About the Meaning and Scope of the Doctrine .................. 365

2. Disagreement About Exceptions to the Doctrine ..................... 368

a. The Bernstein Exception .......... 368

b. The Commercial Activity Exception .... 370

c. The Treaty Exception ............. 371

d. The Fraud Exception ............. 372

e. The United States Property Situs Exception .................... 372

f. The Human Rights Exception ....... 373

B. Violating the Separation of Powers Doctrine ... 375

C. Impairing the Effectiveness of United States Laws 376

1. The Foreign Sovereign Immunities Act.... 376

† Associate Professor, Whittier College School of Law. A.B. 1974, University of California, Los Angeles; J.D. 1978, University of Southern California. I would like to thank Anthony D'Amato, Paul Hoffman, Scott Wellman, and especially Jeanne Wilson, for their review of earlier drafts of this Article. 
2. The Antitrust Laws.................. . 378

3. The Securities Laws ... . . . . . . . . . . . . 379

4. The Foreign Corrupt Practices Act ...... 380

D. Impeding the Development of International Law in the United States . . . . . . . . . . . . . . . 381

III. Alternatives to the Act of State Doctrine .. 384

A. Sovereign Immunity ................ 385

B. Forum Non Conveniens ................. 385

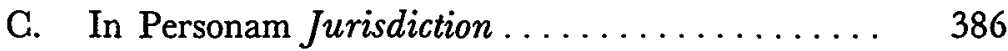

D. Choice of Law .................... 387

E. Foreign Sovereign Compulsion ........... 388

F. Political Question Doctrine .............. 389

IV. Legislative EfForts to Amend the Act of State Doctrine . . . . . . . . . . . . . . . . . . . . . . 392

A. The Hickenlooper Amendment. . . . . . . . . 392

B. The Mathias Bill . . . . . . . . . . . . . . . . . 394

C. The American Bar Association Proposal ...... 395

V. A Proposed Statute to Abolish the Act of State Doctrine .................... 396 Conclusion $\ldots \ldots \ldots \ldots \ldots \ldots \ldots \ldots \ldots \ldots \ldots . \ldots \ldots$ 
Let us recognize that the Act of State doctrine is in the same sacred realm as the full faith and credit clause and leave it alone.

-Michael H. Cardozo, Congress Versus Sabbatino: Constitutional Considerations

The bottom line is that this confused and outmoded doctrine frustrates the normal operation of the courts . . . and produces injustice in individual cases. ... The courts are mucking up the act of state [doctrine] all the time.

-Don Wallace, Jr., Statement Before the Subcommittee on Criminal Law of the Senate Committee on the Judiciary

\section{INTRODUCTION}

The judicially created act of state doctrine allows United States courts to abstain from deciding a case involving an international transaction on the grounds that one of the actors in the transaction is a foreign state. Even though the doctrine has spawned a wealth of cases ${ }^{1}$ and scholarly writings, ${ }^{2}$ neither courts nor commentators have been able to agree on the exact scope of the doctrine or the policies underlying its application. The act of state doctrine has been described variously as a doctrine of judicial prudence ${ }^{3}$ or deference, ${ }^{4}$ judicial re-

1 A WESTLAW search in December 1985 (ALLFEDS database) using the search term "act of state doctrine" yielded a list of 207 cases. Many of these cases are collected and discussed in Annot., 12 A.L.R. FED. 707 (1972 \& Supp. 1984).

${ }^{2}$ See Information Access Co., Legal Resource Index (microfilm service) (listing 141 entries under this topic as of October 1985). Some notable articles include Henkin, Act of State Today: Recollections in Tranquility, 6 Colum. J. TRANSNAT'L L. 175 - (1967); Mathias, Restructuring the Act of State Doctrine: A Blueprint for Legislative Reform, 12 LAw \& PoL'y INT'L Bus. 369 (1980); Zander, The Act of State Doctrine, 53 Am. J. InT'L L. 826 (1959); Comment, The Act of State Doctrine: A History of Judicial Limitations and Exceptions, 18 HARv. INT'L L.J. 677 (1977); Note, Rehabilitation and Exoneration of the Act of State Doctrine, 12 N.Y.U. J. INT'L L. \& PoL. 599 (1980) [hereinafter cited as Note, Rehabilitation and Exoneration]. See also Note, Limiting the Act of State Doctrine: A Legislative Initiative, 23 VA. J. INT'L L. 103, 103 n.1 (1982) (collecting authorities) [hereinafter cited as Note, Limiting the Act of State Doctrine].

${ }^{3}$ See International Ass'n of Machinists v. OPEC, 649 F.2d 1354, 1359 (9th Gir. 1981), cert. denied, 454 U.S. 1163 (1982); Comment, Applying an Amorphous Doctrine Wisely: The Viability of the Act of State Doctrine After the Foreign Sovereign Immunities Act, 18 TEX. INT'L L.J. 547, 551 (1983).

- See R. Falk, The Role of Domestic Courts in the International LeGAL ORDER 75, 105 (1964). 
straint, ${ }^{6}$ judicial abstention, ${ }^{6}$ issue preclusion, ${ }^{7}$ conflict of laws, ${ }^{8}$ and choice of law. ${ }^{9}$ As a result of all this confusion, courts habitually misapply the doctrine. ${ }^{10}$

First, courts use the doctrine as an excuse to avoid deciding difficult international transaction cases. Faced with difficult issues in an international transaction case, courts often simply pronounce that an act of state is involved and on that basis refuse to render a decision on the merits. This evasion by the courts has produced bitter reactions from unsuccessful litigants and scathing criticism from commentators.

Second, use of the act of state doctrine has resulted in violations of the long-cherished principle of separation of powers. ${ }^{11}$ Under our system of government, courts have a duty to exercise independent judgment in deciding cases. ${ }^{12}$ The act of state doctrine presents a startling exception to this rule. Under current practice, if the Executive suggests that a court apply the act of state doctrine in a particular case, the court will meekly comply with this suggestion. ${ }^{13}$ This complete deference to the Executive enables a litigant with political influence to enlist the Executive to intercede on its behalf ${ }^{\mathbf{1 4}}$ and tarnishes the image of the American judiciary as an independent branch of the government. ${ }^{15}$

- See Phoenix Canada Oil Co. v. Texaco Inc., 560 F. Supp. 1372, 1381 n.27 (D. Del. 1983); Laylin, Justiciable Disputes Involving Acts of State, 7 INT'L LAw. 513, 513 (1973); Lillich, Foreward to R. FALK, supra note 4, at vii.

6 See Hunt v. Mobil Oil Corp., 550 F.2d 68, 74 (2d Cir.), cert. denied, 434 U.S. 984 (1977); Mathias, supra note 2, at 372.

7 See National Am. Corp. v. Federal Republic of Nigeria, 448 F. Supp. 622, 640 n.30 (S.D.N.Y. 1978), aff'd, 597 F.2d 314 (2d Gir. 1979).

${ }^{8}$ See Industrial Inv. Dev. Corp. v. Mitsui \& Co., 594 F.2d 48, 51 (5th Cir. 1979), cert. denied, 445 U.S. 903 (1980).

- See Alfred Dunhill of London, Inc. v. Republic of Cuba, 425 U.S. 682, 705 n.18 (1976); Sharon v. Time, Inc., 599 F. Supp. 538, 546 (S.D.N.Y. 1984).

${ }^{10}$ See The International Rule of Law Act: Hearing on S. 1434 Before the Subcomm. on Criminal Law of the Senate Comm. on the Judiciary, 97th Cong., 1st Sess. 22, 22-24 (1981) (statement of Professor Don Wallace, Jr., Director of the International Law Institute, Georgetown University Law Center) [hereinafter cited as Act of State Hearings].

11 See infra notes 305-10 and accompanying text. For a discussion of the American tradition of separation of powers and its importance to our democratic system of government, see L. TRIBE, AmeriCan Constitutional LAw \$§ 2-1 to 2-4 (1978).

${ }_{12} C f$. L. TRIBE, supra note 11 , at $\S 2-1$ (noting that the different branches of government act within a "framework ultimately supervised by a disinterested judiciary").

13 See infra notes 270-77 and accompanying text.

14 See First Nat'l City Bank v. Banco Nacional de Cuba, 406 U.S. 759, 792 (1972) (Brennan, J., dissenting) (Judicial deference to the Executive through the act of state doctrine means that "the fate of the individual claimant would be subject to the political considerations of the Executive Branch. .... [S]imilarly situated litigants would not be likely to obtain even-handed treatment.").

15 "[T]he Court becomes a mere errand boy for the Executive Branch which may choose to pick some people's chestnuts from the fire, but not others'." First Nat'l City 
Third, the act of state doctrine has diluted the effectiveness of a number of important federal laws. The federal antitrust and securities laws, the Foreign Sovereign Immunities Act of $1976,{ }^{16}$ and the Foreign Corrupt Practices Act of $1977^{17}$ have all been undermined by the act of state doctrine.

Finally, and of primary importance to international legal scholars, the doctrine is probably the single most important reason for the arrested development of international law in the United States.

When a doctrine produces unfair results, courts often create exceptions to ameliorate its unfairness. ${ }^{18}$ The same has occurred with the act of state doctrine. While perhaps alleviating some unfairness, the exceptions to the act of state doctrine have also generated a great deal of confusion. Indeed, even the Justices of the United States Supreme Court cannot agree on which exceptions to the doctrine should be recognized. ${ }^{1 y}$

Faced with similar situations in the past, courts have taken the most logical route and abolished archaic doctrines. ${ }^{20}$ This Article will describe the numerous problems created by the act of state doctrine and argue that it too should be abolished, through either judicial or legislative action. Part I discusses the use of the act of state doctrine by federal courts. As will be shown, the decisions of these courts have created considerable confusion about the doctrine, and the confusion seems to be getting worse with each successive court opinion. Part II sets out the

Bank v. Banco Nacional de Cuba, 406 U.S. 759, 773 (1972) (Douglas, J., concurring in the result). For two recent cases in which the Executive chose to intervene and "pick some people's chestnuts from the fire," thereby resulting in the reversal of both district courts' act of state dismissals, see Allied Bank Int'l v. Banco Credito Agricola de Cartago, 757 F.2d 516, 519-21 (2d Cir. 1985), rev'g 566 F. Supp. 1440 (S.D.N.Y. 1983), cert. dismissed, 106 S. Ct. 30 (1985); Kalamazoo Spice Extraction Co. v. Provisional Military Gov't of Socialist Ethiopia, 729 F.2d 422, 425 (6th Cir. 1984), rev'g Ethiopian Spice Extraction Share Co. v. Kalamazoo Spice Extraction Co., 543 F. Supp. 1224 (W.D. Mich. 1982).

1628 U.S.C. $\S \S 1330,1332(\mathrm{a})(2)-(4), 1391(\mathrm{f}), 1441$ (d), 1602-1611 (1982).

1715 U.S.C. $\S \S 78 \mathrm{~m}(\mathrm{~b}),(\mathrm{d})(1)$, (g)-(h), $78 \mathrm{dd}-1$ to $-2,78 \mathrm{ff}(\mathrm{a}),(\mathrm{c})(1982)$.

18 Tort law furnishes some representative examples. Courts have created various exceptions and legal fictions to avoid the unfair results produced by the doctrines of contributory negligence, limited landowner liability, the fellow servant rule, and privity of contract. See W. Keeton, D. Dobbs, R. Keeton \& D. Owen, Prosser and KeeTON ON THE LAW OF TORTS 469-70 (5th ed. 1984) (contributory negligence); id. at 420-22 (limited landowner liability); id. at 572 (fellow servant rule); id. at 682 (privity of contract).

19 See infra notes 266-303 and accompanying text (discussing the disagreement that exists throughout the federal courts).

${ }^{20}$ A court's abolishment of an archaic legal doctrine is simply an application of the ancient English common law legal maxim, "Cessante ratione legis, cessat et ipsa lex" (The reason of the law ceasing, the law itself also ceases.). BLAck's LAw DicTIONARY 207 (5th ed. 1979). 
numerous problems that have resulted from application of the doctrine. Part III suggests that the policy concerns addressed by the vague and confusing act of state doctrine may be better served by a set of existing doctrines that have a more clearly defined scope and more secure theoretical underpinnings.

On a number of occasions, Congress has attempted to modify or abolish the act of state doctrine. The American Bar Association has proposed similar reforms. As noted in part IV, however, these proposals have been either too modest or too indirect to accomplish their intended purpose, and the courts have continued to apply the doctrine in a great number of cases. Part V sets forth a legislative proposal that would abolish the act of state doctrine in the event that the courts persist in their present course.

\section{The Act of State Doctrine in Practice}

Neither the United States Supreme Court nor the lower federal courts have set out fully the meaning and scope of the act of state doctrine. As a result, the doctrine has been applied in confusing and sometimes contradictory ways. ${ }^{21}$ This part will illustrate this confusion by discussing applications of the doctrine by the judicial and executive branches of government.

\section{A. The Act of State Doctrine in the Supreme Court: No Clear Guidance}

The United States Supreme Court first recognized the act of state doctrine in an 1812 case, The Schooner Exchange v. M'Faddon. ${ }^{22}$ The roots of the doctrine, however, can be traced back to seventeenth-century England ${ }^{23}$ and to a common origin with the doctrine of sovereign

${ }^{21}$ The ambit of the act of state doctrine has been described as being "so uncertain that [it] can afford little or no assistance to courts in other countries." Jones, Act of Foreign State in English Law: The Ghost Goes East, 22 VA. J. INT'L L. 433, 466 (1982).

2211 U.S. (7 Granch) 116, 146 (1812) (opinion by Marshall, C.J.):

The arguments in favor of [the doctrine] which have been drawn from the general inability of the judicial power to enforce its decisions in cases of this description, from the consideration, that the sovereign power of the nation is alone competent to avenge wrongs committed by a sovereign, that the questions to which such wrongs give birth . . . are for diplomatic, rather than legal discussion, are of great weight, and merit serious attention.

${ }^{23}$ The English case of Blad v. Bamfield, 36 Eng. Rep. 992 (Ch. 1674), is often cited as the common law source for the act of state doctrine. See, e.g., Banco Nacional de Cuba v. Sabbatino, 376 U.S. 398, 416 (1964).

In Blad the plaintiff, a Danish citizen, held a patent granted to him by the King 


\section{immunity. ${ }^{24}$}

During the heyday of European monarchies, the crown enjoyed complete immunity from suit. ${ }^{25}$ As monarchies declined, the state replaced the king as the sovereign entity, and state sovereignty came to be personified not by kings, but by state officials. ${ }^{28}$ While the state was still protected from suit by the doctrine of sovereign immunity, these state officials were personally exposed to suit for their official acts. The act of state doctrine developed in part to provide similar protection from suit for individual government officials. ${ }^{27}$

Act of state immunity therefore arose as nothing more than a corollary to sovereign immunity. ${ }^{28}$ Sovereign immunity protected the sovereign government against a lawsuit, while the act of state doctrine extended the same immunity to individual officials acting on behalf of their government. In The Schooner Exchange, the Supreme Court discussed the two doctrines together, recognizing the common origin of the two doctrines as well as the close dependence of act of state immunity upon sovereign immunity. ${ }^{29}$

The Supreme Court first treated the act of state doctrine as an independent source of immunity in an 1897 case, Underhill v. Her-

of Denmark that gave him exclusive trading rights with Iceland. The plaintiff sought to enforce the patent in England. The English court granted the plaintiff a perpetual injunction against suits brought by British subjects whose property was seized pursuant to the patent. In the course of the opinion, the court noted that to allow a court to determine the validity of the King's patent or a jury to determine whether the English have a right to trade in Iceland would be "monstrous and absurd." 36 Eng. Rep. at 993.

For a discussion comparing the more expansive use of the doctrine in the United States with its more limited use in Great Britain, see Buttes Gas \& Oil Co. v. Hammer, [1975] 1 Q.B. 557, 572-74, 578-79 (opinions of Lord Denning, M.R., and Roskill, L.J.).

24 For a concise historical discussion tracing the common origin of the two doctrines, see Comment, Act of State and Sovereign Immunities Doctrines: The Need to Establish Congruity, 17 U.S.F. L. REv. 91, 93-94 (1982); see also First Nat'l City Bank v. Banco Nacional de Cuba, 406 U.S. 759, 762 (1972) (plurality opinion) (noting the common origin of the doctrines).

${ }^{23}$ See Hill, A Policy Analysis of the American Law of Foreign State Immunity, 50 FordhaM L. Rev. 155, 159 (1981).

${ }^{26}$ See Comment, supra note 24, at 93.

27 See id. at 93-94.

28 See M. AkeHurst, A Modern InTRODUction to INTERnational LAw 117 (5th ed. 1984); Note, Rehabilitation and Exoneration, supra note 2, at 600-10. For recent cases recognizing this origin of the act of state doctrine, see Allied Bank Int'l v. Banco Credito Agricola de Cartago, 757 F.2d 516, 520 (2d Cir. 1985) (noting that the act of state doctrine was "[o]riginally linked with principles of sovereign immunity"), and Libra Bank Ltd. v. Banco Nacional de Costa Rica, 570 F. Supp. 870, 876 (S.D.N.Y. 1983) (stating that early cases viewed the doctrine as "rooted in principles of sovereign immunity").

${ }^{29}$ See 11 U.S. (7 Cranch) at 136. 
nandez. ${ }^{30}$ The defendant in Underhill was a Venezuelan general who had taken over the Venezuelan government by force. An American citizen in Venezuela, alleging that the general had caused him damages immediately after the takeover, brought suit in the United States. ${ }^{31}$ In affirming judgment for the defendant, Chief Justice Fuller held that the general, as head of the de facto Venezuelan government, could not be held civilly responsible for his treatment of the plaintiff. ${ }^{32}$ The Chief Justice referred to the "immunity of individuals from suits brought in foreign tribunals for acts done within their own States, in the exercise of governmental authority." ${ }^{\text {33 }}$ Thus, in line with the original formulation of the act of state doctrine as a corollary to sovereign immunity, the Supreme Court emphasized that the general's acts were allegedly committed while he was serving in a governmental capacity. ${ }^{34}$

In the course of his opinion, however, Chief Justice Fuller made a statement that seemed to extend the scope of the doctrine beyond the personal immunity rationale. This statement, completely unnecessary to the disposition of the case, ${ }^{35}$ unfortunately is repeated today in almost every case involving the act of state doctrine:

Every sovereign State is bound to respect the independence of every other sovereign State, and the courts of one country will not sit in judgment on the acts of the government of another done within its own territory. Redress of grievances by reason of such acts must be obtained through the means open to be availed of by sovereign powers as between themselves. ${ }^{38}$

Now referred to as either the "classic American statement"s7 or the "traditional formulation" 38 of the act of state doctrine, this dictum de-

so 168 U.S. 250 (1897).

31 Id. at 250-51.

32 See id. at 253-54.

${ }^{33}$ Id. at 252.

34 See id. at 253-54.

35 Since the Court's decision rested on grounds of personal immunity, this additional discussion was superfluous. See Zander, supra note 2, at 830 (characterizing this language as dictum).

${ }^{36}$ Underhill, 168 U.S. at 252. Chief Justice Fuller's statement was not entirely original; the critical language comes from an earlier New York case, Hatch v. Baez, 14 N.Y. Sup. Ct. 596 (App. Div. 1876), in which the court stated that "the courts of one country are bound to abstain from sitting in judgment on the acts of another government done within its own territory." Id. at 599; see also Zander, supra note 2, at 829 (characterizing this language as "much wider than the case required").

${ }^{37}$ Banco Nacional de Cuba v. Sabbatino, 376 U.S. 398, 416 (1964), quoted in First Nat'l City Bank v. Banco Nacional de Cuba, 406 U.S. 759, 763 (1972); Comment, supra note 24 , at 96 n. 45 .

${ }_{38}$ Alfred Dunhill of London, Inc. v. Republic of Cuba, 425 U.S. 682, 691 n.7 
tached the doctrine from its personal immunity moorings and allowed it to drift into uncharted territory. ${ }^{30}$

Following Underhill, the Supreme Court began to invoke the act of state doctrine to dispose of cases on grounds having nothing to do with the personal immunity of foreign officials. The term was soon used in connection with the territorial principle of choice of law, which in the past accorded final authority to sovereigns over disputes occurring within their domains. The rationale for this principle stemmed from the theory, no longer accepted today, that only the territorial sovereign can create legal rights for persons within its territory. ${ }^{40}$ This theory was the basis for the decision in American Banana Co. $v$. United Fruit Co., ${ }^{41}$ a 1909 antitrust case dealing with the extraterritorial effect of United States antitrust laws. In American Banana, Justice Holmes held that despite the antitrust laws' seeming application to conduct outside of the United States, the laws do not apply to "[a] conspiracy in this country to do acts [unlawful in this country] in another jurisdiction . . . if they are permitted by the local law."42

The same rationale accounts for the 1918 decisions in Oetjen $v$. Central Leather Co. ${ }^{43}$ and Ricaud v. American Metal Co. ${ }^{44}$ These cases involved disputes over goods that were seized in Mexico by the Mexican revolutionary government and were later transported into the United States. In order to determine the rightful owner of the goods, the Supreme Court had to decide whether the governmental seizure was lawful. The Court refused to determine the validity of the seizure, however, because it was effected in a foreign territory by a government legally recognized by the United States. ${ }^{45}$ Once again applying choice of law analysis, the Court based its abstention on the grounds that the legality of the acts of a recognized foreign state is governed exclusively

(1976); Ramirez de Arellano v. Weinberger, 745 F.2d 1500, 1533 (D.C. Cir. 1984) (en banc), vacated mem., 105 S. Ct. 2353 (1985). Senator Mathias disapproves of both terms. See Mathias, supra note 2, at 372.

39 Senator Mathias characterizes the holding of Underhill as an "amalgam of 19th-century notions of recognition, of sovereign immunity and of mutual respect among sovereigns [in which] later jurists perceived a 'formulation' of the act of state doctrine." Mathias, supra note 2, at 372-73.

to See Cuba R.R. v. Crosby, 222 U.S. 473, $478-79$ (1912); American Banana Co. v. United Fruit Co., 213 U.S. 347, 356 (1909); see also Schlesinger, A Recurrent Problem in Transnational Litigation: The Effect of Failure to Invoke or Prove the Applicable Foreign Law, 59 CoRNELL L. REv. 1, 7 (1973) (noting that Justice Holmes was the major proponent of this now-discarded "vested rights" theory).

11213 U.S. 347 (1909).

$42 I d$. at 359.

43246 U.S. 297 (1918).

4246 U.S. 304 (1918).

15 See Oetjen, 246 U.S. at 302-04; Ricaud, 246 U.S. at 310. 
by the laws of that state. ${ }^{46}$

In Oetjen, the Supreme Court stated another rationale for the act of state doctrine:

The principle that the conduct of one independent government cannot be successfully questioned in the courts of another . . . rests at last upon the highest considerations of international comity and expediency. To permit the validity of the acts of one sovereign state to be reëxamined and perhaps condemned by the courts of another would very certainly "imperil the amicable relations between governments and vex the peace of nations." 47

From the beginning, therefore, the Supreme Court obscured the exact scope and meaning of the doctrine, using the same term-act of state-to signify three different reasons for judicial abstention: providing personal immunity to officials of foreign governments, preserving territorial choice of law, and avoiding international strife.

The modern act of state doctrine emerged from a trilogy of Supreme Court cases decided between 1964 and 1976, ${ }^{48}$ each dealing with the nationalization of American assets by Cuba in the aftermath of the

46 Professor John Bassett Moore, a former judge of the Permanent Court of International Justice, long ago criticized the reasoning of these cases:

By no law, national or international, can such a statement be justified; nor could any statement more vividly exemplify certain erroneous impressions lately prevailing. The supposition that recognition of any kind "validates all the actions and conduct" of the government recognized is as startling as it is novel. Recognition "validates" nothing. On the contrary, it opens the way to the diplomatic controversion of the validity of any and all "actions and conduct" that may be regarded as illegal. In the case of governments, just as in the case of men and women, the recognition of the existence of an individual entity does not imply, either retrospectively or prospectively, that its acts are legal.

Moore, The New Isolation, 27 AM. J. INT'L L. 607, 618 (1933) (quoting Oetjen, 246 U.S. at 303).

47246 U.S. at 303-04 (quoting Underhill v. Hernandez, 65 F. 577, 579 (2d Cir. 1895), aff d, 168 U.S. 250 (1897)).

18 Between 1918 and 1964 no significant act of state case was decided, and the doctrine was cited only sporadically by the courts. See, e.g., United States v. Belmont, 301 U.S. 324, 327-28 (1937) (Underhill, Oetjen, and Ricaud prevent examination of expropriations by the new Soviet government.); Shapleigh v. Mier, 299 U.S. 468, 471 (1937) (Mexican land expropriation decree must be recognized as valid under those same cases.). This time period marked the emergence of the doctrine of sovereign immunity within the context of trade and commerce. See Lillich, The Proper Role of Domestic Courts in the International Legal Order, 11 VA. J. INT'L L. 9, 18-27 (1970). It was this doctrine, rather than the act of state doctrine, that courts increasingly began to use in order to avoid reaching the merits of international transaction cases. See Berizzi Bros. Go. v. The Pesaro, 271 U.S. 562, 571-73 (1926) (recognizing theory of "absolute" sovereign immunity in the United States). 
Cuban revolution. ${ }^{49}$ These three cases, together with the above-quoted language from Underhill and Oetjen, make up the whole of the Supreme Court's guidance on the doctrine.

The first and most widely applied case of the three is Banco $\mathrm{Na}$ cional de Cuba v. Sabbatino, ${ }^{\text {so }}$ in which the Court was still speaking with more or less one voice on the doctrine. In Sabbatino, the legal controversy arose from Cuba's nationalization of American sugar interests. Banco Nacional de Cuba, the financial agent of the Cuban government, sued in federal district court in New York to recover proceeds from the sale of a sugar shipment that had been sold by an American company shortly before the company was nationalized by Cuba. The district court denied Banco Nacional's claim to the sugar proceeds because the Cuban nationalization decree was retaliatory, discriminatory, and confiscatory, and therefore violated international law. ${ }^{\text {k1 }}$ Most importantly, the district court held that, because of the violation of international law, its examination of the validity of the decree was not barred by the act of state doctrine. ${ }^{52}$

The Second Circuit upheld the district court's decision but based its refusal to apply the act of state doctrine on narrower grounds. ${ }^{53}$ The court relied on the Bernstein exception to the act of state doctrine, which requires courts to follow the will of the Executive when the State Department informs the court that the doctrine should not be applied. ${ }^{.4}$ In Sabbatino two letters-written by State Department officers while the case was on appeal-led the court to conclude that the Executive

40 "Some forty years after the doctrine's first pronouncement by Ghief Justice Fuller in Underhill v. Hernandez, the Cuban revolution and the legal disputes arising from those events led the Supreme Court to rethink the doctrine." Libra Bank Ltd. v. Banco Nacional de Costa Rica, 570 F. Supp. 870, 876 (S.D.N.Y. 1983) (tracing the history of the act of state doctrine).

so 376 U.S. 398 (1964). Professor Lillich describes Sabbatino as "undoubtedly one of the most important international law cases to be decided by a domestic court [in] this century." Lillich, supra note 48 , at 29.

s1 See Banco Nacional de Cuba v. Sabbatino, 193 F. Supp. 375, 384-85 (S.D.N.Y. 1961), affd on other grounds, 307 F.2d 845 (2d Cir. 1962), rev'd, 376 U.S. 398 (1964). For a critical discussion of the district court's opinion in Sabbatino by a proponent of the act of state doctrine, see R. FALK, supra note 4, at 77-114. See also infra note 58 (discussing Falk's thesis).

s2 See 193 F. Supp. at 381.

s3 Banco Nacional de Cuba v. Sabbatino, 307 F.2d 845, 857-58 (2d Cir. 1962), rev'd, 376 U.S. 398 (1964).

os See infra notes 270-77 and accompanying text (discussing the exception first enunciated in Bernstein v. N.V. Nederlandsche-Amerikaansche Stoomvaart-Maatschappij, 210 F.2d 375, 376 (2d Cir. 1954)). For analysis of the Second Circuit's Sabbatino opinion, see R. FALK, supra note 4, at 115-38; Lillich, A Pyrrhic Victory at Foley Square: The Second Circuit and Sabbatino, 8 Vil.. L. REv. 155 (1963); Stevenson, The Sabbatino Case-Three Steps Forward and Two Steps Back, 57 AM. J. INT'L L. 97 (1963). 
had no objection to a decision on the merits. ${ }^{.55}$

The Supreme Court, in an opinion written by Justice Harlan, reversed the lower courts. In a wide-ranging and sometimes confusing ${ }^{56}$ discussion of the act of state doctrine, the Court rejected the district court's conclusion that a United States court can pass judgment on a foreign state's local act when that act was committed in violation of international law. ${ }^{57}$ The Court refused to examine the validity of Cuba's expropriation because of what it perceived to be uncertainty in the applicable standards of international law. ${ }^{58}$ Following the language of Underhill, Justice Harlan stated that "the Judicial Branch will not examine the validity of a taking of property within its own territory_by a foreign sovereign government . . . in the absence of a treaty or other unambiguous agreement regarding controlling legal principles, even if

Bs See 307 F.2d at 857-58.

B8 Subsequent lower court decisions evidence a considerable lack of agreement about Sabbatino. See infra text accompanying notes 111-223. For incisive criticism of the Supreme Court's opinion, see Kline, An Examination of the Competence of $\mathrm{Na}$ tional Courts to Prescribe and Apply International Law: The Sabbatino Case Revisited, 1 U.S.F. L. REv. 49, 54-100 (1966); Lillich, supra note 48, at 31-34.

s7 See Sabbatino, 376 U.S. at 427-37.

68 See id. at 428-29. Justice Harlan's notion-that a domestic court should avoid deciding a case involving an issue of international law if there is insufficient international consensus about the proper resolution of the issue-is based on a thesis presented by Professor Falk while Sabbatino was making its way to the Supreme Court. See R. FALK, supra note 4, at 64-114; Falk, Toward a Theory of the Participation of Domestic Courts in the International Legal Order: A Critique of Banco Nacional de Cuba v. Sabbatino, 16 RutGers L. REv. 1 (1961). Professor Lillich, in his foreword to Falk's book, comments that Justice Harlan in Sabbatino adopted Falk's analysis "lock, stock and barrel." Lillich, supra note 5 , at vii.

Falk's defense of the act of state doctrine is based in part on the following premise: "[I]n general, municipal courts should avoid interference in the domestic affairs of other states when the subject matter of disputes illustrates a legitimate diversity of values on the part of two national societies." R. FALK, supra note 4, at 72. In those instances, disputes should be resolved either through "diplomatic pressure" or "supranational review." Id. at 106. Falk argues that judicial deference in such instances would lead to a stronger and more prestigious international legal order, since (1) domestic courts would cease to participate in the Cold War and other political rivalries, (2) such political rivalries would be decided by diplomacy or through supranational forums, and (3) domestic courts could promote the international legal order in areas in which a global consensus already exists. See id. at 112-14.

While extensive analysis of Falk's thesis is beyond the purview of this Article, it is worth noting two distinct problems with his approach. First, in the 20 years since the publication of Falk's thesis it has become apparent that supranational forums, such as the United Nations and the International Court of Justice, will not adequately develop international law. See infra notes 336-50 and accompanying text. Thus, greater reliance must be placed on a more active domestic judiciary. Second, neither Falk nor the Sabbatino Court specified the level of uncertainty in international law sufficient to justify judicial abstention. As a result, lower federal courts have avoided decisions on the merits even when there was an international consensus greater than that addressed by the Court in Sabbatino.

For additional criticism of Falk's thesis, see Kline, supra note 56, at 81-93. 
the complaint alleges that the taking violates customary international law." 59 The opinion suggested that in some circumstances American courts could determine the validity of such an act, but that such a determination could be made only on a case-by-case basis, taking into account "[t]he balance of relevant considerations."

In a later portion of his opinion, however, Justice Harlan offered broad dicta regarding the "constitutional underpinnings" of the act of state doctrine and the possibility of "embarrassment to the executive branch" from judicial interpretation of international law. ${ }^{61}$ Although Justice Harlan's holding was limited to expropriations, lower courts have seized upon these broad ruminations as a mandate to dismiss cases involving a wide variety of foreign transactions having nothing to do with expropriations. ${ }^{62}$ The formulation found in the early part of the

s9 Sabbatino, 376 U.S. at 428 . Underhill's "classic statement" was modified by Justice Harlan to permit judicial scrutiny of a foreign taking when a treaty or or other unambiguous international agreement supplies a controlling legal standard. This caveat in Sabbatino has been labeled the "treaty exception" to the act of state doctrine. See infra text accompanying notes 283-92.

6o Sabbatino, 376 U.S. at 428.

61 Id. at 432. The argument that courts must not decide cases if the decision would interfere with the Executive's control over foreign relations-a widely cited rationale for the act of state doctrine-serves to justify the courts' blind adherence to the Executive's views on whether the doctrine should be applied. This deference in effect suspends the constitutionally mandated separation of powers. See infra text accompanying notes 304-09.

In other contexts, however, courts regularly decide cases having potential foreign policy implications without considering the views of the Executive. The most glaring example is the law of extradition. The United States, by international custom, will not grant extradition in the absence of a bilateral treaty between the United States and the nation seeking extradition (commonly known as the "requesting nation"). Under United States practice, a federal court, not the Executive, decides whether to honor the request. The court's role is to interpret the extradition treaty, in effect applying international law, to determine whether the offense for which the defendant is sought is an extraditable one under the treaty. Even if the offense is extraditable, the court may still deny extradition if it finds that the defendant had political motives for committing the crime.

An extradition decision, of course, may have a significant effect on the foreign relations of the United States. If the court fails to grant extradition, relations between the United States and the requesting nation may suffer. Allowing extradition also may interfere with the Executive's ability to conduct effective foreign policy. Nevertheless, extradition decisions are consistently made by the judiciary without blind adherence to the Executive's wishes. If it is reasonable for courts to apply international law to resolve the sensitive issues that arise in extradition cases, then they should be able to do so in other international controversies as well.

For a good discussion of the international law of extradition and its application both in the United States and abroad, see J. SweEney, C. Oliver \& N. LeEch, The INTERNATIONAL Legal SysteM 138-44 (2d ed. 1981); Sutherland, The Development of International Law of Extradition, 28 Sr. Louis U.L.J. 33 (1984).

62 See, e.g., DeRoburt v. Gannett Co., 733 F.2d 701, 703 (9th Cir. 1984) (libel), cert. denied, 105 S. Ct. 909 (1985); Clayco Petroleum Corp. v. Occidental Petroleum Corp., 712 F.2d 404, 406 (9th Gir. 1983) (bribery), cert. denied, 464 U.S. 1040 
opinion-requiring case-by-case "balanc[ing] of relevant considerations"-is not cited nearly as often in lower court opinions as the simpler and broader formulation, taken by Justice Harlan from the dictum in Underhill, that "the courts of one country will not sit in judgment on the acts of the government of another done within its own territory."

The next two cases in the trilogy show that Sabbatino, with its multitude of pronouncements on the act of state doctrine, did not provide a clear standard for application of the doctrine in future cases. First National City Bank v. Banco Nacional de Cuba ${ }^{64}$-decided in 1972 and commonly referred to as Citibank-also involved an expropriation. The Guban government seized Citibank branches in Cuba. In retaliation, Citibank sold collateral securing a loan that it had made to a predecessor of Banco Nacional de Cuba. Banco Nacional then brought suit to recover the excess proceeds, and Citibank counterclaimed seeking to recover damages from the expropriation. Citibank conceded that the proceeds from the sale of the collateral exceeded the amount of remaining principal and unpaid interest, but it asserted by way of setoff that it had a right to keep the excess to compensate for the confiscation of its property in Cuba. ${ }^{65}$ Banco Nacional asserted the act of state doctrine as a defense to Citibank's counterclaim. ${ }^{68}$

As in the Sabbatino litigation, the lower courts in Citibank issued confusing statements on the act of state doctrine. The district court found that Sabbatino would have been controlling but for congressional actions taken since Sabbatino was decided. ${ }^{67}$ The court focused in particular on the Hickenlooper amendment to the Foreign Assistance Act of $1964,{ }^{68}$ which explicitly permitted the courts, notwithstanding the act of state doctrine, to reach the merits of cases involving confiscations by a foreign state. ${ }^{68}$ The court found that this amendment had "for all

(1984); International Ass'n of Machinists v. OPEC, 649 F.2d 1354, 1359 (9th Cir. 1981) (antitrust), cert. denied, 454 U.S. 1163 (1982); Frolova v. Union of Soviet Socialist Republics, 558 F. Supp. 358, 363 (N.D. Ill. 1983) (human rights), affd, 761 F.2d 370 (7th Cir. 1985); MOL, Inc. v. People's Republic of Bangladesh, 572 F. Supp. 79,83 (D. Or. 1983) (commercial exportation of rhesus monkeys), affd, 736 F.2d 1326 (9th Cir. 1984), cert. denied, 105 S. Ct. 513 (1984); Phoenix Canada Oil Co. v. Texaco Inc., 560 F. Supp. 1372, 1381 (D. Del. 1983) (oil concession dispute).

63 Sabbatino, 376 U.S. at 416.

406 U.S. 759 (1972).

65 Id. at $760-61$.

${ }^{68} \mathrm{Id}$. at 761 .

${ }^{87}$ Banco Nacional de Cuba v. First Nat'I City Bank, 270 F. Supp. 1004, 1007 (S.D.N.Y. 1969), rev'd, 431 F.2d 394 (2d Cir. 1970), vacated, 400 U.S. 1019 (1971). ${ }_{68}$ Pub. L. No. 88-633, § 301(d)(4), 78 Stat. 1009, 1012-13 (1964) (current version at 22 U.S.C. $\S 2370(\mathrm{e})(2)(1982))$.

69 Id. 
practical purposes" overruled Sabbatino. ${ }^{70}$ The Second Circuit, on the other hand, found that the Hickenlooper amendment was not dispositive $^{71}$ and that Sabbatino barred a decision on the merits of Citibank's counterclaim. ${ }^{\mathbf{2}}$

The Supreme Court reversed the Second Circuit and held that the act of state doctrine did not foreclose a decision on the merits. ${ }^{73}$ Justice Rehnquist, in a plurality opinion joined by Chief Justice Burger and Justice White, focused on a letter from the Legal Advisor of the Department of State. This letter informed the Court of the Department's " "belie[f] that the act of state doctrine should not be applied to bar consideration of a defendant's counterclaim or set-off against the Government of Cuba in this or like cases." "7t Justice Rehnquist found this directive from the Executive sufficient to prevent application of the act of state doctrine. While he referred to the separation of powers argument of Sabbatino as the rationale for the doctrine-implying that abstention from cases involving an act of state is a constitutional imperative $^{75}$-he stated later in the opinion that the only purpose of the doctrine was to prevent embarrassment to the executive branch. ${ }^{76}$ In light of this purpose, he reasoned, when the Executive indicates that the act of state doctrine should not be applied, as it had done in the case at bar, the Court should automatically defer to the Executive's wishes and find the act of state doctrine inapplicable. ${ }^{77}$ This is the Bernstein exception to the act of state doctrine, ${ }^{78}$ which, Justice Rehnquist said,

70270 F. Supp. at 1007.

71 See Banco Nacional de Cuba v. First Nat'l Gity Bank, 431 F.2d 394, 399-402 (2d Cir. 1970), vacated, 400 U.S. 1019 (1971). The Second Gircuit issued two separate opinions in this case. It first reversed the district court, see id., but the Supreme Court on appeal remanded the case to the Second Circuit for reconsideration in light of the State Department's statements about the case. See 400 U.S. at 1019. On remand, the Second Circuit again decided to reverse the district court. See Banco Nacional de Cuba v. First Nat'l City Bank, 442 F.2d 530, 532 (2d Cir. 1971), rev'd, 406 U.S. 759 (1972).

${ }^{72}$ See 431 F.2d at 394-95.

73 See Citibank, 406 U.S. at 770 . The five Justices who agreed with the result, however, could not agree on the reasons why the act of state doctrine should not be applied. See infra notes 74-88 and accompanying text.

${ }^{74}$ Citibank, 406 U.S. at 764 (quoting letter from State Department). The full text of the State Department's letter is appended to the Second Circuit's second Citibank opinion. See 442 F.2d at 536-38.

${ }^{75}$ See Citibank, 406 U.S. at 765-67.

${ }^{76}$ See id. at 769-70.

77 See id. According to Justice Rehnquist, "[T]his [is] no more than an application of the classical common-law maxim that " $t$ t]he reason of the law ceasing, the law itself also ceases." Id. at 768 (quoting Black's LAw Dictionary 288 (4th ed. 1941)).

78 See infra notes $270-77$ and accompanying text. 
"we of course adopt and approve."79

As the plurality decision in Citibank makes clear, the difference between the results in Sabbatino and Citibank, which both concerned Cuban expropriations, is primarily attributable to the different positions taken by the Executive in the two cases. ${ }^{80}$ In Sabbatino, the Solicitor General filed an amicus brief before the Supreme Court in which he argued that the act of state doctrine should be applied in that case. ${ }^{81}$ Conversely, in Citibank, the State Department wrote a letter urging the Court to refrain from applying the doctrine. ${ }^{82}$

Only Chief Justice Burger and Justice White, however, accepted Justice Rehnquist's proposition that the Executive may, at its option, determine whether a court will adjudicate a controversy. Justice Douglas preferred to rely on the equitable argument that "fair dealing requires allowance of the setoff to the amount of the claim on which this suit is brought." but explicitly rejected the positions of Justices Rehnquist and Douglas. ${ }^{84}$ In Justice Powell's view, the courts have a duty to hear all cases like Citibank"[u]nless it appears that an exercise of jurisdiction would interfere with delicate foreign relations conducted by the political branches." ${ }^{85}$ Thus, Justice Powell concurred in the judgment of $\mathrm{Ci}$ tibank not because the Executive gave its "permission," 86 but because on the Citibank facts he saw no conflict between the political and judicial branches. ${ }^{87}$ Justice Powell also expressed his displeasure with the "broad holding of Sabbatino," which, he stated, "was not compelled by the principles ... which underlie the act of state doctrine." 88

In a strongly worded dissent, Justice Brennan, joined by Justices Stewart, Marshall, and Blackmun, refused to recognize the Bernstein exception. According to Justice Brennan, to do so would be to abdicate the courts' role in enforcing the separation of powers and to allow

${ }^{79}$ Citibank, 406 U.S. at 768.

so See Citibank, 406 U.S. at 764-65, 767.

B1 See infra notes 229-31 and accompanying text.

82 See Citibank, 406 U.S. at 764.

83406 U.S. at 772 (Douglas, J., concurring in the result) (citing National City Bank v. Republic of China, 348 U.S. 356, 365 (1955)). The force of Justice Douglas's argument did not go unnoticed by Justice Rehnquist, who felt compelled, at the end of his plurality opinion, to comment that "the result we reach is consonant with . . . [Republic of China]." 406 U.S. at 768.

8s See Citibank, 406 U.S. at 775 (Powell, J., concurring in the judgment).

ss Id.

so "I would be uncomfortable with a doctrine which would require the judiciary to receive the Executive's permission before invoking its jurisdiction." Id. at 773 .

87 See id. at 776.

${ }^{88} I d$. at 774 (footnote omitted). 
politics, not law, to dictate judicial results. ${ }^{89} \mathrm{He}$ asserted that even a "cursory" reading of Sabbatino belied Justice Rehnquist's view that the act of state doctrine functions only to prevent embarrassment to the Executive. ${ }^{90}$ Instead, Justice Brennan argued, the doctrine compels judicial abstention for reasons related to the political question doctrine, and the potential of embarrassment to the Executive is merely one-and not necessarily the most important-factor evidencing the existence of a "political question."

To Justice Brennan, therefore, the political question doctrine and the act of state doctrine are ultimately equivalent. Justice Brennan even attributed this view to Sabbatino, although Justice Harlan's opinion did not make that formulation. ${ }^{92}$ Justice Brennan also did not explain why the act of state doctrine is necessary at all if cases can be resolved through the political question doctrine.

The fractured opinion in Citibank offers little guidance to lower federal courts. Three Justices-Burger, White, and Rehnquistwanted to follow Sabbatino, as limited by the Bernstein exception. One Justice-Powell-was ready to reject Sabbatino. Four other justicesBrennan, Stewart, Marshall, and Blackmun-wanted to adopt a new approach that equated the act of state doctrine with the political question doctrine, but they did not explain why the act of state doctrine then needed to be discussed. Six Justices-Douglas, Brennan, Stewart, Marshall, Blackmun, and Powell-had doubts about the applicability of the Bernstein exception, even though the State Department had written a letter to the Court asking that the case be adjudicated. Five of those Justices-all but Douglas-rejected the Bernstein exception outright. Citibank perfectly illustrates the widespread disagreement and confusion that exists in the Supreme Court (and lower federal courts) regarding the act of state doctrine.

The trilogy ends with Alfred Dunhill of London, Inc. v. Republic of Cuba, ${ }^{93}$ decided in 1976. In Dunhill, the Court again was unable to muster a majority view for a particular application of the act of state

s9 See Citibank, 406 U.S. at 790-93 (Brennan, J., dissenting).

80 See id. at 785 .

91 See id. at 787-88. The other factors pointed out by Justice Brennan were

the absence of consensus on the applicable international rules, the unavailability of standards from a treaty or other agreement, the existence and recognition of the Cuban Government, the sensitivity of the issues to national concerns, and the power of the Executive alone to effect a fair remedy for all United States citizens who have been harmed.

Id.

${ }^{92}$ See id. at 787-88.

9s 425 U.S. 682 (1976). 
doctrine; as a result, no single rule or guideline emerged from the case. The Court in Dunhill considered, but did not conclusively determine, the validity of another exception to the act of state doctrine-the socalled "commercial exception."

The proceedings in Dunhill grew out of the Cuban government's nationalization of five privately owned cigar manufacturers. After the nationalization, "interventors" named by the Cuban government to take control of the seized Cuban concerns continued to ship cigars to American importers, including Dunhill. The former owners of the Cuban companies, most of whom had fled to the United States following the expropriation, sued Dunhill in federal district court for trademark infringement and for the value of the cigars that the interventors had sold to Dunhill. The issue in the case was whether the act of state doctrine was implicated by the interventors' refusal to reimburse the importers for sums that the importers had paid to the interventors rather than the former owners. ${ }^{94}$

As in the previous cases in the trilogy, the lower federal courts could not agree on the application of the doctrine. The district court refused to apply the doctrine, ${ }^{95}$ while the court of appeals held that the doctrine applied to a portion of the debt. ${ }^{98}$

The Supreme Court again was unable to come up with a majority view on an important issue connected with the act of state doctrine. By a five to four vote, the Court refused to apply the doctrine on the narrow grounds that no act of state had been proven, since the interventors had not shown that their repudiation was a "public act of those with authority to exercise sovereign powers." The Court's judgment was based on two narrow propositions: (1) the interventors had the burden of proving that their actions were acts of state; and (2) the evidence submitted by the interventors was insufficient to satisfy this burden. ${ }^{98}$

The Court's agreement was limited to these two propositions. While Justice White's plurality opinion stated that "[w]e decline to ex-

94 See id. at 685-88.

9s See Menendez v. Faber, Coe \& Gregg, Inc., 345 F. Supp. 527 (S.D.N.Y. 1972), modified sub nom. Menendez v. Saks \& Co., 485 F.2d 1355 (2d Cir. 1973), rev'd sub nom. Alfred Dunhill of London, Inc. v. Republic of Cuba, 425 U.S. 682 (1976).

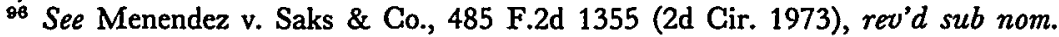
Alfred Dunhill of London, Inc. v. Republic of Cuba, 425 U.S. 682 (1976).

${ }_{97}$ Dunhill, 425 U.S. at 694. In arguing for the plaintiff in Frolova v. Union of Soviet Socialist Republics, 558 F. Supp. 358 (N.D. Ill. 1983), affd, 761 F.2d 370 (7th Cir. 1985), Professor Anthony D'Amato, a noted international legal scholar, asserted that Dunhill abolished the act of state doctrine. See id. at 363. The court strongly disagreed with him on this point, stating that "[t]he majority in Dunhill expressed no doubt as to the [doctrine's] continuing validity." $I d$.

${ }^{98}$ See Dunhill, 425 U.S. at 691-95. 
tend the act of state doctrine to acts committed by foreign sovereigns in the course of their purely commercial operations," Justices-Burger, Powell, and Rehnquist-agreed with this proposition; ${ }^{100}$ a majority of the Court declined to endorse this "commercial exception" to the act of state doctrine. ${ }^{101}$

Justice Marshall wrote a dissenting opinion joined by Justices Brennan, Stewart, and Blackmun. The dissenters disagreed with the majority's conclusion that, because " '[n]o statute, decree, order or resolution of the Cuban Government itself was offered in evidence," "102 the expropriation was not an act of state. Justice Marshall argued that an act of state need not take any particular form ${ }^{103}$ and could include even the passive conduct represented by the "interventors' retention of and a refusal to return funds paid to them by Dunhill."104 $\mathrm{He}$ also disagreed with Justice White's recognition of a commercial exception to the act of state doctrine. According to Justice Marshall, "The carving out of broad exceptions to the doctrine is fundamentally at odds with the careful case-by-case approach adopted in Sabbatino."105

In Dunhill, as in the other cases, the Supreme Court asked the State Department for its views on application of the act of state doctrine. In response, the State Department urged that Sabbatino be overruled and strongly intimated that the doctrine should be abolished. ${ }^{106}$ Ironically, as Justice Marshall pointed out in his dissent, ${ }^{107}$ when Sabbatino was before the Supreme Court the Executive urged just the opposite. ${ }^{108}$ This time, however, all of the Justices, including Justice Rehnquist, seem to have ignored the State Department's opinion. ${ }^{109}$

98 Id. at 706 .

100 See id. at 684.

101 Rejecting the commercial exception were Justices Brennan, Stewart, Marshall, Blackmun, and Stevens. Justice O'Connor, who replaced Justice Stewart, may now be the crucial "swing vote" in the Court's next act of state case.

102 Dunhill, 425 U.S. at 718 (Marshall, J., dissenting) (quoting Dunhill, 425 U.S. at 695).

103 See id. at 719-20.

104 Id. at 716.

${ }^{105}$ Id. at 728. Justice Marshall did not rule out the selective use of the commercial exception in future cases: "In the final analysis . . . it is unnecessary to consider whether the exception would be responsive to the concerns underlying the act of state doctrine in every case to which it might apply." Id. at 728-29 (footnote omitted).

${ }^{108}$ See id. at 696-98, 706-11; see also infra notes 237-41 and accompanying text. The State Department expressed this view in understated terms: "[I]t is our view that if the Court should decide to overrule the holding in Sabbatino so that acts of state would thereafter be subject to adjudication in American courts under international law, we would not anticipate embarrassment to the conduct of the foreign policy of the United States." Id. at 710-11.

107 See id. at 725 n.10 (Marshall, J., dissenting).

${ }^{108}$ See infra notes 229-31 and accompanying text.

109 Justice Rehnquist's response is, of course, inconsistent with his earlier opinion 
The Court retained the doctrine, although a majority of the Justices did find the doctrine inapplicable to the facts of Dunhill.

Such is the confused state of act of state doctrine in the Supreme Court. The Justices cannot agree on the meaning of the doctrine, on the role the Executive should play in its application by the courts, or on the status of the various exceptions to the doctrine. ${ }^{110}$ Not surprisingly, this disagreement in the Supreme Court is mirrored in the lower federal courts.

\section{B. The Act of State Doctrine in the Lower Federal Courts: Discord Among and Within the Circuits}

The Supreme Court, with its opinions primarily limited to cases it accepts by a grant of certiorari, has dealt with the act of state doctrine only in limited circumstances. The Sabbatino/Citibank/Dunhill trilogy, together with the older Oetjen and Ricaud cases, dealt with the doctrine in one factual setting: expropriations by foreign governments. The Underhill case involved the older act of state problem of governmental immunity. Thus, Supreme Court cases reveal only the tip of the iceberg of the act of state doctrine.

One of the most alarming aspects of the doctrine is the potential breadth of its application to American jurisprudence. ${ }^{111}$ The decisions of the lower federal courts illustrate that the act of state doctrine might be invoked whenever a claim arises that involves events outside of the United States. For example, many United States laws have an extraterritorial component. ${ }^{112}$ The act of state doctrine can prevent the rightful application of these laws outside of United States borders. ${ }^{113}$ The doctrine also can prevent the resolution of disputes between private parties doing business abroad. ${ }^{114}$ Since international business transactions are

in Citibank, in which he urged that the Executive's recommendations on the act of state doctrine be dutifully followed. See supra notes 73-79 and accompanying text.

110 This lack of consensus probably explains why for the last decade the Supreme Court, despite disagreement among the circuits, has consistently declined to review significant decisions on the act of state doctrine. cases).

${ }_{111}$ See, e.g., cases cited supra note 62 (illustrating the variety of act of state

112 On the extraterritorial effect of United States antitrust and securities laws, see infra notes 319-26 and accompanying text (antitrust laws); infra notes 327-29 and accompanying text (securities laws). On the extraterritorial effect of United States patent, trademark, and copyright laws, see Steele v. Bulova Watch Co., 344 U.S. 280, 283 87 (1952); American Rice, Inc. v. Arkansas Rice Growers Coop. Ass'n, 701 F.2d 408, 412-16 (5th Cir. 1983); Wells Fargo \& Co. v. Wells Fargo Express Co., 556 F.2d 406, 426-29 (9th Cir. 1977); Vanity Fair Mills v. T. Eaton Go., 234 F.2d 633, 641-43 (2d Cir.), cert. denied, 352 U.S. 871 (1956).

11 See infra notes 319-35 and accompanying text.

114 See, e.g., Clayco Petroleum Corp. v. Occidental Petroleum Corp., 712 F.2d 
becoming increasingly common, and since foreign governments usually have some involvement in these transactions, ${ }^{115}$ seemingly every international business dispute may be rendered nonjusticiable by the act of state doctrine. Unlike the doctrine of sovereign immunity, the act of state doctrine may be applied even if a foreign government is not a party in a case. ${ }^{116}$

In addition, the act of state doctrine undermines predictability, a primary goal in business transactions. When private parties do business with a foreign government, they can arrange contractually for the sovereign to waive the defense of sovereign immunity. ${ }^{117}$ The parties cannot, however, contractually preclude the later application of the act of state doctrine, since the court may apply the doctrine sua sponte. Thus, in international business transactions, the act of state doctrine presents a trap that-even if anticipated by the parties to the transaction-cannot necessarily be avoided.

While every federal circuit except the Tenth Gircuit has issued act of state opinions, some circuits have had a greater influence in shaping the doctrine. Because the Second Circuit includes New York, the center of international business, it has issued the most act of state opinions. ${ }^{118}$ The Ninth Circuit-which includes the West Coast international business centers, San Francisco and Los Angeles-has also issued important act of state pronouncements. In addition to opinions from these two circuits, an opinion from the Third Gircuit has received considerable attention. Finally, the District of Columbia Circuit recently issued a comprehensive act of state opinion that may be widely cited in the future.

404 (9th Cir. 1983); Hunt v. Mobil Oil Corp., 550 F.2d 68 (2d Cir.), cert. denied, 434 U.S. 984 (1977).

116 See authorities cited note 250 infra; cf. Dunhill, 425 U.S. at 703 ("Participation by foreign sovereigns in the international commercial market has increased substantially in recent years. The potential injury . . . from a system in which some of the participants in the international market are not subject to the rule of law has therefore increased correspondingly.") (citation omitted).

118 See The Law of Transnational Business Transactions 10-33 (V. Nanda ed. 1984).

117 See 28 U.S.C. $§ 1605$ (a)(1) (1982) (waiver of sovereign immunity under the Foreign Sovereign Immunities Act).

${ }_{18}$ A WESTLAW search in December 1985 (CTA database) using the search command "act of state doctrine" yielded 31 cases decided by the Second Circuit. Its closest competitor was the Fifth Circuit, with 22 cases. The Second Circuit's special influence spans the entire history of the doctrine in the United States. The first American act of state case was adjudicated in New York, see supra note 38, and the Supreme Court's three most recent act of state cases-Sabbatino, Citibank, and Dunhill-originated in the Second Circuit, specifically in the Southern District of New York. 


\section{The Second Circuit}

The best-known Second Circuit case discussing the act of state doctrine is Hunt v. Mobil Oil Corp. ${ }^{119}$ Hunt, an independent oil producer, alleged that Mobil and six other major oil companies conspired among themselves and with Libya to eliminate him as their competitor in Libya, in violation of United States antitrust laws. According to Hunt, the seven oil companies encouraged him not to negotiate with the Libyan government of Colonel Qadhafi concerning his oil concession in Libya. The oil companies allegedly knew that if he held firm against Libyan governmental pressure, Libya would nationalize his oil concession, thereby leaving the defendant oil companies to divide among themselves Hunt's former share of the market. ${ }^{120}$ Following Libya's expropriation of his assets, Hunt sought antitrust damages against the defendant oil companies under the Sherman Act and the Wilson Tariff Act. ${ }^{121}$

In his pleadings, Hunt neither directly challenged the validity of the Libyan government's action nor joined the Libyan government as a defendant. ${ }^{122}$ Nevertheless, the Second Circuit dismissed Hunt's claim on the basis of the act of state doctrine. The court found that in order to evaluate Hunt's claims properly it would need to examine the motives of the Libyan government in expropriating Hunt's concession. Since this would inevitably involve a determination of the validity of the Libyan act, the court held that the act of state doctrine required judicial abstention. ${ }^{123}$

119550 F.2d 68 (2d Cir.), cert. denied, 434 U.S. 984 (1977).

120 Id. at 70-72. "The efforts of the [Hunt] brothers to reach all parties possibly involved against their interests in oil from Libya have become litigation legend in their own time." J. SWEENEY, C. Oliver \& N. LEECH, supra note 61, at 406. For an account of the Hunt oil litigation, see Note, Sherman Act Jurisdiction and the Acts of Foreign Sovereigns, 77 Colum. L. REv. 1247, 1259-62 (1977).

${ }_{121}$ Hunt, $550 \mathrm{~F} .2 \mathrm{~d}$ at 70 (citing section 1 of the Sherman Act, 15 U.S.C. $\S 1$ (1982), and section 73 of the Wilson Tariff Act, 15 U.S.C. $\S 73$ (1982)).

122 See id. at 72-75.

12s See id. at 76-78. The broad and inflexible approach of Hunt has been criticized by other courts. See Williams v. Curtiss-Wright Corp., 694 F.2d 300, 304 n.5 (3d Cir. 1982); Compania de Gas de Nuevo Laredo, S.A. v. Entex, Inc., 686 F.2d 322, 325 (5th Cir. 1982), cert. denied, 460 U.S. 1041 (1983); Industrial Inv. Dev. Corp. v. Mitsui \& Co., 594 F.2d 48, 55 (5th Cir. 1979), cert. denied, 445 U.S. 903 (1980); Sage Int'l Ltd. v. Cadillac Gage Co., 534 F. Supp. 896, 902-08 (E.D. Mich. 1981). Even within the Second Circuit, some district courts have attempted to distinguish Hunt rather than follow its drastic approach. See, e.g., Rasoulzadeh v. Associated Press, 574 F. Supp. 854, 857-60 (S.D.N.Y. 1983).

Perhaps the most mechanical application of the Hunt rule occurred in DeRoburt v. Gannett Co., 733 F.2d 701 (9th Cir. 1984), cert. denied, 105 S. Ct. 909 (1985). Plaintiff DeRoburt was the elected president of Nauru, one of the Marshall Island republics. He sued Gannett, a newspaper company, for publishing an allegedly libelous 
The problem with the Hunt analysis is that in the great majority of international transaction cases a foreign sovereign has some cognizable ownership or regulatory interest. Since such cases inevitably must be resolved by examining the sovereign's motivations, the Hunt analysis precludes adjudication in the United States of most international transaction cases.

In Texas Trading $\&$ Milling Corp. v. Federal Republic of Nigeria, ${ }^{124}$ another panel of the Second Circuit took an entirely different view of the act of state doctrine. Texas Trading involved Nigeria's massive default in 1981 on its numerous international contracts to purchase cement. In contrast to Hunt, the foreign sovereign in Texas Trading, Nigeria, was itself the defendant in the case; moreover, in order to determine the legality of Nigeria's repudiation of the contract, the court had to examine Nigeria's motivations. The Second Circuit, however, in an opinion by Judge Kaufman, concluded in a single footnote that the act of state doctrine would not prevent adjudication of the dispute. $^{125}$ Curiously, to support his argument against application of the doctrine, Judge Kaufman cited Justice Marshall's argument that the doctrine should have been applied in Dunhill. ${ }^{126}$ Judge Kaufman took to heart Justice Marshall's call for a "careful case-by-case analysis of the extent to which the separation of powers concerns . . . are implicated by the action before the court"127 and determined that in this case application of the act of state doctrine would be inappropriate.

In the same year, the Second Circuit also decided Empresa Cubana Exportadora de Azucar y Sus Derivados v. Lamborn $\mathbb{E}$ Co. ${ }^{128}$ The Empresa Cubana panel, however, reverted to a more dogmatic approach to the act of state doctrine. ${ }^{129}$ Empresa Cubana was

article accusing him of making an illegal loan. Citing Hunt and its successor cases, the district court dismissed the suit on act of state grounds, finding that the lawsuit would inevitably require an analysis of DeRoburt's motivation in making the loan. This result is absurd: the sovereign in DeRoburt invited an examination of his motivations, thereby precluding any possibility of embarrassment to United States foreign relations. Since the potential for such embarrassment is the only reason why motivations of a foreign sovereign cannot be examined, this case did not present an appropriate occasion for applying the act of state doctrine.

${ }_{124} 647$ F.2d 300 (2d Cir. 1981), cert. denied, 454 U.S. 1148 (1982).

125 See id. at 316 n.38.

${ }_{126}$ See id. (citing Dunhill, 425 U.S. at 728 (Marshall, J., dissenting)).

${ }_{127}$ Id. Judge Kaufman took the same reasoned approach to the act of state doctrine in Associated Container Transp. (Austl.) v. United States, 705 F.2d 53, 62 (2d Cir. 1983), allowing a federal antitrust investigation to proceed despite objections by private foreign firms that the investigation amounted to questioning the validity of their sovereign governments' actions.

${ }_{128} 652$ F.2d 231 (2d Cir. 1981).

120 The American Bar Association issued a report in 1984 that proposed amending the Foreign Sovereign Immunities Act of 1976 (FSIA), 28 U.S.G. $\S \S 1330$, 
another case involving Cuba's expropriation of property owned by United States citizens. Lamborn was a sugar broker and a partner in Lamborn, Craig \& Co. (Craig). Acting as Craig's agent, Lamborn bought sugar from the predecessor in interest of Empresa Cubana, a company wholly owned by the Republic of Cuba. Five percent of the purchase price was still unpaid when the Cuban government seized Craig's assets; as in Dunhill, an interventor was appointed to administer the expropriation. The Republic of Cuba then initiated a suit against Lamborn, Craig's assignee, to recover the unpaid sums. After the district court permitted the Republic of Cuba to amend its complaint so as to substitute Empresa Cubana as plaintiff, Lamborn counterclaimed based on Cuba's expropriation. ${ }^{130}$

The district court held that the act of state doctrine prevented it from hearing Lamborn's counterclaim. ${ }^{131}$ The appellate court agreed, even though it acknowledged that Empresa Cubana's activities were wholly commercial in nature. ${ }^{\mathbf{1 3 2}}$ The court focused on the expropriation rather than on the parties' sugar transactions. Finding the expropriation to be a noncommercial act, the court held that the act of state doctrine prevented it from reviewing the merits of the parties' dispute. $^{138}$

Thus, in Empresa Cubana the Second Circuit seemed to follow both the broad formulations of the Hunt decision and the dissents in Dunhill and Citibank, all of which argued for abstention in cases involving expropriations by foreign governments. ${ }^{134}$

\section{The Ninth Circuit}

The Ninth Gircuit, like the Second Gircuit, has made conflicting statements regarding the act of state doctrine. Modern Ninth Gircuit

1332(a)(2)-(4), 1391(f), 1441(d), 1602-1611 (1982), to prevent the act of state doctrine from limiting the effectiveness of the FSIA. See infra text accompanying notes 406-10. That report cites Empresa Cubana as an example of a case that misapplied the doctrine. See Report on the Foreign Sovereign Immunities Act of 1976, 1984 A.B.A. SEC. INT'L L. PRAC. 2. For other critical analyses of the Empresa Cubana case, see Comment, supra note 24, at 107-10; Note, Limiting the Act of State Doctrine, supra note 2, at $118-20$.

130 See 652 F.2d at 233-34.

131 See $i d$. at 235.

192 See id. at 233, 237-38.

13s See id. at 238-39.

134 Curiously, Judge Kaufman was one of the judges on the Empresa Cubana panel. It is unclear how he could reconcile his narrow interpretation of the act of state doctrine in Texas Trading and Associated Container Transp. (Austl.) v. United States, 705 F.2d 53 (2d Cir. 1983), with his later accession to the much broader interpretation of the doctrine in Empresa Cubana. 
law on the doctrine was first enunciated in a 1976 case, Timberlane Lumber Co. v. Bank of America National Trust E Savings Association. ${ }^{195}$ Timberlane, an American milling manufacturer, sued Bank of America for allegedly entering into a conspiracy with the government of Honduras to ruin its operations in that country. ${ }^{138}$ Like the defendants in Hunt, Bank of America sought to use the act of state doctrine to prevent the court from hearing the case. The district court dismissed the case on act of state grounds, but the Ninth Circuit reversed. ${ }^{137}$

At the outset of its opinion, the Ninth Circuit made an important point about the doctrine: "It is apparent that the [act of state] doctrine does not bestow a blank-check immunity upon all conduct blessed with some imprimatur of a foreign government."138 With this in mind, the court then examined the conduct that Bank of America claimed called for abstention on act of state grounds. The court found that the conduct that Bank of America had characterized as an exercise of Honduran sovereignty consisted of judicial proceedings initiated against the plaintiff by a private party, not by the Honduran government. ${ }^{139}$ The court also noted that Timberlane did not name Honduras or any government official as a defendant. For these reasons, the court concluded that the lawsuit would not threaten relations with a foreign state. ${ }^{\mathbf{1 4 0}}$ According to the court, the touchstone of the act of state doctrine, as recognized in Sabbatino, is the potential for interference with American foreign policy. ${ }^{141}$ Since the court did not find a potential for such interference in this lawsuit, it ruled that the act of state doctrine was inapplicable. ${ }^{142}$ Thus, the Ninth Circuit in Timberlane took a flexible view of the act of state doctrine. First, the court made clear that there is less need

135549 F.2d 597 (9th Cir. 1976).

${ }^{138}$ See id. at 601.

${ }^{197} \mathrm{See}$ id. at 615. Timberlane's victory, however, was short-lived. When the case was remanded to the district court to determine whether the Sherman Act's extraterritorial provisions applied to the case, the district court held that they did not, and again dismissed the suit. The Ninth Gircuit affirmed the dismissal. See Timberlane Lumber Co. v. Bank of Am. Nat'l Trust \& Sav. Ass'n, 574 F. Supp. 1453 (N.D. Cal. 1983), affd, 749 F.2d 1378 (9th Cir. 1984). The Ninth Circuit did not mention the act of state doctrine in its affirmance; rather, it mechanically applied the factors listed in the first Timberlane decision for determining whether a foreign-based transaction should be subject to the Sherman Act. The court found that dismissal was warranted because a majority of those factors weighed against application of the Sherman Act to the Honduran events in Timberlane, even though both parties were American entities. See 749 F.2d at 1382-86. In effect, defendant Bank of America obtained through Sherman Act analysis what it could not obtain by means of the act of state doctrine.

188549 F.2d at 606.

139 See id. at 608 .

140 See id.

${ }^{141}$ See id. at 605-06.

142 See id. at 608. 
for application of the doctrine when the defendant is not the foreign sovereign itself, but only a private party having some involvement with the foreign sovereign. ${ }^{143}$ This distinction, of course, would likely reduce the frequency with which the act of state doctrine is applied in litigation involving foreign parties. Second, in contrast to American Banana and Sabbatino, the court did not even address the legality of the Honduran government's acts under local or international law. ${ }^{144}$ Third, although the Timberlane court included the need to examine the motivation of the sovereign as one factor in its analysis, the court did not treat this question as dispositive. ${ }^{145}$ Finally, the court took into account the importance of the United States' interest in enforcing extraterritorial applications of its antitrust laws. According to the Timberlane view, the courts should enforce such laws unless enforcement would damage the foreign relations of the United States. ${ }^{146}$

The flexible approach taken up by the Ninth Gircuit in Timberlane did not prevail long. In 1981, it was replaced by a more dogmatic approach, developed in International Association of Machinists (IAM) v. OPEC. ${ }^{147}$ The OPEC opinion presents a comprehensive discussion of the act of state doctrine, and for this reason remains one of the most widely cited act of state cases. ${ }^{148}$ Moreover, since the Supreme Court has not issued a decision on the act of state doctrine for almost ten years-since the 1976 Dunhill decision-the OPEC case has become, by default, the most recent detailed pronouncement on the doctrine. Unfortunately, OPEC is a good example of judicial misuse of the doctrine, and with its wide acceptance it is a major contributor to the existing confusion in this area.

In OPEC, IAM, a labor union, sued OPEG and its member nations for alleged violations of United States antitrust laws. Specifically, IAM claimed that OPEC's fixing of the world-wide prices of oil violated section one of the Sherman Act, and it sought monetary damages and injunctive relief under sections four and five of the Glayton Act. ${ }^{149}$

${ }^{143}$ See id.
${ }^{144}$ See id. at $605-08$.
${ }^{145}$ See id. at $606-08$.
${ }_{146}$ See id. at $613-15$.
${ }_{147} 649$ F.2d 1354 (9th Cir. 1981), cert. denied, 454 U.S. 1163 (1982).

148 Most act of state decisions today cite OPEC. See, e.g., Tel-Oren v. Libyan Arab Republic, 726 F.2d 774, 803, 818 (D.C. Cir. 1984), cert. denied, 105 S. Ct. 1354 (1985); Associated Containers Transp. (Austl.) v. United States, 705 F.2d 53, 61 (2d Cir. 1983); Sharon v. Time, Inc., 599 F. Supp. 538, 546-48 (S.D.N.Y. 1984).

149 See OPEC, 649 F.2d at 1355-56 (citing section one of the Sherman Act, 15 U.S.C. $\S 1$ (1982), and sections four and five of the Clayton Act, 15 U.S.C. $\S \S 15-16$ (1982)). For a discussion of the United States antitrust laws and their relationship to the act of state doctrine, see infra text accompanying notes 319-26. 
However, according to the OPEC court, IAM's lawsuit enmeshed the court in the world of petro-politics and thus presented it with a dilemma. If, on the one hand, the court declared the OPEC nations' price fixing to be illegal, the decision would amount to a "domestic court instructing a foreign sovereign to alter its chosen means of allocating and profiting from its own valuable natural resources,"150 which the court was unwilling to do. If, "[o]n the other hand, ... . the court [should] hold that OPEG's actions are legal, this 'would greatly strengthen the bargaining hand' of the OPEC nations in the event that Congress or the executive chooses to condemn OPEC's actions."151 Faced with the dilemma of how to avoid deciding the case, the federal district court and the Ninth Circuit took different routes.

The district court disposed of the case by stating that it lacked jurisdiction under the Foreign Sovereign Immunities Act of 1976 (FSIA). ${ }^{152}$ The FSIA governs the subject-matter jurisdiction of federal and state courts in actions against foreign sovereigns stemming from their commercial and private law activities. ${ }^{153}$ The district court reasoned that jurisdiction was lacking because OPEG's price fixing amounted to control over natural resources and thus was a public rather than a commercial function. ${ }^{154}$ However, the district court's analysis was incorrect. Under the FSIA, the test for determining whether an act is commercial is objective: it does not involve inquiry into the purpose of the act. ${ }^{185}$. Since the sale of oil on the worldwide market is a purely commercial activity, jurisdiction under the FSIA is clearly established, regardless of the activity's underlying public purpose.

On appeal, the Ninth Gircuit seemed to recognize the district

150 OPEC, 649 F.2d at 1361.

161 Id. (quoting Sabbatino, 376 U.S. at 432).

162 See International Ass'n of Machinists (IAM) v. OPEG, 477 F. Supp. 553, 569 (C.D. Cal. 1979) (citing 28 U.S.C. $\S \S ~ 1604,1605(a)(2)$ (1982)), affd, 649 F.2d 1354 (9th Cir. 1981), cert. denied, 454 U.S. 1163 (1982). For a more detailed discussion of the FSIA and its relationship to the act of state doctrine, see infra text accompanying notes 312-18.

15s The FSIA grants this jurisdiction by denying the sovereign immunity defense to foreign sovereigns when their actions involve commercial or private law activities. See 28 U.S.C. $\$ \S 1330,1605(a)(2)-(a)(3),(a)(5)$ (1982).

${ }^{154}$ See 477 F. Supp. at 567-68, discussed in OPEC, 649 F.2d at 1358.

165 Section 1603(d) of the FSIA, which defines commercial activity, specifically requires "reference to the nature of the course of conduct or particular transaction or act, rather than . . . reference to its purpose." 28 U.S.C. $\S 1603$ (d) (1982); see also H.R. REP. No. 1487, 94th Cong., 2d Sess. 16, reprinted in 1976 U.S. CODE CoNG. \& AD. NEws 6604,6615 (stating that under the FSIA the purpose of an activity is "irrelevant" in determining if its nature is commercial) [hereinafter cited as FSIA HousE REPORT]. 
court's error. ${ }^{158}$ Rather than reversing the district court's decision, however, it affirmed by relying on the act of state doctrine. ${ }^{157}$ In an opinion by Judge Choy, ${ }^{158}$ the appeals court initially held that the doctrine was not superseded by the FSIA. ${ }^{159}$ First quoting out of context a portion of the legislative history of the Act, ${ }^{\mathbf{1 6 0}}$ and then citing an outdated legislative report, ${ }^{161}$ the court incorrectly held that, despite passage of the FSIA, Congress desired to retain the act of state doctrine. ${ }^{162}$ Under the court's much-criticized ${ }^{163}$ two-step analysis, a finding that the FSIA confers subject-matter jurisdiction does not end the inquiry. The court must then determine, apart from the FSIA jurisdictional grant, whether

${ }^{158}$ See OPEC, 649 F.2d at 1358.

157 See id. at 1358-62.

${ }^{158}$ Curiously, five years earlier Judge Choy authored the Timberlane opinion, which took a much more flexible approach to the act of state doctrine. See supra text accompanying notes $138-46$.

169 See OPEC, 649 F.2d at 1359-60.

160 In order to establish support for its view that the FSIA was not meant to supersede the act of state doctrine, the OPEC court quoted part of a footnote from the 1976 FSIA HOUSE REPORT, supra note 155, that addressed the relationship between the FSIA and the act of state doctrine. See OPEC, 649 F.2d at 1359. The full sentence, with the portion omitted from $O P E C$ italicized, reads as follows: "The [joint HouseSenate] Committee has found it unnecessary to address the act of state doctrine in this legislation since decisions such as that in the Dunhill case demonstrate that our courts already have considerable guidance enabling them to reject improper assertions of the act of state doctrine." FSIA HOUSE REPORT, supra note 155, at 6619 n.1 (emphasis added). By failing to quote the entire sentence from the Report, OPEC falsely implied that the FSIA drafters wanted to retain an activist act of state doctrine. In fact, as the entire sentence shows, the FSIA drafters did not deal with the act of state doctrine because they felt that the majority in Dunhill had already severely limited it.

${ }_{101}$ The OPEC court improperly relied on a passage from a 1973 House Report stating that the FSIA "in no way affects existing law concerning the extent to which the 'act of state' doctrine may be applicable in similar circumstances." See 649 F.2d at 1359-60 (discussing Immunities of Foreign States: Hearings on H.R. 3493 Before the Subcomm. on Claims and Governmental Relations of the House Comm. ON THE Judiciary, 93d Cong., 1st Sess. 20 (1973)). This passage was rendered obsolete by the 1976 House Report, in which the

committee . . . emphasize[d] that [the] section-by-section analysis [of the 1976 legislation] supersedes the section-by-section analysis that accompanied the earlier version of the bill in the 93d Congress; the prior analysis should not be consulted in interpreting the current bill and its provisions, and no inferences should be drawn from differences between the two.

FSIA HOUSE REPORT, supra note 155, at 6611.

162 See OPEC, 649 F.2d at 1360.

103 See, e.g., Kestenbaum, Antitrust's "Extraterritorial" Jurisdiction: A Progress Report on the Balancing of Interests Test, 18 STAN. J. INT'L L. 311, 329 (1982); Comment, supra note 24, at 105-07; Comment, Antitrust Law-International Law-Act of State Doctrine-Foreign Antitrust Violations-International Association of Machinists \& Aerospace Workers v. Organization of Petroleum Exporting Countries (OPEC), 27 N.Y.L. ScH. L. REv. 1013, 1040 (1982); Comment, Act of State Doctrine: Applicability of United States Antitrust Law-International Association of Machinists \& Aerospace Workers v. Organization of Petroleum Exporting Ciountries, 23 Harv. INT'L L.J. 117, 122-23 (1982). 
the act of state doctrine would nonetheless bar the lawsuit. ${ }^{164}$ As a result, the court severely restricted the effectiveness of the FSIA. In effect, under the court's analysis, what the foreign sovereign cannot get through the "front door" of the FSIA, it obtains through the "back door" of the act of state doctrine. ${ }^{165}$ Courts both in the Ninth Circuit and other circuits have now begun to cite $O P E C$ 's expansive approach to the act of state doctrine as an easy means to avoid deciding difficult cases. ${ }^{168}$

Even if one accepts this "two hurdles" approach, the court's discussion in $O P E C$ fails to shed much light on the act of state doctrine. In applying the doctrine, the court did not explain its meaning or scope. ${ }^{167}$ Rather, after reciting the "classic formulation" of Underhill" 168 and paying homage to Sabbatino, ${ }^{169}$ the court went through a litany of factors that it said must be considered under the act of state doctrine and that in $O P E C$ precluded adjudication of the suit. First, the petro-politics questions in $O P E C$ raised the potential for interference with United States foreign policy. ${ }^{170}$ Second, the suit concerned issues in which both the executive and legislative branches were already "intimately involved."171 Third, there was an absence of international consensus on the suit's legal issues; price fixing, like expropriation, is not illegal

164 The drafters of the FSIA felt that the OPEC "two hurdles" approach would never be adopted by courts, since the Executive specifically argued in Dunhill against this "back door" use of the doctrine. See FSIA House REPORT, supra note 155, at 6619 n.1. Time, however, has proven the FSIA drafters wrong, as courts, despite the prohibitive language of Dunhill, continue to apply the doctrine widely and to use $O P E C$ 's "two hurdles" analysis.

The American Bar Association is now recommending the addition of a new section to the FSIA specifically removing the act of state defense when jurisdiction under the FSIA is present. This change would destroy the "two hurdles" approach of OPEC. For a discussion of the ABA proposal, see infra text accompanying notes 406-10.

${ }^{165}$ The phrase "back door" appears in the FSIA House Report, which warns against this very use of the act of state doctrine. The House Report finds it inappropriate for courts to deny jurisdiction through " the back door, under the guise of the act of state doctrine," when jurisdiction under the FSIA is available. FSIA HousE REPORT, supra note 155, at 6619 n.1 (quoting Amicus Brief of the United States at 41, Dunhill).

${ }^{188}$ See, e.g., Callejo v. Bancomer, S.A., 764 F.2d 1101, 1113 n.12 (5th Gir. 1985); MOL, Inc. v. People's Republic of Bangladesh, 572 F. Supp. 79, 83-84 (D. Or. 1983), affd, 736 F.2d 1326 (9th Cir.), cert. denied, 105 S. Ct. 513 (1984); Frolova v. Union of Soviet Socialist Republics, 558 F. Supp. 358, 363-364 (N.D. Ill. 1983), aff d, 761 F.2d 370 (7th Cir. 1985).

${ }^{167}$ Curiously, the $O P E C$ court itself impliedly criticized the doctrine by labeling it "amorphous." 649 F.2d at 1359. In the next breath, however, the court applied this "amorphous" doctrine to the case before it. See id. at 1359-62.

${ }^{188}$ See id. at 1358 (discussing language quoted supra text accompanying note 38).

169 See id. at 1359.

170 See id. at 1359-61.

171 See id. at 1361. 
under the laws of many countries. ${ }^{172}$ Fourth, the suit involved oil, a natural resource, which sovereign states have inherent power to preserve and protect for their own people. ${ }^{173}$ Finally, the commercial nature of the sovereigns' activities in the case did not automatically preclude application of the act of state doctrine. According to the OPEC court, while a commercial activity exception limits the doctrine of sovereign immunity, there is no such exception to the act of state doctrine; when the courts must avoid an affront to state sovereignty, "the act of state doctrine remains available... regardless of any commercial component of the activity involved." 174 How these factors work together to create a cohesive doctrine was not explained by the court. Because the court failed to provide guidance on the meaning and scope of the doctrine, later courts were left to ponder what, if any, rule of law may be discerned from the $O P E C$ opinion.

Moreover, the court's reasons for invoking the act of state doctrine are unpersuasive. The potential for interference with the Executive's conduct of United States foreign affairs is not a valid ground, in and of itself, for avoiding a decision on the merits. First, the FSIA dictates that American courts may not rely on sovereign immunity doctrine to dismiss United States-related disputes involving international commerce, even if such disputes have the potential, as many times they do, for affecting United States foreign policy. ${ }^{175}$ Second, courts have not shied away from deciding other questions that have major foreign policy implications. A good example is international extradition. Under American law, the courts decide whether the United States should honor extradition requests from foreign governments. Each time a court rules on the validity of an extradition request by a foreign sovereign, it steps into the sensitive arena of foreign relations, with the potential for embarrassing the Executive; yet courts decide these cases freely and without deference to the Executive. ${ }^{176}$ Finally, virtually every international

${ }^{172}$ See id.

174 Id. at 1360 . A subsequent Ninth Gircuit court was reluctant to adopt the OPEC position on this point. See Clayco Petroleum Corp. v. Occidental Petroleum Corp., 712 F.2d 404, 408 (9th Cir. 1983) (asserting that the "Ninth Circuit has not definitely ruled on the commercial exception"), cert. denied, 464 U.S. 1040 (1984).

178 See 28 U.S.C. $\S 1605$ (a)(2)-(a)(3) (1982); FSIA HouSE REPORT, supra note 155 , at 6605-06, 6617-18. Moreover, even under a broad interpretation of the act of state doctrine, courts will adjudicate disputes involving property located in the United States regardless of potential embarrassment to the Executive or interference with United States foreign policy. See infra notes 297-300 and accompanying text.

178 For a more detailed discussion of the law of extradition, see supra note 61 . 
dispute may involve a foreign sovereign in some respect. ${ }^{177}$ Taken to its logical conclusion, the OPEC decision, like the Second Gircuit's Hunt decision, would close American courts to all international disputes in the interest of avoiding embarrassment to our foreign policy.

The court's other rationales-that it should not judge OPEC's acts because they involve regulation of a national resource and because there is no international consensus on this issue-are likewise unpersuasive. The OPEC nations' international sales of oil and fixing of prices, unlike the foreign acts of expropriation in Sabbatino, are purely commercial in nature. If the OPEG nations wish to enter world commerce, and act not like nations but like private traders, then they should be treated as such. ${ }^{178}$ International law, with its adherence to the "restrictive" theory of sovereign immunity ${ }^{179}$ and the distinction between "public law" (nations acting in their sovereign capacity) and "private law" (nations acting in their private, commercial capacity), ${ }^{180}$ would seem to support such treatment. ${ }^{181}$

177 Cf. Castro v. Saudi Arabia, 510 F. Supp. 309, 312 (W.D. Tex. 1980):

The transaction at issue here could be broadly defined as the "sale of services" and so be deemed "commercial." But the activity could also be narrowly viewed as a non-profit agreement between two governments for the training of military personnel. So viewed, the transaction would be public or governmental, and protected by sovereign immunity.

${ }^{178}$ See Dunhill, 425 U.S. at 703-04 (White, J., concurring):

Participation by foreign sovereigns in the international commercial market has increased substantially in recent years. . . . The potential injury to private businessmen - and ultimately to international trade itself-from a system in which some of the participants in the international market are not subject to the rule of law has therefore increased correspondingly. . . . In their commercial capacities, foreign governments do not exercise powers peculiar to sovereigns. Instead, they exercise only those powers that can also be exercised by private citizens. Subjecting them . . . to the same rules of law that apply to private citizens is unlikely to touch very sharply on "national nerves."

179 See FSIA House Report, supra note 155, at 6605; J. Sweeney, C. Oliver \& N. LEECH, supra note 61, at 301-11.

180 FSIA House RePort, supra note 155, at 6605; J. SweENEy, C. Oliver \& N. LEECH, supra note 61, at 311-24.

181 How, then, should the $O P E C$ case have been decided? Rather than relying on a variety of disoriented pronouncements gleaned from other cases applying the act of state doctrine, and in the process severely interfering with the effectiveness of the FSIA, the court could have decided the case by actually examining the antitrust claims that the union brought against OPEC. In so doing, the court would have found that the plaintiffs' antitrust action was improper. As the district court had already found, see $477 \mathrm{~F}$. Supp. at 561, the union could not obtain monetary damages against OPEC and its member nations because of the indirect-purchaser rule of Illinois Brick Co. v. Illinois, 431 U.S. 720 (1977). Plaintiffs were left, therefore, only with the possibility of obtaining injunctive relief. However, even a cursory examination of the OPEC nations' allegedly wrongful acts indicates that injunctive relief could not be obtained under the Sherman and Clayton Acts. First, OPEC is not a "person" within the meaning of the 
The Ninth Circuit's confusion about the act of state doctrine in the aftermath of OPEC is illustrated by Clayco Petroleum Corp. v. Occidental Petroleum Corp. ${ }^{182}$ Clayco involved a suit between two American oil companies, one (Clayco) accusing the other (Occidental) of obtaining a valuable offshore oil concession from the sovereign Arab sultanate of Umm Al Qaywayn by paying bribes to the sultan. Clayco claimed that Occidental's payment violated the Foreign Corrupt Practices Act of 1977 (FCPA). ${ }^{183}$

Defendant Occidental maintained that the act of state doctrine prevented adjudication of Clayco's allegations. The defendant relied in part on the disposition of an earlier case involving a similar dispute: Occidental Petroleum Corp. v. Buttes Gas $\&$ Oil Co. ${ }^{184}$ In that action, Occidental accused Clayco and Buttes of bribing a neighboring sultan to obtain his aid in the contest for the oil concession. According to Occidental, Clayco and Buttes sought to induce the sultan to assert a territorial claim that would have prevented Occidental from obtaining oil rights in the area. The Buttes court never reached the merits of Occidental's claim; invoking the act of state doctrine, it dismissed the case. ${ }^{185}$

The Ninth Circuit reached the same result in Clayco, but in doing so it did not appear to be following any well-defined rule of law. Because of the vague nature of the doctrine and the conflicting signals given by the Supreme Court and by the Ninth Gircuit itself in

Sherman Act. See $3 \mathrm{~J}$. von Kalinovski, ANTitrust Laws and Trade RegulaTIONS $\S 7.02[1]$, at 7-29 (1984) (An association, though not defined under the Sherman Act, "is generally defined by common law to be an organization of persons."). Second, the allegedly wrongful conduct does not come within the extraterritorial coverage of the antitrust laws. See Timberlane Lumber Co. v. Bank of Am. Nat'l Trust \& Sav. Ass'n, 749 F.2d 1378, 1382-86 (9th Cir. 1984); Leigh, Act of State Doctrine-Foreign Sovereign Immunities Act-Judicial Restraint in Foreign Policy Arena, 76 AM. J. INT'L L. 160, 162 (1982). Without resort to the Sherman and Clayton Acts, the plaintiffs have no remedy, since cartels are not prohibited under international law. See Act of State Hearings, supra note 10, at 30. Thus, the OPEC nations' activities are probably legal under both American and international law.

The OPEC court, therefore, could have easily disposed of the case on its merits. Such a disposition, contrary to the court's view, would not have had a different effect on congressional or executive efforts to condemn the OPEC nations' policies than a disposition of the case on act of state grounds. Either way, the action fails, and the OPEC nations probably would not appreciate the difference. The effect on foreign relations would thus be minimal.

182712 F.2d 404 (9th Gir. 1983), cert. denied, 464 U.S. 1040 (1984). The case is summarized in 78 AM. J. INT'L L. 446-49 (1984).

18315 U.S.C. $\S \S 78 \mathrm{~m}(\mathrm{~b}),(\mathrm{d})(1)$, (g)-(h), $78 \mathrm{dd}-1$ to $-2,78 \mathrm{ff}(\mathrm{a}),(\mathrm{c})(1982)$. For a further discussion of the FCPA, see infra text accompanying notes 330-35.

284331 F. Supp. 92 (C.D. Cal. 1971), affd, 461 F.2d 1261 (9th Gir.) (per curiam), cert. denied, 409 U.S. 950 (1972).

${ }^{185}$ See id. at 113. 
Timberlane and OPEC, the court could do little more than to compare the facts before it with those of other act of state cases. The court found that the sovereign involvement here was more substantial than in Timberlane but comparable to that in Buttes. ${ }^{186}$ Moreover, the court asserted that in order to decide the case it had to examine the motivation of the foreign sovereign in taking the bribe, which it was unwilling to do. ${ }^{187}$ The court also recognized that decisions within the Ninth Circuit are in conflict on the recognition of the "commercial activity" exception to act of state doctrine. ${ }^{188}$ The court suggested, however-citing the four-member plurality opinion in Dunhill ${ }^{189}$ _that even if such an exception does exist, it is limited to situations in which governments are not exercising powers unique to sovereigns. ${ }^{190}$ According to the court, the governmental action in Clayco (granting oil concessions), unlike the action in Dunhill (debt repudiation accompanying the nationalization of foreign assets), could not have been taken by a private citizen and therefore came within the purview of the act of state doctrine. ${ }^{191}$ Of course, the court was mistaken; clearly the activity in Dunhill also could not have been taken by a private citizen.

Finally, the court was willing to abrogate the private enforcement mechanisms of the FCPA. Although the court recognized that the FCPA permits actions by private parties, ${ }^{182}$ it held that these actions are not available when a foreign government is involved. ${ }^{193}$ Since any FCPA action inevitably involves payment by a private party to an official of a foreign government, foreign sovereigns will always be involved in private lawsuits brought for violation of the FCPA. Under the Clayco reasoning, therefore, a private lawsuit for violation of the FCPA is apparently barred.

\section{The Third Gircuit}

One of the most frequently cited opinions on the act of state doctrine outside of the Second and Ninth Circuits is Mannington Mills, Inc. v. Congoleum Corp., ${ }^{194}$ decided by the Third Circuit in 1979.

${ }^{186}$ See Clayco, 712 F.2d at 406-07.

187 See id.

188 See id.

189 See id. at 408 (citing Dunhill, 425 U.S. at 704).

190 See id. In effect, the Clayco court adopted the strict view of the Second Circuit's Hunt case, applying the act of state doctrine to avoid examining the motivations of a foreign sovereign.

191 See id.

192 See id. at 409.

193 Id.

194595 F.2d 1287 (3d Cir. 1979). 
Mannington Mills, an American manufacturer of floor material, alleged that Congoleum, a competitor, had fraudulently obtained foreign patents and, in violation of antitrust laws, was threatening to use these patents against it in infringement actions abroad. ${ }^{195}$ In its defense, Congoleum claimed that Mannington's antitrust action was barred by the act of state doctrine. ${ }^{196}$ The district court agreed with Congoleum and dismissed the case. ${ }^{197}$

The Third Circuit reversed. Following the flexible approach of the Ninth Circuit in Timberlane, ${ }^{198}$ the court refused to apply the act of state doctrine, despite the fact that adjudication would force the court to judge both the validity of the foreign act and the foreign government's motivation. ${ }^{199}$ The court also acknowledged that "enforcement of a decree might possibly present problems of international relations." 200 Nevertheless, the court was willing to examine such governmental activities because it did not accept the defendant's "proposition that the mere issuance of patents by a foreign power constitutes ... an act of state, as that term has developed under case law." ${ }^{201}$ According to the court, "The grant of a patent is quite different from an act of expropriation by a government."202

Mannington Mills, although praised by one commentator for its "flexible approach" to the act of state doctrine, ${ }^{203}$ unfortunately did not set out clear standards for future application of the doctrine. For example, the court did not elucidate the distinction, for purposes of the doctrine, between a government's act of expropriation and a government's issuance of a patent. Both, of course, involve purely sovereign activity. Moreover, if the defendant obtained the foreign patent through fraud, then its conduct is similar to the activity of the defendant in Clayco, ${ }^{204}$ in which the defendant acted improperly to obtain an oil concession. It is difficult to understand why the act of state doctrine permits examination of one activity while precluding examination of the other.

195 Id. at 1290.

196 Id.

197 The district court reasoned that "the validity of the foreign patents was to be determined by the courts of the respective issuing nations." Id.

198 See supra notes 138-46 and accompanying text.

190 See Mannington Mills, 595 F.2d at 1290.

200 Id. at 1294.

201 Id. at 1293-94.

202 Id. at 1294.

203 See Comment, supra note 3, at 560.

${ }^{204}$ See supra text accompanying notes 182-93. 


\section{The District of Columbia Circuit}

In 1984, the District of Columbia Circuit, sitting en banc, issued its opinion in Ramirez de Arellano v. Weinberger. ${ }^{205}$ An American Bar Association report has called the opinion's act of state discussion "excellent" and "monumental."208 Because the opinion contains a wide-ranging discussion of the doctrine and was issued en banc, it may be widely discussed, and perhaps frequently cited, in the future.

The plaintiff in Ramirez was an American citizen who owned a 14,000-acre cattle ranch in Honduras. Unbeknownst to him, the United States government, with the permission of Honduras, picked his land as the site for the training of Salvadoran soldiers. According to the plaintiff, the American military constructed a military center housing more than 1,000 soldiers and began conducting training exercises using live ammunition. ${ }^{207}$

Unable to convince the American military to leave, the plaintiff brought suit in district court against the Secretaries of State and Defense, seeking to enjoin them from trespassing on his property. He alleged that the military facility was built on his ranch without constitutional or statutory authority and that the occupation had deprived him of the use and enjoyment of his property without due process of law.

The district court granted the government's motion to dismiss the suit on the grounds that it presented a nonjusticiable political question involving United States foreign policy in Central America. ${ }^{208} \mathrm{~A}$ panel of the District of Columbia Circuit, in a two-to-one decision, affirmed. ${ }^{208}$

In a six-to-four decision, the full circuit reversed the panel. ${ }^{210}$ The court, in a lengthy opinion by Judge Wilkey, first rejected the district court's reliance upon the political question doctrine to dismiss the case. $^{211}$ While the court acknowledged that the plaintiff's suit raised

${ }^{205} 745$ F.2d 1500 (D.C. Cir. 1984) (en banc), vacated mem., 105 S. Ct. 2353 (1985).

${ }^{208}$ ABA Ad Hoc Committee on the ALI Restatement of the Foreign Relations Law of the United States, Comments on Sections 428 and 429 of the Draft Restatement (The Act-of-State Doctrine) 4 (1984).

207 See Ramirez, 745 F.2d at 1507.

208 See Ramirez de Arellano v. Weinberger, 568 F. Supp. 1236, 1238-40 (D.D.C. 1983), rev'd en banc, 745 F.2d 1500 (D.C. Cir. 1984), vacated mem., 105 S. C.. 2353 (1985).

${ }^{200}$ See Ramirez de Arellano v. Weinberger, 724 F.2d 143 (D.C. Cir. 1983), rev'd en banc, 745 F.2d 1500 (D.C. Cir. 1984), vacated mem., 105 S. Ct. 2353 (1985).

${ }^{210}$ For a contemporary report on the case, see Honduran Cattle Rancher Wins Round Against U.S., Nat'l L.J., Oct. 22, 1984, at 9, col. 1.

211 See Ramirez, 745 F.2d at 1511-15. The original Ramirez panel reached the same conclusion. See 724 F.2d at 147. 
some foreign policy considerations, it characterized the task before it as a purely judicial function: determining whether the taking of property of an American citizen by the federal government was constitutionally proper. ${ }^{212}$ The fact that the property was located in Honduras was inconsequential.

Next, the court disagreed with the panel's suggestion that injunctive relief would impair the Executive's conduct of foreign affairs in Central America. The full court felt that carefully tailored equitable relief could avoid this problem. ${ }^{213}$

In the last section of the opinion, the court held that the defendant was not entitled to a dismissal on act of state grounds and remanded the case to the district court. Noting that "[s]eparation of powers concerns are the underpinnings of the act of state doctrine,"214 it held that a successful act of state defense requires two showings: first, that an act of state has occurred, and second, that the case does not fall within any legally recognized exception to the doctrine. ${ }^{215}$

The court found, on the record before it, that neither showing had been made. According to the court, the defendant proved that Honduras had taken steps toward expropriating the rancher's property. But because the expropriation was not complete, the court did not view it as an act of state sufficient to compel dismissal of the case. ${ }^{\mathbf{2 1 6}}$ The court further stated, in dicta, that the United States would probably be unable to refute the assertion of exceptions to the doctrine. ${ }^{217}$ For instance, an existing treaty between the United States and Honduras guaranteeing payment for any expropriations of American-owned property could bring this case within the "treaty exception" enunciated in Sabbatino. ${ }^{218}$

However, because the act of state defense had not been raised

212 See 745 F.2d at $1515-20$.

213 See id. at 1521-33.

214 Id. at 1534.

216 See id. at 1534-43. Ramirez is the first case to employ this two-step analysis as a means of deciding act of state cases.

${ }^{216}$ See id. at 1536.

217. See id. at 1539-42.

218 For a discussion of the treaty exception, see infra text accompanying notes 283-92. The court brought up two other possible bars to application of the doctrine-the first and second Hickenlooper amendments. See infra notes 393-98 and accompanying text. Neither, however, would have been effective as a bar. As Judge Starr's dissent correctly pointed out, see 745 F.2d at 1572-74, the first Hickenlooper amendment does not require a cutoff of aid to an American ally such as Honduras, and even if it did, that would have no effect on the act of state analysis. The second Hickenlooper amendment, contrary to the court's suggestion, has been uniformly interpreted to apply only to expropriated property that is transported into the United States. See, e.g., cases cited infra note 398. This, of course, did not occur in Ramirez. 
before the district court, the majority felt that it would be inappropriate for the court of appeals to determine whether the doctrine was applicable. It therefore remanded the case to the district court. ${ }^{219}$

The Ramirez dispute may finally be resolved through the political process. Following the full Circuit's opinion, the United States apparently decided to close the military center because Honduras was preventing it from training Salvadoran soldiers there. ${ }^{220}$ Subsequently, the Supreme Court, in a one paragraph order, vacated the court of appeals' opinion and remanded the case for reconsideration "in light of the Foreign Assistance and Related Programs Appropriations Act . . . and other events occurring since October 5, 1984 [the date of the $R a$ mirez decision]."221

Despite these developments, the Ramirez opinion remains important. Its detailed and comprehensive argument for a strict construction of the act of state doctrine provides an essential counterweight to the broad applications of the doctrine by the Second and Ninth Gircuits in Hunt and OPEC, respectively. In contrast to these decisions, Ramirez clearly provides that the act of state doctrine should not be invoked cavalierly whenever some foreign governmental involvement looms in the background. More importantly, under the Ramirez analysis plaintiffs do not have to prove lack of sovereign involvement in international transaction cases to have their claims adjudicated. Rather, the court placed the burden of proving the applicability of the act of state doctrine on the defendant, requiring the twofold showing described above. To date, no other court has imposed such prerequisites for application of the doctrine.

General acceptance of the Ramirez analysis could lead to a much more limited use of the act of state doctrine. ${ }^{222}$ However, the Ramirez decision itself shows the disagreement of the District of Columbia Circuit on the issue, ${ }^{223}$ and perfectly illustrates the discord that currently exists both among and within the circuits on the act of state doctrine.

219 See Ramirez, 745 F.2d at 1545.

220 See U.S. Will Shut Honduras Base, L.A. Times, Mar. 18, 1985, at 1, col. 3.

221 Weinberger v. Ramirez de Arellano, 105 S. Ct. 2353, 2354 (1985) (mem.).

${ }^{222}$ For the most part, the federal district courts have been relying on much broader formulations of the act of state doctrine. One commentator characterizes the district courts' treatment of the doctrine as 'barring [courtroom] doors at the slightest suggestion of involvement of a foreign government in a case." Mathias, supra note 2, at 405; see also Sharon v. Time, Inc., 599 F. Supp. 538, 553 (S.D.N.Y. 1984) ("The substantial and rapid accumulation of authority in favor of a broadened use of the lact of state] doctrine as a vehicle for judicial abstention has all taken place in the lower federal courts .....").

223 Judge Starr's dissent sharply criticized the majority for "an unsupportably narrow view of the substance and purpose of [the act of state] doctrine." Ramirez, 745 F.2d at 1566 (Starr, J., dissenting). 


\section{Executive Pronouncements on the Act of State Doctrine: Inconsistent Recommendations}

While courts disagree about the exact scope and meaning of the act of state doctrine, they do agree on one point: the doctrine is based substantially, if not totally, on deference to the Executive in its conduct of foreign policy. For this reason, many of the lower courts, ${ }^{224}$ and some Justices of the Supreme Court, ${ }^{225}$ have been extremely sensitive to executive pronouncements on the act of state doctrine. The Executive, recognizing the important role it can play in influencing a court's decision whether to dismiss on act of state grounds, has not shied away from making its position known. Unfortunately, the Executive has taken inconsistent positions on the applicability of the doctrine, thereby sending out confusing and contradictory signals.

In 1963, while Sabbatino was before the Second Circuit, ${ }^{226}$ the executive branch made its first major pronouncement on the act of state doctrine. In that year, the State Department issued two letters on the subject, including one that strongly intimated that the doctrine should not be applied in Sabbatino. ${ }^{227}$ The Second Circuit affirmed the district court's rejection of the doctrine, primarily in reliance on those letters. ${ }^{228}$

However, a year later, when Sabbatino came before the Supreme Court, the Executive reversed its position, urging in a brief filed by the Solicitor General the retention of a strong and wide-ranging act of state doctrine. ${ }^{22 \theta}$ While Justice Harlan's opinion in Sabbatino never ex-

${ }^{224}$ See, e.g., Kalamazoo Spice Extraction Co. v. Provisional Military Gov't of Socialist Ethiopia, 729 F.2d 422, 424 (6th Cir. 1984); Banco Nacional de Cuba v. Sabbatino, 307 F.2d 845, 857-58 (2d Cir. 1962), rev'd, 376 U.S. 398 (1964).

${ }^{228}$ In Citibank, for example, three Justices explicitly adopted the Bernstein exception. See 406 U.S. at 768.

${ }^{228}$ See supra notes $71-72$ and accompanying text.

${ }^{227}$ The text of the letters is reproduced in the Sabbatino circuit court opinion. See 307 F.2d at 858.

${ }^{228}$ See id. at 858-59.

229 See Brief for the United States as Amicus Curiae, Sabbatino, reprinted in 2 Int'l Legal Materials 1009 (1963). Professor Richard Falk at the time commented on the Executive's position as follows: .

As the amicus brief of the United States government now makes evident, the lower federal judges, who had explained the suspension of normal deference under the act of state doctrine as something that could (and perhaps should) be done to carry out the wishes of the executive, were in error. The executive did not want the act of state doctrine suspended. This discloses that the faulty notion of judicial subservience was also mistaken in fact, since the wrong message was received. The courts were not entitled and were certainly not requested, according to the executive, to examine the validity of these Cuban acts of state.

R. FALK, supra note 4 , at 117.

The Second Circuit recently committed this same error-incorrectly anticipating 
pressly acknowledged that the Court was following the recommendation of the Executive, ${ }^{230}$ its formulation of the act of state doctrine mirrored the position expressed in the Solicitor General's brief. ${ }^{\mathbf{2 3 1}}$

By the time the Citibank case was decided, in 1972, the Executive was taking a less expansive position on the doctrine. In a letter submitted while Citibank was before the Supreme Court, ${ }^{232}$ the State Department urged that the doctrine not be applied whenever either (1) the Executive so advises the judiciary-arguing, in effect, that the Court should adopt the Bernstein exception ${ }^{233}$ or (2) the private litigant's claim seeks only a setoff against a foreign sovereign's claim, and certain other conditions are met. ${ }^{234}$ The Citibank letter referred to the rise in the 1960's of expropriations of American assets by foreign governments. ${ }^{235}$ These "[r]ecent events," the letter strongly implied, called for a less expansive application of the act of state doctrine than that set out in Sabbatino. ${ }^{238}$

In 1976 , by the time of the Dunhill decision, the Executive had made a complete turnabout from its position in Sabbatino. In a letter that the State Department filed in Dunhill, ${ }^{237}$ the Executive urged that (1) the doctrine not be applied in that case; ${ }^{238}(2)$ the Bernstein and

the Executive's position on the act of state doctrine-in Allied Bank Int'l v. Banco Credito Agricola de Cartago, 757 F.2d 516 (2d Cir. 1985). In Allied Bank, the district court applied the act of state doctrine to deny the plaintiff's motion for summary judgment in a suit against Costa Rican banks. See Allied Bank Int'l v. Banco Credito Agricola de Cartago, 566 F. Supp. 1440, 1444 (S.D.N.Y. 1983), rev'd, 757 F.2d 516 (2d Cir. 1985). The court reasoned that failure to apply the act of state doctrine might subject the Executive to embarrassment in its dealings with Costa Rica. See id. The Second Circuit initially affirmed but, on rehearing, vacated its original order and reversed the district court. The court explained that its turnabout was in response to the filing of an amicus brief by the Justice Department. The brief stated, contrary to the court's initial supposition, that the Executive viewed the banks' repudiation of their debts as contrary to United States policy. See Allied Bank, 757 F.2d at 519.

230 See Sabbatino, 376 U.S. at 420 .

${ }^{231}$ Compare Sabbatino, 376 U.S. at 430-32 with Brief for the United States as Amicus Curiae, Sabbatino, supra note 229, at 1018. See also Stevenson, The State Department and Sabbatino-_Ev'n Victors Are By Victories Undone," 58 AM. J. INT'L L. 707, 707-08 (1964) (Sabbatino adopted the State Department's position "with a vengeance.").

232 For the full text of the State Department letter, see Banco Nacional de Cuba v. First Nat'l City Bank, 442 F.2d 530, 536-38 (2d Cir. 1971), rev'd, 406 U.S. 759 (1972).

233 Id. at 537.

${ }^{234}$ See id. The State Department reaffirmed this position in 1973 and 1980 Bernstein letters. See Banco Nacional de Cuba v. Chase Manhattan Bank, 658 F.2d 875, 884 (2d Cir. 1981).

235 See 442 F.2d at 537.

288 See id.

${ }^{237}$ See Dunhill, 425 U.S. at 706-11 (appendix 1 to the opinion of Justice White).

${ }^{238}$ See id. at 707, 710 . 
commercial activity exceptions be recognized, ${ }^{239}$ and (3) Sabbatino be overruled. ${ }^{240}$ Indeed, the Executive strongly intimated that the doctrine should be abolished altogether. ${ }^{241}$

The Executive's last major input into the act of state doctrine occurred in a 1982 Sixth Gircuit case, Kalamazoo Spice Extraction Co. v. Provisional Military Government of Socialist Ethiopia. ${ }^{242}$ In the socalled "Robinson letter" (named after its author, State Department Legal Adviser Davis Robinson), ${ }^{243}$ which was submitted to the Kalamazoo court, the Executive no longer mentioned disagreement with Sabbatino or urged abolition of the doctrine. ${ }^{244}$ The letter requested that the judiciary follow the Executive's views on when the doctrine should be applied, ${ }^{245}$ but added that in a case in which there exists an applicable legal standard, such as that provided by a treaty, the Executive would make its wishes known only if it felt that foreign policy concerns required judicial abstention. ${ }^{246}$ The Robinson letter revealed the Executive's bias against the act of state doctrine by stressing that a "broad, inflexible rule of abstention in expropriation cases is not necessary to safeguard our foreign policy interests."247

An examination of the Executive's changing views on the act of state doctrine, from Sabbatino in 1964 to Kalamazoo Spice in 1982, illustrates a number of important points. First, the Executive, like the courts, has not expressed a clear and consistent view of the act of state doctrine. Second, and more importantly, the Executive, unlike the courts, is a political branch of the government, and therefore its pro-

239 See $i d$. at 707.

240 See id. at 710.

241 See id. at 709-10. The entire tone of the letter leads one to conclude that the State Department wished the doctrine abolished. The State Department even pointed out that other nations, including Great Britain, do not recognize the act of state doctrine with respect to violations of international law and yet do not suffer serious judicial interference with their foreign policy. See id. at 710.

242729 F.2d 422 (6th Cir. 1984).

243 Letter from Davis R. Robinson to Solicitor General Rex E. Lee (Nov. 19, 1982), reprinted in 22 INT'L LEGal Materials 207 (1983) [hereinafter cited as Robinson letter]. The Sixth Circuit in Kalamazoo Spice-apparently influenced by the Executive's amicus brief, which incorporated the gist of the Robinson letter-reversed the district court's act of state dismissal on the grounds urged in the brief. Kalamazoo Spice also illustrates how the Bernstein approach may lead to the unequal treatment of litigants. Without the Executive's intervention in the case, it seems probable that the Sixth Gircuit would have merely affirmed the district court's opinion.

244 See Robinson letter, supra note 243.

246 "If we indicate that adjudication would be inconsistent with foreign policy interests of the United States, we trust that the court will give appropriate weight to our views." Id. at 208. This statement, of course, indirectly urges courts to adopt the Bernstein exception to the act of state doctrine.

246 See id.

247 See id. 
nouncements on the doctrine have been based on political expediency. When the Executive found that the doctrine would serve its purposes, as it did during the Sabbatino litigation, it promoted the doctrine. Later, when it found a court's use of the doctrine not to its liking, it urged its outright abolition or major curtailment. The only consistency in its positions, from Sabbatino to the present, is that in each case it has urged courts to adopt a policy of automatically following its recommendations.

As a result of its inconsistent pronouncements, the Executive has been a major culprit in creating judicial confusion about the act of state doctrine. Without the Executive's involvement, the judiciary might by now have formulated a workable and consistent doctrine for international transaction cases. ${ }^{248}$

\section{Sowing the Seeds of Confusion: Problems Created by The ACT of State Doctrine}

As the above discussion reveals, there is a great deal of confusion about the act of state doctrine in practice. The courts have been unable to determine its scope or to construct a consistent scheme for its application. ${ }^{249}$ This confusion has produced cases with unfair results, attenuated the reach of important federal legislation, and stymied the development of international law. This section will discuss in more detail the numerous problems created by the application, or more correctly, the misapplication, of the act of state doctrine.

\section{A. Fostering Widespread Confusion}

\section{Disagreement About the Meaning and Scope of the Doctrine}

Part of the confusion about the act of state doctrine may stem from the simple fact that the term "act of state" is a misnomer: virtually any governmental action can be characterized as an act of state. Almost every international transaction today has some link to a foreign govern-

${ }^{248}$ The related doctrine of sovereign immunity also was hopelessly confused during the period when the Executive offered the courts its suggestions on when to apply it. Under that regime, as with the act of state doctrine today, politics, and not the rule of law, dictated whether sovereign immunity would be applied. In response, Congress in 1976 passed the FSIA, whose major purpose was to abolish the old Executive-dictated approach to sovereign immunity and replace it with a doctrine to be shaped solely by the courts, without Executive interference. For background on the FSIA and its effect on the doctrines of sovereign immunity and act of state, see infra notes 312-18 and accompanying text.

249 For an example of a foreign scholar's frustration in trying to understand the act of state doctrine, see Jones, supra note 21 , at 466. 
ment, ${ }^{250}$ and therefore every such transaction that generates a dispute can lead to application of the doctrine.

Of course, the courts have recognized the impropriety of such a result and have attempted to limit their use of the doctrine to situations in which the foreign sovereign's involvement is significant. ${ }^{261}$ The problem, however, is that courts have been unable to agree on how much involvement is necessary to trigger the doctrine's application. In Dunhill, for instance, a majority of the Supreme Court felt that without an official decree repudiating the interventors' obligations there was not enough sovereign involvement to warrant dismissal. ${ }^{262}$ In Ramirez de Arellano v. Weinberger, ${ }^{253}$ the District of Columbia Circuit held that, even if the president of a foreign country has officially decreed an expropriation, no "act of state" has occurred until the expropriation has been completed. ${ }^{254}$ Yet in cases in which the foreign government's involvement was much less direct than in Dunhill and Ramirez-such as Hunt v. Mobil Oil Corp. ${ }^{255}$ and Clayco Petroleum Corp. v. Occidental Petroleum Corp. ${ }^{258}$ which involved only the background presence of foreign governments-the act of state doctrine has been applied.

Faced with the difficulty of trying to determine the extent of foreign governmental activity necessary to constitute an "act of state," most courts have focused primarily on whether adjudicating the controversy might interfere with the foreign policy of the United States. ${ }^{287}$ The Ninth Circuit's decision in International Association of Machin-

${ }^{250}$ In most nations of the world, including some western democracies, the government owns either all or a large part of the nation's economic enterprises. In addition, most governments are intimately involved with their country's foreign trade. As a result, almost all international disputes involve a foreign government to some degree. See generally D. Lamont, Foreign State Enterprises (1979); R. MONSEN \& K. Walters, Nationalized Companies: A Threat to American Business (1983); State-OWNed ENTERPRISE IN THE WeStern Economies (R. Vernon \& Y. Aharoni eds. 1981); The State in the Market, Economist, Dec. 30, 1978, at 37.

251 See, e.g., Dunhill, 425 U.S. at 694-95; Ramirez de Arellano v. Weinberger, 745 F.2d 1500, $1537-38$ (D.C. Gir. 1984) (en banc), vacated mem., 105 S. Ct. 2353 (1985); Mannington Mills, Inc. v. Congoleum Corp., 595 F.2d 1287, 1293-94 (3d Cir. 1979); Timberlane Lumber Co. v. Bank of Am. Nat'l Trust \& Sav. Ass'n, 549 F.2d 597, 608-09 (9th Cir. 1976).

252 See Dunhill, 425 U.S. at 694-95.

${ }^{253} 745$ F.2d 1500 (D.C. Gir. 1984) (en banc), vacated mem., 105 S. Ct. 2353 (1985).

254 Id. at $1534-36$

${ }^{255} 550$ F.2d 68, 72-75 (2d Cir. 1977); see also supra notes 119-23 and accompanying text.

${ }_{258} 712$ F.2d 404, 407-08 (9th Cir. 1983), cert. denied, 464 U.S. 1040 (1984); see also supra notes $182-93$ and accompanying text.

257 See, e.g., supra text accompanying notes $139-40,170$ \& 200; infra text accompanying note 306 . 
ists (IAM) v. OPEC $C^{258}$ articulated this rationale when it refused to decide whether OPEC's price-fixing activities should be declared illegal. ${ }^{258}$ In other cases, this rationale has been used either alone or in conjunction with the "extent of sovereign activity" rationale in determining whether to apply the act of state doctrine. ${ }^{280}$

The problem with this criterion, however, is that virtually every court decision involving an international transaction has the potential of interfering with the foreign policy interests of the United States. When a foreign government is directly involved as a party and a suit is decided against it, there is obviously the potential for embarrassment to the executive branch. On the other hand, if the court's judgment is in favor of the foreign sovereign, the result may be contrary to the goals of the Executive. Indeed, United States foreign policy may be affected even when the foreign sovereign is involved only indirectly in the transaction: our foreign policy is wide-ranging and involves not only national defense but also international commerce. ${ }^{261}$

Similar problems arise when courts try to determine the application of the act of state doctrine on the basis of another factor: the purpose of the foreign sovereign's activity. Clayco and $O P E C$, for example, state that if the sovereign's activity can be considered to have a public purpose, courts should apply the act of state doctrine to avoid judging that activity. ${ }^{262}$ Contracts for the sale of commercial goods ranging from oil and gas $^{263}$ to rhesus monkeys ${ }^{264}$ have been characterized as public acts, leading to the application of the act of state doctrine; in the courts' view, these commercial transactions involve a sovereign's purpose to preserve its scarce natural resources. This rationale, however, like the one focusing on interference with foreign policy, covers far too many situations: virtually every activity of a foreign sovereign has a public purpose. Thus, seemingly commercial activities, such as those mentioned above, can be characterized as noncommercial and public by

${ }^{258} 649$ F.2d 1354 (9th Gir. 1981), cert. denied, 454 U.S. 1163 (1982).

${ }^{259}$ See id. at 1359-60.

280 See, e.g., Timberlane Lumber Co. v. Bank of Am. Nat'l Trust \& Sav. Ass'n, 549 F.2d 597, 605-06 (9th Cir. 1976).

${ }_{281}$ Various federal laws, regulations, and controls deal with international commerce. To enforce these laws, the United States not only has the Department of Commerce, but also the United States Trade Representative, a member of the Cabinet specifically charged with directing foreign policy on international trade. See generally J. Jackson, International Economic Relations, Cases and Materials 75-279, 433-941 (1977); A. Lowenfeld, Public Controls on International Trade (1979); A. Lowenfeld, Trade Controls for Political Ends (1977).

${ }_{262}$ See Clayco, 712 F.2d at 406; OPEC, 649 F.2d at 1360.

${ }^{263}$ See id. at 405; OPEC, 649 F.2d at 1355; Hunt, 550 F.2d at 70-72.

264 See MOL, Inc. v. Peoples Republic of Bangladesh, 572 F. Supp. 79, 81 (D. Or. 1983), affd, 736 F.2d 1326 (9th Cir.), cert. denied, 105 S. Ct. 513 (1984). 
looking to the activity's underlying purpose. It is noteworthy that courts struggled for over forty years with this "underlying purpose of the commercial activity" analysis in the sovereign immunity arena until Congress, seeing the futility of the struggle, ended it in 1976 with the passage of the Foreign Sovereign Immunities Act (FSIA). ${ }^{265}$

\section{Disagreement About Exceptions to the Doctrine}

The courts' inability to formulate a coherent standard for determining which governmental activities are considered acts of state has led some courts to resort to a mechanical approach to the act of state doctrine. This approach is exemplified by the Hunt decision of the Second Gircuit, ${ }^{268}$ to some extent by the OPEC and Clayco decisions of the Ninth Circuit, ${ }^{267}$ and by most of the various district court decisions. ${ }^{268}$ Under this approach courts cease to determine on a case-by-case basis what activities rise to the level of an act of state. Instead, any foreign governmental involvement in an international transaction will automatically trigger application of the doctrine, unless the case falls within some recognized exception. ${ }^{269}$ The problem with this approach, however, is that the courts, including the Supreme Court, have not agreed on which exceptions to the doctrine should be recognized.

\section{a. The Bernstein Exception}

The most widely debated, and perhaps the oldest, exception to the act of state doctrine is the Bernstein exception. Taking its name from a famous 1954 Second Circuit case, Bernstein v. N.V. NederlandischeAmerikaansche Stoomvaart-Maatschappij, ${ }^{270}$ the exception precludes

${ }^{265} 28$ U.S.C. $\$ \S 1330,1332(a)(2)-(4), 1391(f), 1441(d), 1602-1611$ (1982). For a description of the FSIA, see supra text accompanying notes 312-18.

${ }^{263}$ See supra notes $119-23$ and accompanying text.

${ }^{267}$ See supra notes 147-93 and accompanying text.

${ }_{288}$ See, e.g., MOL, Inc. v. Peoples Republic of Bangladesh, 572 F. Supp. 79, 83 (D. Or. 1983), affd, 736 F.2d 1326 (9th Cir.), cert. denied, 105 S. Ct. 513 (1984); Occidental Petroleum Corp. v. Buttes Gas \& Oil Co., 331 F. Supp. 92, 113-14 (C.D. Cal. 1971), affd, 461 F.2d 1261 (9th Cir.) (per curiam), cert. denied, 409 U.S. 950 (1972).

289 Note, however, Justice Marshall's statement in his dissent in Dunhill that "[t]he carving out of broad exceptions to the [act of state] doctrine is fundamentally at odds with the careful case-by-case approach adopted in Sabbatino." Dunhill, 425 U.S. at 728 (Marshall, J., dissenting); accord Sage Int'l Ltd. v. Cadillac Gage Co., 534 F. Supp. 896, 905 (E.D. Mich. 1981) (suggesting the adoption of a "flexible case-by-case approach").

${ }^{270} 210$ F.2d 375 (2d Cir. 1954). Bernstein, a German Jew, brought suit in the United States after World War II to recover properties expropriated by the Nazis during the war. In the first case brought by plaintiff, Bernstein v. Van Heyghen Freres Societe Anonyme, 163 F.2d 246 (2d Cir.), cert. denied, 332 U.S. 772 (1947), the Sec- 
application of the act of state doctrine if the State Department issues a letter informing the court that the executive branch deems application of the doctrine unnecessary.

The Bernstein exception has never been accepted by a majority of the Supreme Court. ${ }^{271}$ Nevertheless, lower courts have tended to follow the Executive's act of state recommendations automatically; ${ }^{272}$ indeed, many courts mechanically apply the doctrine unless the Executive issues a "Bernstein letter." miserly about issuing these letters. ${ }^{274}$ Moreover, in reaction to the

ond Circuit refused to hear the claim because of the act of state doctrine. See id. at 25152. Bernstein then filed a second complaint, against a different entity but based on the same acts of expropriation. In response, the Second Circuit ordered him to refrain from alleging matters that would require the court to judge the validity of acts by the official Nazi German government during World War II. Bernstein v. N.V. NederlandscheAmerikaansche Stoomvaart-Maatschappij, 173 F.2d 71, 75-76 (2d Cir. 1949), amended, 210 F.2d 375 (2d Cir. 1954). Thereafter, Bernstein was able to obtain a letter from the State Department declaring that it was the Executive's policy to relieve American courts from the restraints of the act of state doctrine in cases involving Nazi expropriations.

Upon receipt of this communication, the Second Circuit amended its initial order and allowed Bernstein to proceed with his action. See 210 F.2d at 375-76. Hence, the term "Bernstein letter" is now used to refer to a communication from the State Department informing a court that it has no objection to a decision on the merits.

${ }_{271}$ The Supreme Court in Sabbatino expressly avoided ruling on the validity of the Bernstein exception. See Sabbatino, 376 U.S. at 420. In Citibank, the Bernstein exception garnered only three votes, see 406 U.S. at 776-77; the other Justices of the majority preferred to decide the case on other grounds, see id. at 773-76 (Powell, J., concurring in the judgment); $i d$. at 770-73 (Douglas, J., concurring in the result). Of particular interest is Justice Brennan's dissent in Citibank, in which he strongly rebuked the plurality Justices for accepting the Bernstein exception. See 406 U.S. at 79093. In Dunhill, the Court chose to ignore the advice of the Executive by failing to adopt the commercial activity exception. For criticism of the Bernstein exception, see infra notes 305-09 and accompanying text.

272 See, e.g., Bernstein, 210 F.2d at 375-76; Banco Nacional de Cuba v. Sabbatino, 307 F.2d 845, 857-58 (2d Cir. 1962), rev'd, 376 U.S. 398 (1964). Compare Banco Nacional de Cuba v. Chase Manhattan Bank, 658 F.2d 875, 884-85 (2d Cir. 1981) (Bernstein letter obtained, act of state defense not recognized) with Banco Nacional de Cuba v. Chemical Bank, 658 F.2d 903, 911 (2d Cir. 1981) and First Nat'l Bank of Boston (Int'l) v. Banco Nacional de Cuba, 658 F.2d 895, 902 (2d Cir. 1981), cert. denied, 495 U.S. 1091 (1982) (Bernstein letter not obtained, act of state defense recognized).

${ }_{273}$ See, e.g., Siderman v. Republic of Argentina, No. CV 82-1772-RMT (MCx) (C.D. Cal. Sept. 28, 1984), dismissed, No. GV 82-1772-RMT (MCx) (G.D. Cal. Mar. 7, 1985), discussed in Note, Human Rights: Jurisdiction over Foreign States Under the Alien Tort Claims Act, 26 HARv. INT'L L.J. 594 (1985); Ethiopian Spice Extraction Share Co. v. Kalamazoo Spice Extraction Co., 543 F. Supp. 1224, 1229 (W.D. Mich. 1982), rev'd sub nom. Kalamazoo Spice Extraction Co. v. Provisional Military Gov't of Socialist Ethiopia, 729 F.2d 422 (6th Cir. 1984). For a further discussion of the Siderman litigation, see Bazyler, Litigating the International Law of Human Rights in United States Courts: Siderman v. Republic of Argentina, INT'L PRAC. Notebook, July 1985, at 1.

${ }^{274}$ Since 1954, when the original Bernstein letter was issued, the State Department has received approximately two to three requests a year for such letters. Accord- 
lower courts' tendency to treat the absence of a Bernstein letter as a mandate to apply the act of state doctrine, the State Department announced in the 1982 Robinson letter ${ }^{275}$ that, in cases in which there is an applicable legal standard, courts should not construe the nonissuance of a Bernstein letter as a signal that the Executive wants the act of state doctrine to be applied. ${ }^{276}$ The clear implication of this statement is that in the future the State Department will be even more reluctant to issue Bernstein letters. Thus, the courts-especially the lower federal courts-can no longer rely on the issuance or nonissuance of a Bernstein letter as a major factor in deciding whether to apply the act of state doctrine. For all practical purposes, the Robinson letter may have been the death-knell of the Bernstein exception. ${ }^{277}$

\section{b. The Commercial Activity Exception}

Another often-applied limitation on the act of state doctrine is the commercial activity exception. ${ }^{278}$ If a court characterizes the activity at issue as commercial, then the exception will foreclose application of the doctrine even if the activity is directly conducted by the sovereign. ${ }^{278}$ The Supreme Court in Dunhill, however, could not agree on whether to recognize this exception. ${ }^{280}$ The circuits are likewise divided on the

ing to an official of the State Department, they have been issued in only seven instances. Telephone conversation with John Schwartz, Office of Legal Adviser, U.S. Dept. of State (Mar. 20, 1985).

275 See supra notes $242-47$ and accompanying text.

${ }^{278}$ The State Department expressed its position in the following terms:

As a general rule, ... where there is a controlling legal standard for compensation we would not plan to inform the courts of the absence of foreign policy objections to adjudication of expropriation claims. Therefore, we would anticipate that silence on the part of the Executive in such cases would not be relied upon as a basis for judicial abstention under the Act of State Doctrine.

Robinson letter, supra note 243, at 208.

277 Of course, the Executive may continue to influence the judiciary through the filing of amicus briefs. For example, in Allied Bank v. Banco Credito Agricola de Cartago, 757 F.2d 516 (2d Cir. 1985), the State Department filed an amicus brief urging the Second Circuit to decide the case on the merits. The Second Circuit did so, reversing both the district court and its own earlier decision. For a discussion of this case, see infra note 300.

${ }^{278}$ See, e.g., Dunhill, 425 U.S. at 695-706; OPEC, 649 F.2d at 1360; Hunt, 550

F.2d at 73. For a history and analysis of the commercial activity exception, see Zaitzeff \& Kunz, The Act of State Doctrine and the Allied Bank Case, 40 Bus. Law. 449, 464-69 (1985).

279 See authorities cited supra note 278 .

${ }^{280}$ Only Chief Justice Burger and Justices Powell and Rehnquist joined the part of Justice White's opinion in Dunhill that recognized the commercial activity exception. See Dunhill, 425 U.S. at 684. 
issue, ${ }^{281}$ at least one of them internally. ${ }^{282}$

\section{c. The Treaty Exception}

The treaty exception, which derives from Justice Harlan's caveat to the holding in Sabbatino, provides that the act of state doctrine should not be applied if the issue is governed by a "treaty or other unambiguous agreement regarding controlling legal principles."283 In such circumstances the "treaty or other unambiguous agreement" should control, despite any potential repercussions to United States foreign policy interests.

Until recently, the courts showed little enthusiasm for this exception. In Libyan American Oil Co. v. Socialist People's Libyan Arab Jamahirya, ${ }^{284}$ for example, a district court in the District of Columbia refused to enforce an arbitration award that the plaintiff obtained against Libya through a previously agreed-upon arbitration proceeding. The clear implication of Libyan American Oil was that a sovereign may violate an unambiguous treaty or agreement applicable to a commercial transaction without its actions being questioned by the American courts. ${ }^{285}$

Similarly, in Ethiopian Spice Extraction Share Co. v. Kalamazoo Spice Extraction Co., ${ }^{286}$ a district court in Michigan refused to allow an American company to recover damages for the uncompensated expropriation of its holdings in Ethiopia, despite the existence of a treaty between Ethiopia and the United States that prohibited the taking of property without a " "prompt payment of just and effective compensation." "287 The court found that the terms of the treaty were "inherently general, doubtful, and susceptible of multiple interpretation," and refused to invoke the treaty exception. ${ }^{288}$

281 Compare Hunt, 550 F.2d at 73 (Second Circuit's recognition, in dicta, of the exception) with OPEC, 649 F.2d at 1360 (Ninth Circuit's rejection of the exception).

${ }^{282}$ See supra note 174; see also Braka v. Bancomer, S.N.C., 762 F.2d 222, 225 (2d Cir. 1985) (emphasizing that the statements in Hunt were dicta and leaving open "for another day" the existence of a commercial activity exception in the Second Circuit).

${ }^{283}$ Sabbatino, 376 U.S. at 428. 1981).

284482 F. Supp. 1175 (D.D.C. 1980), vacated mem., 684 F.2d 1082 (D.C. Cir.

28B See id. at 1178-79.

${ }^{288} 543$ F. Supp. 1224 (W.D. Mich. 1982), rev'd sub nom. Kalamazoo Spice Extraction Co. v. Provisional Military Gov't of Socialist Ethiopia, 729 F.2d 422 (6th Cir. 1984).

${ }^{287}$ Id. at 1230 (quoting Treaty of Amity and Economic Relations, Sept. 7, 1951, United States-Ethiopia, art. VIII, § 2, 4 U.S.T. 2134, T.I.A.S. No. 2864).

288 Id. 
The Sixth Gircuit, however, reversed the district court. ${ }^{289}$ Citing Justice Harlan's caveat in Sabbatino, the court held that the AmericanEthiopian treaty precluded application of the act of state doctrine to the Ethiopian government's expropriation. ${ }^{290}$

In resurrecting the treaty exception, ${ }^{291}$ the Sixth Circuit was probably influenced by strong encouragement it received from the Executive and the private bar. The State Department issued the Robinson letter; the State, Justice, and Treasury Departments filed a joint amicus brief; and the American Bar Association filed a brief as well. ${ }^{292}$ In the face of such an onslaught of arguments, all urging recognition of the treaty exception, it is no wonder that the Sixth Circuit reversed the district court and recognized the exception.

\section{d. The Fraud Exception}

The fraud exception is applied to cases in which acts of a foreign government were induced by fraud or corruption. ${ }^{293}$ Lately, however, the exception has not been well received by the courts. The Ninth Circuit in Clayco expressly rejected the exception in the context of a private suit, ${ }^{294}$ and both the Sixth Circuit, in Compania de Gas de Nuevo Laredo, S.A. v. Entex, Inc., ${ }^{295}$ and the Second Circuit, in Hunt, ${ }^{296}$ specifically declined to address the merits of the exception.

\section{e. The United States Property Situs Exception}

A more recent development in the act of state doctrine is the . United States property situs exception. ${ }^{297}$ This exception-which has its origins in Judge Friendly's opinion in a 1965 case, Republic of Iraq v. First National City Bank ${ }^{288}$-applies to international disputes involving expropriated property located in the United States. American

280 Kalamazoo Spice Extraction Co. v. Provisional Military Gov't of Socialist Ethiopia, 729 F.2d 422 (6th Gir. 1984).

280 See id. at 427-28.

291 The court, in an appendix to the opinion, listed other treaties which likewise would support a treaty exception to the act of state doctrine. See id. at 428-30.

292 See id. at $422,425$.

${ }^{293}$ See Sage Int'l Ltd. v. Cadillac Sage Co., 534 F. Supp. 896, 909-10 (E.D. Mich. 1981); Dominicus Americana Bohio v. Gulf \& Western Indus., 473 F. Supp. 680, 690 (S.D.N.Y. 1979).

294 See Clayco, 712 F.2d at 409.

285686 F.2d 322, 326 (5th Cir. 1982).

286 See 550 F.2d at 79.

297 For discussions of the history of the exception, see Zaitzeff \& Kunz, supra note 278, at 451-58; Note, The Resolution of Act of State Disputes Involving Indefinitely Situated Property, 25 VA. J. INT'L L. 901, 907-26 (1985).

298353 F.2d 47 (2d Cir. 1965), cert. denied, 382 U.S. 1027 (1966). 
courts invoking this exception will apply the act of state doctrine to disputes involving such property only if the foreign government's act of expropriation is consistent with American policy and law. ${ }^{299}$ Since foreign acts of expropriation inevitably conflict with the fifth amendment's prohibition against uncompensated governmental takings, this exception invariably precludes application of the act of state doctrine when the expropriated property or its proceeds are located in the United States.

This exception has not often been invoked, since property expropriated by a foreign government rarely is found in the United States. On a theoretical level, however, the exception undercuts one of the most frequently cited rationales for the application of the act of state doctrine, namely, that the doctrine should be invoked to prevent embarrassment to the Executive in its conduct of foreign policy. The invocation of the property situs exception does not depend on whether adjudication of the claim could vex relations with foreign nations. Since the same potential for executive embarrassment exists when an American court adjudicates rights to expropriated property located in the United States as when it decides rights to expropriated property located in a foreign country, no reason exists why potential for executive embarrassment should preclude adjudication of the latter but not the former claim. The property situs exception therefore exposes the weakness of the "embarrassment to our foreign policy" rationale for the act of state doctrine. If foreign expropriation claims can be adjudicated in American courts when the property is located in the United States, without concern for foreign policy implications, then all expropriation claims should be so adjudicated. ${ }^{300}$

\section{f. The Human Rights Exception}

A final, as yet unapplied, exception to the act of state doctrine is

${ }^{289} \mathrm{See} i d$. at 51 . This idea has been codified in the FSIA as a recognized exception to sovereign immunity. See 28 U.S.C. $\$ 1605$ (a)(3) (1982).

300 The inconsistent application of this exception, as well as the other exceptions to the act of state doctrine, was recently illustrated in Allied Bank v. Banco Credito Agricola de Cartago, 757 F.2d 516 (2d Cir. 1985). In Allied Bank, a consortium of American banks sued three Costa Rican banks for failure to pay amounts due on promissory notes in the United States. It seemed clear that the "United States property situs" exception should apply, since the situs of the debt was in the United States. See Zaitzeff \& Kunz, supra note 278, at 473-83. Moreover, a district court in a nearly identical case, Libra Bank v. Banco Nacional de Costa Rica, 570 F. Supp. 870 (S.D.N.Y. 1983), had invoked the exception. See id. at 881-83. However, in Allied Bank both the district court and the Second Circuit refused to apply the exception until the Executive filed an amicus brief suggesting that the exception be applied. See 757 F.2d at 519. Allied Bank, therefore, illustrates that the property situs exception may depend on the position taken by the Executive. The same is true of the other exceptions discussed above. 
the human rights exception. The sixth tentative draft of the Restatement of Foreign Relations Law of the United States (Revised) explains the exception as follows:

A claim arising out of an alleged violation of fundamental human rights-for instance, a claim on behalf of a victim of torture or genocide-would (if otherwise sustainable) probably not be defeated by the act of state defense, since the accepted international law of human rights is both well established and contemplates external scrutiny of such acts. ${ }^{301}$

To date, no court has explicitly recognized this exception, ${ }^{302}$ and its tentative inclusion in the revised Restatement probably is due more to the personal predilections of the Chief Reporter, Professor Louis Henkin, than to its general acceptance in the law. ${ }^{303}$

The foregoing review of exceptions to the act of state doctrine shows widespread disagreement not only about the scope but even

so1 Restatement (Revised) of Foreign Relations LaW of the United StATes § 469, at 361 (Tent. Draft No. 6, 1985). The American Law Institute (ALI) adopted the Restatement (Second) of Foreign Relations Law of the United States in 1962 and promulgated it with revisions in 1965. In the late 1970's, the ALI began a further revision of the Restatement, to be titled, in its final form, Restatement (Revised). By the time of the ALI's annual meeting in May 1985, six tentative drafts had been issued. The last draft, Tentative Draft No. 6, contains new sections 469 and 470 , dealing with the act of state doctrine; these supersede the act of state provisions in sections 428 and 429 of Tentative Draft No. 4, issued in April 1983. Final action on the Restatement (Revised) has been postponed until May 1986. See Hoyt, Chairman's Column, INT'L L. News, Summer 1985, at 1, 7.

The revision maintains an active act of state doctrine, such as that described in Sabbatino and OPEC. This aspect of the revision has been sharply criticized. See Halberstam, Sabbatino Resurrected: The Act of State Doctrine in the Revised Restatement of U.S. Foreign Relations Law, 79 AM. J. INT'L L. 68 (1985); Restatement of Foreign Relations Law: Council Meets with ALI Reporters, INT'L L. News, Winter 1984 , at $1,9$.

${ }_{302}$ Two cases have implicitly recognized the human rights exception. In Filartiga v. Pena-Irala, 630 F.2d 876, 889 (2d Cir. 1980), the Second Circuit, in dictum, expressed its doubt that torture perpetrated by a state official, in violation of the law of the foreign state and unauthorized by its government, could properly be characterized as an act of state. The ResTATEMENT (REvisED), supra note 301, $\$ 469$ note 3, cites Filartiga in support of a human rights exception. In Siderman v. Republic of Argentina, No. CV 82-1772-RMT (MCx) (C.D. Cal. Sept. 28, 1984), dismissed, No. GV 82-1772-RMT (MCx) (C.D. Cal. Mar. 7, 1985), the district court dismissed on act of state grounds a claim based on foreign expropriation of property but allowed the plaintiffs to proceed with claims based on torture. The court thus impliedly recognized that torture claims cannot be defeated by the act of state doctrine, although it thereafter dismissed the claims on sovereign immunity grounds. See Siderman v. Republic of Argentina, No. CV 82-1772-RMT (MCx) (C.D. Cal. Mar. 7, 1985), discussed in Note, supra note 273.

s03 A representative expression of Professor Henkin's views may be found in Henkin, Human Rights and "Domestic Jurisdiction," in Human RIGHTS, INTERnAtional LAW and tHe Helsinki AcCord 21 (T. Buergenthal ed. 1977). 
about the recognition of each exception. This confusion is understandable. If courts cannot agree on the proper scope of a doctrine, it is not surprising that they cannot agree on the exceptions to it.

One result of this confusion is added uncertainty for parties considering international transactions. Being unable to predict whether a dispute arising from such transactions will be adjudicable in United States courts, they may be reluctant to take on this additional risk and discouraged from entering international commerce.

\section{B. Violating the Separation of Powers Doctrine}

Another major failing of the act of state doctrine is that its application often violates the constitutionally required separation of powers between the executive, legislative, and judicial branches of the government. The separation of powers doctrine contemplates that courts will decide cases independently and without direction or influence from the executive or legislative branches. The bulwark of our democracy is an independent judiciary. ${ }^{304}$

The act of state doctrine, as applied by American courts, violates this separation of powers and interferes with judicial independence. As part I of this Article has shown, courts are unduly sensitive to the Executive's views on whether the act of state doctrine should be applied in particular cases. On occasion, they have even requested instruction from the Executive on whether to apply the doctrine. ${ }^{305}$ In terms of the Executive's interests, this may make some sense. As Justice Rehnquist pointed out in his plurality opinion in Citibank, a major reason for applying the act of state doctrine is to avoid interference with the Executive's conduct of foreign policy. ${ }^{906}$ If the Executive informs the court that the case before it does not interfere with United States foreign policy, then this rationale, at least, would not justify application of the doctrine. ${ }^{307}$ Such dependence on a pronouncement from the Executive, however, allows the Executive in effect to replace the court as the decisionmaker in the case. This, of course, diminishes the independence of the judiciary and tarnishes its image. ${ }^{308}$ It is an embarrassment that American federal courts, so independent in other areas, are so subservient to the Executive where the act of state doctrine is concerned. ${ }^{309}$

\footnotetext{
304 See supra notes 11-12 and accompanying text.

${ }^{305}$ See supra note 274.

${ }^{308}$ See Citibank, 406 U.S. at 765-67.

sor See id. at 768-69.

sos See id. at 790 (Brennan, J., dissenting) (Blind adherence to the Executive's requests concerning application of the act of state doctrine "politicizes the judiciary.").

sog The Second Circuit recently furnished some dramatic examples of embarrass-
} 
Faced with similar deference in the sovereign immunity area, Congress passed the Foreign Sovereign Immunities Act to prevent the Executive from dictating results in cases in which sovereign immunity is raised as a defense. Unfortunately, the independence restored by the FSIA is lost when the judiciary bows to the executive will on act of state grounds.

\section{Impairing the Effectiveness of United States Laws}

The act of state doctrine has undermined laws of major importance in the international arena: the Federal Sovereign Immunities $\mathrm{Act}^{\mathbf{3 1 0}}$ and federal antitrust law. In addition, two other areas of law affecting international commerce-federal securities law and the Foreign Corrupt Practices Act of $1977^{311}$-might be weakened by further developments in the doctrine. Each of these laws will be discussed separately.

\section{The Foreign Sovereign Immunities Act}

In 1976, Congress codified the restrictive theory of foreign sovereign immunity by passing the Foreign Sovereign Immunities Act. The FSIA governs federal and state subject-matter jurisdiction in actions against foreign sovereigns stemming from their commercial or private law activities. ${ }^{312}$ The FSIA drafters intended that courts would look to the FSIA to decide whether a foreign sovereign could be sued. ${ }^{313}$ Despite this intention, courts now resort to the act of state doctrine to avoid adjudication even when the FSIA mandates it. ${ }^{\mathbf{3 1 4}}$

ing judicial deference. In 1981, a Second Circuit panel had before it two similar cases. Both involved counterclaims by American banks against Cuba that were based on the nationalization of the banks' Cuban assets. The court allowed the first bank's claim to proceed because it had obtained a Bernstein letter from the State Department. See Banco Nacional de Cuba v. Chase Manhattan Bank, 658 F.2d 875, 884 (2d Cir. 1981). Because the second bank had failed to obtain such a letter, however, the court remanded the case to the district court for "findings as to the views of the Executive Branch." Banco Nacional de Cuba v. Chemical Bank, 658 F.2d 903, 911-12 (2d Cir. 1981). The court made it clear that without a "green light" from the Executive, in the form of a Bernstein letter, it would refrain from adjudicating foreign expropriation claims, even if the party was not making an independent claim but merely asking for a setoff against a claim by the expropriating government. Id. at 911 .

For another such example, see supra note 300 (discussing Allied Bank v. Banco Credito Agricola de Cartago, 757 F.2d 516 (2d Cir. 1985)).

s10 28 U.S.C. $\$ \S 1330,1332(\mathrm{a})(2)-(4), 1391(\mathrm{f}), 1441(\mathrm{~d}), 1602-1611$ (1982).

s11 15 U.S.C. $\$ \S 78 \mathrm{~m}(\mathrm{~b}),(\mathrm{d})(1),(\mathrm{g})-(\mathrm{h}), 78 \mathrm{dd}-1$ to $-2,78 \mathrm{ff}(\mathrm{a}),(\mathrm{c})(1982)$.

s12 The best discussion on sovereign immunity and the FSIA is Kane, Suing Foreign Sovereigns: A Procedural Compass, 34 StAN. L. Rev. 385 (1982).

s1s See FSIA House RePORT, supra note 155, at 6606.

s14 See supra notes 158-66 and accompanying text. Even prior to passage of the 
The use of the act of state doctrine when a foreign sovereign is one of the litigants negates a number of the FSIA's important policies. The Act mandates examination of the nature of a commercial activity rather than its purposes. ${ }^{316}$ If the activity is commercial in nature, then the case must be adjudicated. Using the act of state doctrine as a rationale, however, courts have circumvented this directive and have continued to examine the purpose of the activity. ${ }^{316}$ A public purpose, which can be found in almost every case involving a foreign sovereign, ${ }^{\mathbf{3 1 7}}$ precludes adjudication of the suit under the act of state doctrine. The public purpose analysis, apparently abolished by the FSIA, has thus been resurrected.

Similarly, Congress sought to abolish the courts' practice of looking to the Executive to determine whether a foreign sovereign should be immune from suit. The House Report accompanying the FSIA noted that

the foreign state may attempt to bring diplomatic influences to bear upon the State Department's determination. A principal purpose of this bill is to transfer the determination of sovereign immunity from the executive branch to the judicial branch, thereby reducing the foreign policy implications of immunity determinations and assuring litigants that these often crucial decisions are made on purely legal grounds and under procedures that insure due process. ${ }^{318}$

The continuing deference that courts give to the Executive in determining whether to apply the act of state doctrine clearly undermines these policies.

FSIA, Justice White, in Part III of his opinion in Dunhill, warned against the use of the act of state doctrine as a replacement for the doctrine of sovereign immunity: "[W]e hold that the mere assertion of sovereignty as a defense to a claim . . . is no more effective if given the label 'Act of State' than if it is given the label 'sovereign immunity." " 425 U.S. at 705 (footnote omitted).

Unfortunately, only three other justices joined in Part III of Justice White's Dunhill opinion. As a result, lower courts increasingly have ignored that part of Dunhill and found the act of state doctrine applicable when sovereign immunity was lacking. See cases cited supra note 166.

315 See 28 U.S.C. $§ 1603$ (d) (1982); FSIA House REPORT, supra note 155, at 6614-15.

316 See, e.g., Clayco, 712 F.2d at 406; OPEC, 649 F.2d at 1360; MOL, Inc. v. Peoples Republic of Bangladesh, 572 F. Supp. 79, 85 (D. Or. 1983), aff d, 736 F.2d 1326 (9th Cir.), cert. denied, 105 S. Ct. 513 (1984).

317 See supra text accompanying notes 262-65.

s18 FSIA House REPORT, supra note 155, at 6605-06. 


\section{The Antitrust Laws}

The antitrust laws are among the most important and effective provisions regulating economic activity in the United States. The purpose of these laws is to preserve "free and unfettered competition as the rule of trade." 19 Moreover, the antitrust laws have an extraterritorial effect. Section 1 of the Sherman Act, for example, contains no territorial limitation: "Every contract, combination . . . or conspiracy, in restraint of trade or commerce among the several States, or with foreign nations, is declared to be illegal." ${ }^{\mathbf{3 2 0}}$ For this reason, the Sherman Act, and with it the other antitrust laws, ${ }^{321}$ may be applied to conduct beyond United States borders so long as the conduct has a "direct and substantial effect' ${ }^{\text {'s22 }}$ on United States commerce.

Application of the antitrust laws to activities beyond our borders brings numerous benefits. First, it prevents circumvention of the antitrust laws by multinational corporations that might otherwise attempt to consummate anticompetitive transactions beyond the territorial borders of the United States. Second, it helps to protect the export opportunities of American firms, by making foreign firms subject to the same antitrust rules. Finally, by improving competition among competing importers, extraterritorial antitrust jurisdiction may spur complacent domestic industries to more competitive behavior, with resulting benefits to American consumers. ${ }^{323}$

American antitrust policy depends for enforcement not only on actions brought by the Executive, through the Federal Trade Commission or the Antitrust Division of the Department of Justice, but also on

319 Northern Pac. Ry. v. United States, 356 U.S. 1, 4 (1958); see also, e.g., R. Posner, Antitrust Law: An Economic Perspective 3 (1976) ("The basic concern of the antitrust laws is with monopoly . . ..").

32015 U.S.C \& 1 (1982).

321 Besides the Sherman Act, the other important antitrust laws are the Clayton Act, 15 U.S.C. $\$ \S 12-22,27$ (1982), the Federal Trade Commission Act, 15 U.S.C $\S \S 41-51$ (1982), and, to a lesser extent, the Robinson-Patman Act, 15 U.S.C. §§ 1313b, 21a (1982). See R. POSNER, supra note 319, at 23-31, 179-80.

${ }_{322}$ Timberlane Lumber Co. v. Bank of Am. Nat'l Trust \& Sav. Ass'n, 549 F.2d 597, 610 (9th Gir. 1976). For informative discussions of the extraterritorial application of the antitrust laws, see In re Uranium Antitrust Litig., 617 F.2d 1248, 1253-56 (7th Cir. 1980); Mannington Mills, Inc. v. Congoleum Corp., 595 F.2d 1287, 1297-98 (3d Cir. 1979); see also W. Fugate, Foreign Commerce and the Antitrust Laws 29-86 (2d ed. 1973); Dunfee \& Friedman, The Extra-Territorial Application of United States Antitrust Laws: A Proposal for an Interim Solution, 45 OHIO ST. L.J. 883 (1984); Note, Extraterritorial Application of Federal Antitrust Laws: Delimiting the Reach of Substantive Law Under the Sherman Act, 20 VAND. L. REv. 1030 (1967); Comment, Extraterritorial Application of the Antitrust Laws: A Conflict of Laws Approach, 70 YALE L.J. 259 (1960).

323 See D. Wilson, International Business Transactions in a Nutshell 125 (2d ed. 1984). 
private suits brought by aggrieved parties. ${ }^{324}$ In fact, private enforcement is encouraged by the awarding of treble damages. ${ }^{325}$ By precluding adjudication of suits brought by private parties for antitrust violations occurring outside the United States, the act of state doctrine effectively destroys this private enforcement mechanism. The Second Circuit's Hunt decision aptly illustrates how a clear violation of the antitrust laws can remain unpunished when a foreign government lurks in the background of a private lawsuit. ${ }^{328}$

\section{The Securities Laws}

The various securities laws are another important means of regulating economic activity in the United States. Passed in the aftermath of the Great Depression, these laws are designed to ensure that accurate information is provided to purchasers of securities. ${ }^{327}$ The securities laws, like the antitrust laws, have been applied to transactions outside of the United States that have a direct and substantial effect on United States commerce. ${ }^{328}$

The extraterritorial application of the securities laws clearly promotes fairness in securities transactions affecting American firms and individuals. Corporations and brokers cannot avoid the requirements of fair dealing and full disclosure simply by shifting securities transactions outside the borders of the United States.

The securities laws may be circumvented, however, if the transaction in question can be characterized as involving an act of state. If the reasoning behind the act of state decisions involving antitrust law is extended to the securities area, a foreign sovereign, or even a private litigant in conjunction with a foreign sovereign, could probably violate the securities laws with impunity. The doctrine, therefore, has the po-

s24 See 15 U.S.C. $\S 15$ (a) (1982); R. PoSNER, supra note 319, at 31-35; L. SuLLIVAN, HaNdBoOK OF THE LAW OF ANTITRUST 751-96 (1977).

32s See 15 U.S.C. § 15(a) (1982); R. PosNeR, supra note 319, at 31; L. SuluVAN, supra note 324 , at 769 .

${ }_{328}$ See supra notes $119-23$ and accompanying text.

327 Although securities transactions are subject to both federal and state laws, the federal regulatory scheme is more important. Federal securities law consists primarily of six statutes enacted between 1933 and 1940, and one enacted in 1970. Of the six, the two most important are the Securities Act of 1933, 15 U.S.C. $\$ \S 77 a-77 b b b b(1982)$, and the Securities Exchange Act of 1934, 15 U.S.C. $\$ \S 78 \mathrm{a}-78 \mathrm{kk}$ (1982). See generally T. Hazen, The Law of Securities Regulation (1985).

328 See, e.g., Continental Grain v. Pacific Oilseeds, Inc., 592 F.2d 409, 420-21 (8th Cir. 1979); Bersch v. Drexel Firestone, Inc., 519 F.2d 974, 999 (2d Cir.), cert. denied, 423 U.S. 1018 (1975); Travis v. Anthes Imperial Ltd., 473 F.2d 515 (8th Cir. 1973); Leasco Data Processing Equip. Corp. v. Maxwell, 468 F.2d 1326 (2d Cir. 1972). 
tential to emasculate the securities laws as they affect extraterritorial transactions. ${ }^{328}$

\section{The Foreign Corrupt Practices Act}

Another important federal law regulating the practice of American business in the international marketplace is the Foreign Corrupt Practices Act of 1977 (FCPA). ${ }^{330}$ The FGPA prohibits the payment of bribes by American businesses to officials of foreign governments ${ }^{331}$ on the grounds that such activities hurt rather than help our foreign commerce. ${ }^{332}$ The executive branch, through the Justice Department, enforces the Act by bringing suit against the American offender. ${ }^{333}$ The FCPA has also been interpreted to include a private enforcement mechanism that permits private parties to file suit for damages. ${ }^{334}$

Private litigants may find, however, that their suits are barred by the act of state doctrine. Since the violation is, by definition, a payment to a foreign official, inherent in every private suit under the FCPA is the involvement of a foreign government. Adjudicating FCPA enforce-

329 Beyond the antitrust and securities laws, the act of state doctrine has the potential of severely limiting any United States law that contains an extraterritorial component. For instance, in Vanity Fair Mills, Inc. v. T. Eaton Co., 234 F.2d 633 (2d Cir.), cert. denied, 352 U.S. 871 (1956), the Second Circuit restricted enforcement of the United States trademark laws because of the act of state doctrine. The court held that the defendants' possession of a Canadian trademark registration prevented it from examining an alleged infringement of the plaintiff's similar United States trademark. The court limited application of the trademark laws even though it acknowledged that (1) such laws reach conduct abroad that has a substantial effect in the United States and (2) the defendants' conduct had such an effect. See id. at 642. But see American Rice, Inc. v. Arkansas Rice Growers Coop. Ass'n, 701 F.2d 408, 416 (5th Cir. 1983) (asserting that the act of state doctrine does not bar extraterritorial copyright infringement actions).

sso 15 U.S.C. $\S \S 78 \mathrm{~m}(\mathrm{~b}),(\mathrm{d})(1)$, (g)-(h), 78dd-1 to $-2,78 \mathrm{ff}(\mathrm{a})$, (c) (1982). For more extensive discussions of the FCPA, see Baruch, The Foreign Corrupt Practices Act, 57 Harv. Bus. Rev. 32 (1979); Surrey, The Foreign Corrupt Practices Act: Let the Punishment Fit the Crime, 20 HARv. INT'L L.J. 293 (1979); Note, The Foreign Corrupt Practices Act of 1977: An Analysis of Its Impact and Future, 5 B.C. INT'L \& Comp. L. Rev. 405 (1982); Comment, The Foreign Corrupt Practices Act of 1977, 27 U. KaN. L. Rev. 635 (1979).

ss1 15 U.S.C. $\$ \S 78 \mathrm{dd}-1$ to -2 (1982).

s92 H.R. ReP. No. 831, 95th Cong., 1st Sess. 12, reprinted in 1977 U.S. CoDE CoNG. \& AD. NEwS 4121.

sss 15 U.S.C. § 78dd-2(c) (1982).

ss4 See Notification of Enactment of Foreign Corrupt Practices Act of 1977, [Accounting Series Releases 1937-1982 Transfer Binder] Fed. SEc. L. REP. (CGH) II 72,264, at 62,699-702 (Feb. 16, 1978); Letter from Frederick B. Wade, Special Counsel of the SEG, to Raymond Garcia (May 16, 1978) (discussing the FCPA's contemplation of a private right of action), reprinted in 1 FOREIGN CORRUPT PRAC. ACT REP. (BusINess Laws, INC.) 213; Siedel, Internal Accounting Controls Under the Foreign Corrupt Practices Act: A Federal Law of Corporations?, 18 AM. Bus. L.J. 445, 471 (1981). 
ment actions will nearly always require an examination of the reasons for the payment and the motivation of the foreign official in accepting the payment. Courts might therefore invoke the act of state doctrine as a convenient excuse to avoid deciding difficult FCPA cases. ${ }^{335}$

\section{Impeding the Development of International Law in the United States}

In the view of many international legal scholars, the greatest damage done by the act of state doctrine has been to inhibit the development of international law in the United States. ${ }^{336}$ The most important goal of international legal scholars and organizations has been to promote the rule of law in the international arena. ${ }^{337} \mathrm{~A}$ well-defined and widely followed international legal order will lead, it is hoped, to the peaceful resolution of disputes among nations. ${ }^{338}$ The United $\mathrm{Na}$ tions $^{\mathbf{3 s 9}}$ and the International Court of Justice ${ }^{\mathbf{3 4 0}}$ were created specifically for this purpose.

Not long after the creation of these international bodies, however, it became clear, even to their most ardent supporters, that they were not fulfilling these expectations. Neither the United Nations ${ }^{341}$ nor the

sso See, e.g., Clayco, 712 F.2d at 407 (discussing adjudication of a claim based on bribery of foreign sovereign). Alternatively, a court might conclude that bribery in violation of the foreign state's own laws does not constitute an "act of state" and thus refuse to invoke the doctrine. Cf. Filartiga v. Pena-Irala, 630 F.2d 876, 889 (2d Cir. 1980) (expressing doubt that torture perpetrated by a state official, in violation of the law of the foreign state and unauthorized by its government, could properly be characterized as an act of state).

sse See, e.g., Wallace, Abolishing or Changing the Act of State Doctrine by Legislation: Comments, in ACT of STATE AND EXTRATERRITORIAL REACH 25, 25 (J. Lacey ed. 1983) ("If there were no Act of State doctrine, international law would come in.").

s37 See J. SweEney, C. OlIVer \& N. Leech, supra note 61, at 1 (There is an "urgent need for the growth of [international] order beyond the rules that have developed in the West."); Inside ABA: News Update, A.B.A. J., June 1984, at 141 (advancing the rule of law in the world is an ABA goal); see also U.N. CHARTER preamble (announcing purpose "to establish conditions under which justice and respect for the obligations arising from treaties and other sources of international law can be maintained").

sss See U.N. ChaRTER preamble.

sse See id. at preamble, art. I; 1 L. Gross, The United Nations and the Role of Law, in EsSAYS ON INTERNATIONAL LAW AND ORGANIZATION 159, 163-71 (1984). so G.A. Res. 171 (II), U.N. Doc. A/459, at 1559 (1947); Dillard, The World Court: Reflections of a Professor Turned Judge, 27 AM. U.L. REv. 205, 242-43 (1978).

si1 See, e.g., J. Halderman, The United Nations aNd the Rule of Law 1 (1966) ("Although the United Nations was intended to serve . . . as the framework of [a system capable of maintaining peace], its potential in this respect is today virtually written off."); E. LuaRd, The United Nations: How It Works AND What IT Does 1-8 (1979) ("Has the U.N. failed?"); id. at 154-71 ("Can the System be Re- 
International Court of Justice ${ }^{342}$ has been used extensively to resolve international disputes; consequently, these bodies have been unable to create a widely followed international rule of law.

For this reason, international legal scholars have looked to various domestic institutions as a means to promote international law. One such institution, found in every nation, is the domestic court. Promoting and developing the rule of law is the court's function, and it can perform this function not only with domestic law but also with international law. In 1964, Professor Richard Falk, in his monumental treatise, The Role of Domestic Courts in the International Legal Order, presented the thesis that domestic courts, in dealing with cases that involve the international arena, act as agents of the international legal order. ${ }^{343}$ According to Falk, and later to others, ${ }^{344}$ the attitude that domestic courts take with respect to international law will determine whether international law develops or stagnates. ${ }^{345}$ Because the United States is a superpower and the American judicial system is highly respected in the rest of the world, the American courts' treatment of international law takes on a special significance.

formed?"); J. SWEENEY, C. OlIVER \& N. LEECH, supra note 61, at 1299-1300 ("What went wrong?").

s42 See, e.g., J. Sweeney, C. Oliver \& N. Leech, supra note 61, at 70 ("The unwillingness of States to resolve their disputes by referring them to the court has caused concern about its future."). See generally J. Gamble, JR. \& D. Fischer, The INTERNATIONAL CoURT OF JUSTICE: AN ANALYSIS OF A FaIluRe 1-5, 11-27 (1976). Some of the most recent efforts of the International Court of Justice have also met with failure. In 1979, Iran refused to recognize the court's order to release the American hostages held at the U.S. Embassy in Teheran. J. SwEEnEY, C. OLIVER \& N. LEECH, supra note 61 , at 70 . In 1985 , the United States refused to submit to the court's jurisdiction in order to prevent the court from adjudicating the legality of American intervention in Nicaragua, United States: Statement on the U.S. Withdrawal from the Proceedings Initiated by Nicaragua in the International Court of Justice, 24 INT'L LEGAL MATERIALS 246-63 (1985); Kempster \& Hager, U.S to Boycott World Court Nicaragua Case, L.A. Times, Jan. 19, 1985, at 1, col. 3, and later withdrew its acceptance of compulsory jurisdiction from the court, see Effron, Critics Lambast Reagan Pull-Back From World Court, L.A. Daily J., Oct. 11, 1985, at 1, col. 6.

343 See R. FALK, supra note 4. Professor Falk's other writings in this area include R. Falk, The Status of Law In InTERnational Society 525 (1970); Falk, The Interplay of Westphalia and Charter Conceptions of International Legal Order, in The Future of the International Legal Order 32, 69 (R. Falk \& C. Black eds. 1969).

st4 See Friedmann, National Courts and the International Legal Order: Projections on the Implications of the Sabbatino Case, 34 GEo. WASH. L. REV. 443 (1966); Lillich, supra note 48, at 12-27, 37-50; Note, Limiting the Act of State Doctrine, supra note 2, at 122-26; see also Citibank, 406 U.S. at 775 (Powell, J., concurring in the judgment) (stating that hope for defining an international "act of state" doctrine will be lost if the task is "relegated to political rather than judicial processes").

345 According to Professor Falk, "[d]omestic courts provide an excellent arena within which to exhibit either a scornful or a constructive attitude toward the relevance of international law to international behavior." $\mathrm{R}$. FALK, supra note 4, at 12 . 
Unfortunately, by applying the act of state doctrine, American courts have engaged in "judicial abdication"s46 of their responsibility for resolving international law issues. ${ }^{347}$ In contrast, the domestic courts of other nations have long taken an active role in the use and development of international law. ${ }^{348}$ The failure of American courts to do so has caused irreparable harm to the reputation of international law and to its continued development.

Justice Powell, in his concurring opinion in Citibank, made this point succinctly:

[U]ntil international tribunals command a wider constituency, the courts of various countries afford the best means for the development of a respected body of international law. There is less hope for progress in this long-neglected area if the resolution of all disputes involving an "act of state" is relegated to political rather than judicial processes. ${ }^{349}$

Continued resort by American courts to the act of state doctrine to avoid deciding international law issues dims the hope of Justice Powell and others that the American judiciary will help to develop a respected

${ }^{348}$ In 1970, Professor Lillich characterized domestic courts in the United States as being in "a period of 'judicial abdication' to the executive branch in cases involving international law issues." Lillich, supra note 48 , at 11 . Lillich concluded that "domestic courts have revealed substantial ingenuity in avoiding the necessity of deciding international law cases where the local sovereign's conduct has been called into question." Id. at 48 (footnote omitted).

A decade later, in 1980, Senator Mathias also concluded that American courts, in applying the act of state doctrine, are "shirking a responsibility taken on by other judiciaries around the world [and] announc[ing] that they will take no part in the development or application of international law." Mathias, supra note 2, at 414. See also Act of State Hearings, supra note 10, at 2 (statement of Sen. Mathias) ("Hiding behind the skirts of the act of state doctrine," courts have refused to apply international law to Cuba's expropriations.).

347 The act of state doctrine "prevents the United States from applying international law-and I do not accept the position of the Justice Department that we cannot trust our judges to develop international law." Act of State Hearings, supra note 10, at 23 (statement of Prof. Don Wallace, Jr.). The American courts have avoided international law issues despite the Supreme Court's famous statement in The Paquete Habana, 175 U.S. 677 (1900), that "[i]nternational law is part of our law, and must be ascertained and administered by the courts of justice of appropriate jurisdiction, as often as questions of right depending upon it are duly presented for their determination." Id. at 700 .

348 Justice White's dissenting opinion in Sabbatino-citing cases from England, the Netherlands, Germany, Japan, Italy, and France-states that "the executive of no other government seems to require such insulation from international law adjudications in its courts; and no other judiciary is apparently so incompetent to ascertain and apply international law." Sabbatino, 376 U.S. at 440 (White, J., dissenting) (footnote omitted). Justice Powell quoted this statement in his concurring opinion in Citibank. See 406 U.S. at 775 n.2 (Powell, J., concurring in the judgment).

349 Citibank, 406 U.S. at 775 (Powell, J., concurring in the judgment). 
body of international law..$^{350}$

\section{Alternatives to the Act of State Doctrine}

The previous sections of this Article have described a number of problems with current applications of the act of state doctrine. The doctrine fosters arbitrary and unpredictable adjudication of international disputes, undermines judicial independence, weakens the intended force of several United States laws, and arrests the development of international law by the American courts. The existence of such serious problems suggests that the doctrine should be abolished. ${ }^{351}$

Abolishing the doctrine would not strip the courts of all opportunity to forgo adjudication of cases involving international transactions; clearly, judicial abstention is sometimes appropriate. The circumstances in which restraint is proper, however, are poorly described by the term "act of state doctrine." In fact, there is no single doctrine under this heading, but rather a collection of several, often inconsistent, adjudicative principles. These principles, if applied individually, would give a narrower, more rational, and more consistent content to the concerns

sso International law is further undermined by judicial invocation of the Bernstein exception. See supra text accompanying notes 270-77. As Professor Falk warns, toleration of executive intervention in international law cases "is itself a deprecation of the commitment to international law. The prestige of international law in domestic courts is undermined if its application depends upon a prior political authorization." R. FALK, supra note 4 , at 93 .

ssi There has been much debate about whether the act of state doctrine is recognized by other nations. The debate is an important one. If other nations can survive without an American-style act of state doctrine, then perhaps the United States can do so as well.

Some have suggested that an American-style act of state doctrine exists in other judicial systems. See Sabbatino, 376 U.S. at 416 (noting that Great Britain recognized the doctrine as early as 1674); id. at $421 \mathrm{n} .21$ (stating that similar doctrine exists in both Great Britain and civil law countries). Others have argued that, while some nations may recognize an act of state doctrine, none has given it such widespread application as the United States. See Dunhill, 425 U.S. at 709-10 (State Department letter discussing trend of foreign courts to review foreign acts of state); Sabbatino, 376 U.S. at 440 (White, J., dissenting) (Courts of six nations, including Great Britain, decide cases that would be denied review on American-style act of state grounds.).

The latter view seems correct. As summarized by Senator Mathias, "[t]he United States is alone among those nations with advanced legal systems in adhering to this version of the act of state doctrine." Mathias, supra note 2, at 414. See also Act of State Hearings, supra note 10, at 22 ("[A]lmost no other country has the doctrine."); id. at 29 ("[T] he doctrine is largely unique to the United States.") (statement of Prof. Don Wallace, Jr.). Some confusion may arise because foreign courts sometimes ascribe to the act of state doctrine decisions that are actually based on the doctrine of sovereign immunity. See Wallace, Abolishing or Changing the Act of State Doctrine by Legislation: Introductory Remarks, in ACT OF STATE AND EXTRATERRITORIAL REACH 3, 6 (J. Lacey ed. 1983). In general, nations have been able to function without an American-style act of state doctrine without suffering tragic foreign policy consequences. 
now animating the act of state doctrine. ${ }^{\mathbf{s 5 2}}$

\section{A. Sovereign Immunity}

One of the most widely stated rationales for the act of state doctrine is that it prevents interference with the foreign policy of the United States and, similarly, prevents embarrassment to foreign governments in our courts. ${ }^{353}$ These same policies, however, are served by the universally accepted doctrine of foreign sovereign immunity. As previously discussed, the act of state doctrine was originally a mere extension of that doctrine. ${ }^{354}$ With the passage of the FSIA, Congress mandated that all issues pertaining to sovereign immunity, including considerations of foreign policy and political embarrassment, be decided in accordance with the terms of the Act. Since these same considerations are given to justify the act of state doctrine, the doctrine logically should be preempted by the FSIA.

The drafters of the FSIA seemed to recognize that the Act would limit the need for the act of state doctrine. They expected that, with the gradual weakening of the act of state doctrine through cases like Dunhill, the doctrine would be applicable only in very limited circumstances. ${ }^{365}$ Of course, the drafters were wrong; despite the FSIA, courts continue to use the doctrine in litigation involving foreign sovereigns.

\section{B. Forum Non Conveniens}

Forum non conveniens is a judicially created doctrine that courts use to abstain from cases that rightfully should be decided in another forum. ${ }^{356}$ Even though a case may be meritorious, a court may decline to hear it on forum non conveniens grounds if substantially all of the

352 Professor Wallace agrees with this view. "What I have tried to say is that you wouldn't open yourself up to a horrible situation by eliminating the Act of State doctrine. There would still be ways to prevent the most horrible situations, should they arise." Wallace, supra note 336 , at 25.

sss See, e.g., supra text accompanying notes 139-40, 170, 200 \& 306.

sst See supra text accompanying notes 22-34.

35s See FSIA House REPORT, supra note 155, at 6606.

358 For a thorough discussion of the doctrine of forum non conveniens in international litigation, see Note, The Convenient Forum Abroad Revisited: A Decade of Development of the Doctrine of Forum Non Conveniens in International Litigation in the Federal Courts, 17 VA. J. INT'L L. 755 (1977). For recent cases discussing the doctrine at length, and affirming dismissals on international forum non conveniens grounds, see Cheng v. Boeing Co., 708 F.2d 1406, 1409-10 (9th Cir.), cert. denied, 464 U.S. 1017 (1983); Islamic Republic of Iran v. Pahlavi, 62 N.Y.2d 474, 478-84, 467 N.E.2d 245, 247-51, 478 N.Y.S.2d 597, 599-602 (1984), cert. denied, 105 S. Ct. 783 (1985). Cheng and Pahlavi confirm the continued viability of the forum non conveniens doctrine in the international arena. 
events involved in the suit took place in another jurisdiction, if the parties are located in another jurisdiction, or if all the material evidence is located in another jurisdiction. ${ }^{357}$ No strict guidelines are established for the application of forum non conveniens. If the court believes that, in the interest of justice, it would be unfair for the defendant to undertake the burden of defense in the forum in which the case is filed, the court may decline to hear the case. ${ }^{358}$

The doctrine of forum non conveniens is particularly applicable in cases involving international transactions. ${ }^{368} \mathrm{~A}$ trial in the United States might require the defendant first to undertake discovery abroad and then to bring evidence and witnesses to the United States. An additional burden, often faced by both the defendant and the court, is the necessity of applying foreign law. ${ }^{360}$ The time and expense of undertaking such additional tasks may convince the court that it should decline to hear the case in favor of a more proper, foreign forum. ${ }^{361}$

Under this doctrine, the burden of proving forum non conveniens rests on the defendant. ${ }^{362}$ Additionally, if the plaintiff shows that the foreign forum is impractical for hearing the case, then the defendant's forum non conveniens motion will fail. ${ }^{363}$ These balancing considerations, which make the forum non conveniens doctrine more flexible than the act of state doctrine, give courts sufficient leeway to decide, on principles of justice and practicality, whether to adjudicate disputes arising from foreign transactions.

\section{In Personam Jurisdiction}

The question whether the Republic of France can be sued for a particular act is very different from the question where France may be sued. The answer to the first question depends on whether France enjoys sovereign immunity; the answer to the second depends on whether

ss7 See Cheng v. Boeing Co., 708 F.2d 1406, 1409-10 (9th Cir.), cert. denied, 464 U.S. 1017 (1983).

ss8 See id. at 1409.

s68 See Note, supra note 356 , at 755-57.

380 For a discussion of the difficulties of applying foreign law in American courts, see Merryman, Foreign Law as a Problem, 19 STAN. J. INT'L L. 151 (1983), and Sprankling \& Lanyi, Pleading and Proof of Foreign Law in American Courts, 19 STAN. J. INT'L L. 3 (1983).

s61 See Cheng v. Boeing Co., 708 F.2d 1406, 1409-10 (9th Cir.), cert. denied, 464 U.S. 1017 (1983).

s62 See 15 C. Wright, A. Miller \& E. Cooper, Federal Practice and Procedure $\S 3828$ (1976).

s6s See id.; see also, e.g., Filartiga v. Pena-Irala, 577 F. Supp. 860, 862 (E.D.N.Y. 1984) (rejecting forum non conveniens argument because further resort to Paraguayan courts to obtain relief for torture committed in Paraguay would be futile). 
France has engaged in conduct that warrants a summons before an American court. ${ }^{364}$ Failure to distinguish between these two questions may lead a court to invoke the act of state doctrine in cases in which it lacks personal jurisdiction over the defendant.

The requirement that personal jurisdiction over the defendant be consistent with constitutional due process is set out by the Supreme Court in International Shoe Co. v. Washington. ${ }^{385}$ International Shoe requires that the defendant have sufficient contacts with the forum so that assertion of personal jurisdiction would not offend notions of fair play and substantial justice. ${ }^{386}$ Hanson $v$. Denkla ${ }^{387}$ interpreted the International Shoe "minimum contacts" standard as requiring that the defendant's activities suggest that it has purposely availed itself of the privileges and benefits of the laws of the forum state. ${ }^{\mathbf{6 8}}$

The minimum contacts requirement of International Shoe remains an important tool for dismissing cases that should not have been brought in United States courts. Unlike the the act of state doctrine, with its vague "constitutional underpinnings," the International Shoe requirement is grounded solidly on the due process clause of the Constitution. Therefore, rather than jumping blindly onto the act of state bandwagon, courts should first consider the minimum contacts requirement of International Shoe. Upon closer analysis, courts may find that in many international transactions cases the defendant lacks the requisite minimum contacts with the forum. Of course, if the defendant, whether a foreign sovereign or a private party, has sufficient contacts with the United States to satisfy the due process requirements for personal jurisdiction, then this may help to convince the court that the case should be adjudicated in the United States.

\section{Choice of Law}

As discussed in part I of this Article, the original purpose of the act of state doctrine was to afford personal immunity to foreign officials who acted consistently with the laws of their jurisdiction. This use of the act of state doctrine is no more than an application of choice of law rules. $^{368}$

The typical case involving personal immunity involves acts of a foreign official in the official's own country that form the basis for a

s64 This example is taken from Kane, supra note 312 , at 396.

ses 326 U.S. 310 (1945).

366 See id. at 316 .

s67 357 U.S. 235 (1958).

${ }^{368}$ Id. at 253.

s69 See supra text accompanying notes $40-46$. 
suit brought in the United States. Assuming that the minimum contacts requirement of International Shoe has been met, the court in such a situation would need to decide under the federal choice of law analysis what law applies to the case. If all of the wrongful acts occurred in the foreign jurisdiction, choice of law rules may require that the "law of the case" be the law of the foreign jurisdiction. ${ }^{330}$

If the defendant is found not liable under the laws of the foreign jurisdiction, the court would rule in favor of the defendant. If, on the other hand, the defendant were found liable under the foreign law, then the court would grant judgment for the plaintiff. The decision to apply foreign law, as well as the ultimate disposition of the case, would be reached without any reliance on the act of state doctrine. Choice of law thus presents an additional method by which a case can be decided on other than act of state grounds.

\section{E. Foreign Sovereign Compulsion}

An additional means for a court to avoid deciding a case without resort to the act of state doctrine is through the doctrine of foreign sovereign compulsion. This doctrine, limited to antitrust cases, "is based on the theory that defendants engaged in illegal [antitrust] activity only because a foreign sovereign compelled them to do so." 371 While the doctrine has often been confused with the act of state doctrine, ${ }^{\mathbf{3 7 2}}$ it has an independent existence and may apply without regard to whether the act of state doctrine is applicable. ${ }^{373}$ The doctrine of foreign sovereign compulsion, which is based on principles of equity, relieves a party from

s70 For a discussion of the treatment of foreign law under American choice of law rules, see R. Leflar, American Conflicts Law $§ 6$ (1977). See also E. Scoles \& P. HAY, Conflict of Laws 403-14 (1984) (describing the procedures and standards applicable to the proof of foreign law).

${ }_{371}$ Timberg, Sovereign Immunity and Act of State Defenses: Transnational Boycotts and Economic Coercion, 55 TEx. L. REv. 1, 22 (1976). See generally Note, Foreign Sovereign Compulsion in American Antitrust Law, 33 Sran. L. REv. 131 (1980) (arguing that the act of state corollary provides an unfair windfall to antitrust defendants at the expense of plaintiffs).

${ }_{372}$ See Griffin, Antitrust and Act of State, in Act of STate and ExtraterriTORIAL REACH, supra note 336, at 17; Mathias, supra note 2, at 390-91. Griffin cites In re Uranium Antitrust Litig., 617 F.2d 1248, 1254 n.21 (7th Cir. 1980), as an example of a case that confused the two doctrines. See Griffin, supra, at 22.

${ }^{373}$ See Griffin, supra note 372, at 22; Mathias, supra note 2, at 391-92. Senator Mathias's bill to modify the act of state doctrine included language stating that "the act of state doctrine is conceptually and legally separate and distinct from the defense of 'foreign sovereign compulsion,'" and that the bill would not influence the effectiveness of the foreign sovereign compulsion defense. S. 1434, 97th Cong., 1st Sess. §§ 2, 5 (1981), reprinted in Act of State Hearings, supra note 10, at 3, 3-5. This language was no doubt appreciated by the antitrust bar, which strongly favors the foreign sovereign compulsion defense. See Griffin, supra note 372, at 21-22. 
choosing between two evils: acting anticompetitively, pursuant to a foreign sovereign's directive, and thus violating United States laws, or acting competitively, against the foreign sovereign's directive, thereby risking the wrath of the sovereign. The doctrine allows the private party to act anticompetitively without incurring liability under United States law.

Unlike the act of state doctrine, the foreign sovereign compulsion doctrine does not arise from fear that a decision on the merits would interfere with international politics or foreign policymaking. Rather, courts invented the doctrine to avoid the unfairness of forcing antitrust defendants to choose between two evils.

Interamerican Refining Corp. v. Texaco Maracaibo, Inc. ${ }^{374}$ is a paradigmatic foreign sovereign compulsion case. In that case, two defendant oil companies held concessions from the Venezuelan government for the production of crude oil. The oil companies were instructed by the Venezuelan government not to ship crude oil to Interamerican, an American corporation principally owned by two Venezuelan nationals who were considered personae non gratae in Venezuela. When the oil companies complied, Interamerican sued, claiming an illegal boycott. In granting summary judgment for the defendants, the district court found that the boycott was compelled by the Venezuelan authorities and that "such compulsion is a complete defense to an action under the antitrust laws based on that boycott."37s

The defense of foreign sovereign compulsion, based strictly on grounds of equity, provides a court with another means of deciding a foreign antitrust case without resort to the act of state doctrine.

\section{F. Political Question Doctrine}

A final situation in which a court could legitimately dismiss an international transaction case on other than act of state grounds arises when a case presents issues that are best resolved through the political rather than the judicial process. In such a situation, the political question doctrine is applicable.

The Supreme Court gave the political question doctrine its modern formulation in Baker v. Carr: ${ }^{376}$

Prominent on the surface of any case held to involve a political question is found a textually demonstrable constitutional commitment of the issue to a coordinate political department;

374307 F. Supp. 1291 (D. Del. 1970).

378 Id. at 1296.

376369 U.S. 186 (1982). 
or a lack of judicially discoverable and manageable standards for resolving it; or the impossibility of deciding without an initial policy determination of a kind clearly for nonjudicial discretion; or the impossibility of a court's undertaking independent resolution without expressing lack of the respect due coordinate branches of government; or an unusual need for unquestioning adherence to a political decision already made; or the potentiality of embarrassment from multifarious pronouncements by various departments on one question. $^{377}$

Cases touching on the foreign relations of the United States make up the largest class of cases to which the political question doctrine has been applied. ${ }^{378}$ For this reason, the political question doctrine is particularly well suited for application in cases that would otherwise be dismissed on act of state grounds.

The act of state doctrine, as defined by Sabbatino, incorporates the three most important criteria of the political question doctrine: (1) constitutional commitment of the issue to a coordinate branch; (2) lack of judicial standards for resolving the issue; and (3) potential for embarrassing the Executive. ${ }^{379}$ Justice Brennan, the author of Baker v. Carr, even argued in his dissenting opinion in Citibank that the act of state doctrine elaborated in Sabbatino is simply one application of the political question doctrine. ${ }^{380}$ The Ninth Circuit in OPEC similarly stated that the act of state doctrine is to be considered an "international" political question doctrine. ${ }^{381}$

If the act of state doctrine is indeed only an "international" political question doctrine, it is superfluous. The act of state doctrine, however, is not only superfluous; it also creates widespread confusion, inhibits the application of United States laws and the development of international law, and affords the courts an expedient excuse for avoiding difficult legal analysis. If a true political question is presented to a court, ${ }^{382}$ the Baker $v$. Carr factors can be applied to dismiss the case on

377 Id. at 217. For a discussion of the political question doctrine and citations to additional authorities, see L. TRIBE, supra note $11, \S 3-16$, at 71.

s78 See, e.g., Baker v. Carr, 369 U.S. at 211-14; Tel-Oren v. Libyan Arab Republic, 726 F.2d 774, 803 (D.C. Cir. 1984), cert. denied, 105 S. Ct. 1354 (1985).

s79 See, e.g., Goldwater v. Carter, 444 U.S. 996, 998 (1979) (mem.) (Powell, J., concurring); Ramirez de Arellano v. Weinberger, 745 F.2d 1500, 1511 (D.C. Gir. 1984) (en banc), vacated mem., 105 S. Ct. 2353 (1985).

s8o Citibank, 406 U.S. at 787-88 (Brennan, J., dissenting).

381 OPEC, 649 F.2d at 1358-59. A recent New York federal district court decision recognized the parallel interests of the two doctrines, treating them together in one discussion. Sharon v. Time, Inc., 599 F. Supp. 538, 547-53 (S.D.N.Y. 1984). 92.

${ }^{382}$ True political question cases are rare. See infra text accompanying notes 389- 
political question grounds. If the political question doctrine is not applicable, the court should either hear the case or articulate a specific reason, such as one of the reasons discussed above, for dismissing it. Specificity of rationale will eliminate the vague act of state pronouncements currently offered by courts to justify dismissals.

It may be asked, however, whether the proposed abolition of the act of state doctrine would result merely in a substitution of the new excuse of "political question" for the old excuse of "act of state," thereby continuing the same evils under a new rubric. Such a result is highly unlikely. Unlike the amorphous and unrestrained act of state doctrine, "[n]onjusticiability based upon 'political question' is at best a limited doctrine." ${ }^{\text {383 }}$ In Baker v. Carr the Supreme Court emphasized that the doctrine does not render all "political cases" nonjusticiable. ${ }^{384}$ The Court limited the use of the doctrine to cases that involve "primarily a function of the separation of powers."38s The opinion also noted that the doctrine in no respect requires that all issues implicating foreign affairs be ruled political questions. ${ }^{386}$

Subsequent Supreme Court ${ }^{387}$ and lower court ${ }^{388}$ decisions have

s8s Tel-Oren v. Libyan Arab Republic, 726 F.2d 774, 796 (D.C. Gir. 1984) (Edwards, J., concurring), cert. denied, 105 S. Ct. 1354 (1985). Later in his opinion, Judge Edwards explained that "the political question doctrine is a very limited basis for nonjusticiability. It certainly does not provide the judiciary with a carte blanche license to block the adjudication of difficult or controversial cases." Id. at 798. But see id. at 803 n.8 (Bork, J., concurring) (calling the political question doctrine "murky" and "unsettled"). Nevertheless, even if the contours of the political question doctrine are not precisely defined, the doctrine has been narrowly applied. The act of state doctrine, on the other hand, has been broadly applied, despite the courts' lack of understanding of it.

s84 See 369 U.S. at 209-17.

s8s Id. at 210.

388 See id. at 211.

${ }^{387}$ See Haig v. Agee, 453 U.S. 280, 292 (1981) (Matters related to foreign policy may be subject to court review.); United States v. Nixon, 418 U.S. 683, 692-97 (1974) (The dispute over the Special Prosecutor's requests for information and President Nixon's refusal to provide such information did not present a political question.); see also Goldwater v. Carter, 444 U.S. 996 (1979) (mem.) (only four Justices agreeing that a challenge by a member of Congress to the President's termination of the Taiwan treaty presents a nonjusticiable political question).

${ }_{388}$ See Langenegger v. United States, 756 F.2d 1565, 1570 (Fed. Cir.) (finding that claim for wrongful taking of plaintiff's property in El Salvador arising out of U.S. assistance in the Salvadoran agrarian reform program did not present political question), cert. denied, 106 S. Ct. 78 (1985); Ramirez de Arellano v. Weinberger, 745 F.2d 1500, 1512 (D.C. Cir. 1984) (en banc) (A deprivation of property claim stemming from American training of Salvadoran soldiers in Honduras did not present a political question.), vacated mem., 105 S. Ct. 2353 (1985); Tel-Oren v. Libyan Arab Republic, 726 F.2d 774, 796 (D.C. Cir. 1984) (Edwards, J., concurring) (stating that the political question doctrine did not apply to suits by victims of Palestinian terrorism), cert. denied, 105 S. Ct. 1354 (1985); Northrop Corp. v. McDonnell Douglas Corp., 705 
heeded the Baker $v$. Carr language cautioning against overuse of the political question doctrine, and have limited the use of the doctrine to relatively clear cases. Indeed, as one commentator has observed, ${ }^{389}$ the last time that the Supreme Court cited the doctrine in any meaningful way-other than in connection with the court challenge to President Carter's authority in the Taiwan treaty case ${ }^{\mathbf{8 0 0}}$-was in $1973,{ }^{381}$ and the last time the Court relied squarely on the doctrine was in $1946 .^{\mathbf{3 9 2}}$ Thus, the political question doctrine has both a limited and cautious heritage, and it is unlikely to undergo a radical expansion following an abolition of the act of state doctrine.

\section{Legislative Efforts to Amend the ACt of State Doctrine}

One indication that the act of state doctrine is in disfavor is the various attempts undertaken over the years to limit its use. Congress, recognizing the numerous problems created by the doctrine, has attempted to impose strict limitations on its application. The American Bar Association also has proposed modifications to the doctrine. These attempts have thus far met with virtually no success.

\section{A. The Hickenlooper Amendment}

In reaction to the Sabbatino decision, Congress in 1964 enacted the Hickenlooper amendment, ${ }^{393}$ sometimes called the Sabbatino

F.2d 1030, 1047 (9th Cir.) (The political question doctrine did not apply to suits between private parties involving private commercial activity, even though both United States and Canadian governments were intimately involved with the activity.), cert. denied, 464 U.S. 849 (1983).

${ }^{389}$ See McGowan, Congressmen in Court: The New Plaintiffs, 15 Ga. L. Rev. 241, 256-57 (1981), cited in Tel-Oren v. Libyan Arab Republic, 726 F.2d 774, 798 (D.C. Cir. 1984) (Edwards, J., concurring); see also Henkin, Is There a "Political Question" Doctrine?, 85 YALE L.J. 597 (1976).

${ }_{\text {s8o }}$ See Goldwater v. Carter, 444 U.S. 996, 1002 (1979) (mem.) (Rehnquist, J., concurring in judgment).

${ }^{301}$ See Gilligan v. Morgan, 413 U.S. 1, 10 (1973) (involving policies of the National Guard).

so2 See Colegrove v. Green, 328 U.S. 549 (1946) (assessing the validity of state law governing the apportionment of congressional districts).

${ }_{303}$ The Amendment was added to a foreign aid bill and promulgated as part of the Foreign Assistance Act of 1964, Pub. L. No. 88-633, § 301(d)(4), 78 Stat. 1009, $1012-13$ (1964) (current version at 22 U.S.C. $\$ 2370(\mathrm{e})(2)(1982)$ ). Named after its chief sponsor, Senator Hickenlooper, it is sometimes called the second Hickenlooper amendment, see, e.g., J. SWEENEY, C. OLIVER \& N. LEECH, supra note 61, at 390, to distinguish it from the first Hickenlooper amendment. The first Hickenlooper amendment was passed at the same time and directs the President to suspend foreign assistance to countries expropriating property of American citizens without compensation. See 22 U.S.C. $\S 2370($ e)(1) (1982). Like the second Hickenlooper amendment, the first 
amendment. The amendment provides in relevant part that

no court in the United States shall decline on the ground of the federal act of state doctrine to make a determination on the merits giving effect to the principles of international law in a case in which a claim of title or other rights to property is asserted by any party including a foreign state . . . based upon (or traced through) a confiscation or other taking . . . by an act of that state in violation of the principles of international law ....384

While at first blush this inartful language would seem to abolish large parts of the act of state doctrine, the amendment has had almost no effect on the doctrine. In fact, it has been applied successfully only once: in the remand of the Sabbatino litigation. ${ }^{395}$ The amendment has atrophied for several reasons. First, it has been interpreted narrowly to exclude all contract claims. A claim for breach of contract has been held not to be a "claim of title or other right to property"; nor is a repudiation of a contract considered a "confiscation or other taking" within the meaning of the amendment. ${ }^{396}$ Second, it has been held inapplicable to claims made by a foreign state's own nationals. ${ }^{397}$ Third, courts have read the amendment to require that the confiscated property or its proceeds be located in the United States; claimants cannot lay claim to other property that is within the United States to compensate for expropriated property abroad. ${ }^{398}$ With all these roadblocks, litigants have

Hickenlooper amendment has been of little practical use. Its invocation against Sri Lanka, for example, had no discernible effect. See J. Sweeney, C. Oliver \& N. LEECH, supra note 61 , at 392.

394 22 U.S.C. $\S 2370(e)(2)(1982)$.

${ }^{395}$ See Banco Nacional de Cuba v. Farr, 383 F.2d 166 (2d Cir. 1967), cert. denied, 390 U.S. 956 (1968). On remand, the Second Circuit first held that the amendment was constitutional, see $i d$. at 178-83, and then, with the amendment as new authority, ruled against Cuba on the grounds that the Cuban seizure of American assets violated international law. See id. at 183. For further discussion of the Sabbatino litigation, see supra notes 50-63 and accompanying text.

${ }^{398}$ See Menendez v. Saks \& Co., 485 F.2d 1355, 1372 (2d Cir. 1973), rev'd on other grounds sub nom. Alfred Dunhill of London, Inc. v. Republic of Cuba, 425 U.S. 682, 688 (1976); Occidental of Umm Al Qaywayn, Inc. v. Cities Serv. Oil Co., 396 F. Supp. 461, 472 (W.D. La. 1975).

${ }^{307}$ See F. Palicio y Compania, S.A. v. Brush, 256 F. Supp. 481,487 (S.D.N.Y. 1966), affd per curiam, 375 F.2d 1011 (2d Cir.), cert. denied, 389 U.S. 830 (1967); Present v. United States Life Ins. Co., 96 N.J. Super. 285, 303-04, 232 A.2d 863, 873 (N.J. Super. Ct. Law Div. 1967), aff'd per curiam, 51 N.J. 407, 241 A.2d 237 (1968).

${ }_{398}$ See Compania de Gas de Nuevo Laredo, S.A. v. Entex, Inc., 686 F.2d 322, 327 (5th Cir. 1982), cert. denied, 460 U.S. 1041 (1983); Empresa Cubana Exportadora de Azucar y Sus Derividados v. Lamborn \& Co., 652 F.2d 231, 237 (2d Cir. 1981); see also RestatemENT (REvised) OF FoREIGN REIATIONS LAW OF THE UnIted States $\S 429$ note 4 (Tent. Draft No. 4, 1983). But see Ramirez de Arellano 
generally abandoned the amendment as a means of avoiding the act of state doctrine.

\section{B. The Mathias Bill}

In 1981, Senator Charles Mathias, Jr., introduced a bill in the United States Senate proposing to limit the application of the act of state doctrine. ${ }^{389}$ The Mathias bill, titled the International Rule of Law Act, ${ }^{400}$ attempted to eliminate the doctrine in cases in which the foreign act of state is, in the court's view, "contrary to international law." To guide courts in making this determination, the bill directed them to article 38 of the Statute of the International Court of Justice, which lists applicable sources of international law. ${ }^{402}$

In its other provisions, the bill explicitly retained the foreign sovereign compulsion doctrine and implicitly retained the other defenses available in foreign transaction cases, such as the political question doctrine and forum non conveniens. The bill provided explicitly for the abolishment of the narrower, clearly ineffective Hickenlooper amendment. ${ }^{403}$

Extensive hearings were held on the Mathias bill, during which numerous international law scholars testified to the myriad problems created by the act of state doctrine. ${ }^{404}$ Despite this persuasive testimony, the bill failed to make it past the Senate Judiciary Committee. ${ }^{400}$

v. Weinberger, 745 F.2d 1500, 1542 n.180 (D.C. Cir. 1984) (en banc) (refusing to adopt this interpretation because it would amount to "[g]utting the Amendment"), vacated mem., 105 S. C.t. 2353 (1985).

${ }^{389}$ S. 1434, 97th Cong., 1st Sess. (1981), reprinted in Act of State Hearings, supra note 10 , at 3,4 .

400 The bill was originally titled the International Judicial Protection Act. See S. 2633, 96th Cong., 2d Sess. (1980). For the original version of the bill, see Mathias, supra note 2 , at 408 n.209.

${ }^{401}$ The bill, S. 1434, 97th Cong., 1st Sess. (1981), is reproduced in its entirety in Act of State Hearings, supra note 10, at 3; ACT OF STATE aND ExTRATERrITORIAL REACH, supra note 336, at 90 app. A; and Note, Limiting the Act of State Doctrine, supra note 2 , at $128 \mathrm{n} .136$.

4021947 I.C.J. Acts \& Docs. 37, 46, No. 1.

${ }^{403}$ See S. 1434, 97th Cong., 1st Sess. (1981), reprinted in Act of State Hearings, supra note 10 , at 3,5 (referring to the Hickenlooper amendment, 22 U.S.C. $\S 2370(\mathrm{e})(2)(1982))$.

104 See Act of State Hearings, supra note 10, at 5-146; see also ACT OF STATE AND Extraterritorial Reach, supra note 336, at 3-29 (describing an American Bar Association program on the Mathias bill and the act of state doctrine generally). To spur enactment of his bill, Sen. Mathias wrote an article discussing the problems created by the act of state doctrine. See Mathias, supra note 2, at 369-71; see also Note, Limiting the Act of State Doctrine, supra note 2, at 128-33 (analyzing the Mathias bill).

405 Even if the bill had become law, it is doubtful whether it would have achieved its intended purpose. As with the second Hickenlooper amendment, courts could have 


\section{G. The American Bar Association Proposal}

In August 1984, the American Bar Association approved a proposal, drafted by its international law-section, that would add an amendment to the FSIA preventing use of the act of state doctrine in instances in which sovereign immunity is found lacking under FSIA section 1605(a)(3). ${ }^{406}$ That section denies sovereign immunity to a foreign state in a case in which "rights in property taken in violation of international law are in issue"407 and the property has some connection with a commercial activity in the United States. The House Report on the FSIA defines takings in violation of international law to include nationalizations that are not accompanied by "prompt adequate and effective

interpreted the bill out of existence. The bill would have eliminated the act of state doctrine as a defense only to judicially defined violations of international law, and courts presumably could have avoided finding such violations. The courts' treatment of the Hickenlooper amendment suggests that they likely would follow this route. This would lead, contrary to Senator Mathias's intentions, to continued stagnation of international law in the United States. See Note, Limiting the Act of State Doctrine, supra note 2, at 123 n.114 ("The provisions of the [Hickenlooper] amendment illustrate the risks involved in allowing domestic courts to apply parochial versions of international law.").

The only effective solution, therefore, is complete abolition of the act of state doctrine, leaving the courts no discretion to continue its use. See infra Part V.

${ }^{408}$ See Report to the House of Delegates, 1984 A.B.A. SEC. INT'L L. Prac. 1. The act of state amendment is one of a group of "cleanup" amendments to the FSIA that the ABA International Law Section is proposing for unexpected problems that have appeared during the last seven years of the FSIA's existence. The amendments are described in two documents: a short four-page "Report," summarizing the amendments, and a longer "Recommendations" document, containing the full text of the FSIA as it would appear if the amendments were adopted.

In discussing the problems that the act of state doctrine has created for the FSIA, the Report states:

Experience has demonstrated that the Act's current provisions for adjudication of expropriation claims against foreign states, principally in Sections $1605(a)(3)$ and 1607, fail to provide an adequate remedy for many Americans who are the victims of foreign expropriations. This is true, inter alia, because many courts have continued to apply the act of state doctrine as a bar to adjudication of expropriation claims even in the narrow circumstances in which jurisdiction is expressly prescribed by law.

Report to the House of Delegates, supra, at 2.

The ABA recommendations include the addition of a new section 1606(b) to the FSIA that would read as follows:

The federal act of state doctrine shall not be applied on behalf of a foreign state with respect to any claim or counterclaim asserted pursuant to the provisions of this chapter which is based upon on expropriation or other taking of property (including contract rights) without the payment of prompt, adequate and effective compensation or otherwise is a violation of international law or which is based upon a breach of contract.

Recommendations on the Foreign Sovereign Immunities Act of 1976, 1984 A.B.A. SEC. INT'L L. Prac. 12.

${ }_{107} 28$ U.S.C. § $1605(\mathrm{a})(3)(1982)$. 
compensation" or that are "arbitrary or discriminatory in nature."

The ABA proposal may be viewed as another version of the Mathias bill. There are, however, two major distinctions: (1) the Mathias bill would have created a separate federal statute preventing the use of the act of state doctrine in cases involving international law violations, while the ABA proposal seeks to insert such a prohibition directly into the FSIA; and (2) the Mathias bill would have been applicable to litigation between private parties, while the ABA proposal is limited strictly to litigation involving foreign sovereigns. In effect, the ABA proposal seeks to rewrite in stronger terms the statement by the original FSIA drafters that the act of state doctrine should not apply to cases already covered by the FSIA. ${ }^{409}$ The ultimate fate of the ABA proposal is yet unknown. ${ }^{410}$

\section{A Proposed Statute to Abolish the Act of State Doctrine}

The courts are perhaps in the best position to abolish the act of state doctrine. ${ }^{411}$ The courts' past resistance to legislative efforts in this area, however, suggests that independent judicial action is highly unlikely. Moreover, an action of this scope would probably require a decisive ruling by the Supreme Court. The Supreme Court, however, has been reluctant even to hear cases in this area, and the Justices have shown a clear lack of consensus on an appropriate solution. Under these circumstances, a legislative solution appears necessary.

The legislative efforts discussed in part IV have been unsuccessful

${ }^{408}$ FSIA House REPORT, supra note 155, at 6618.

${ }^{409}$ See supra text accompanying notes 313-14.

410 On May 3, 1985, Senator Mathias introduced the ABA proposal in the Senate as S. 1071, "A Bill to amend the Foreign Sovereign Immunities Act." Hearings on S. 1071 were scheduled for September 1985, see INT'L L. News, Summer 1985, at 3, but now have been indefinitely postponed, pending the submission of written opinions on the bill by the Departments of State and Justice. Telephone conversation with Randy Collins, Office of Senator Mathias (Dec. 18, 1985). The ABA itself recognizes the difficulties with the bill. "Despite the apparent progress of the Bill over the past two years, attorneys at the State and Justice Departments reportedly have serious reservations about a number of provisions in the Bill . . . " INT'L L. NEws, supra, at 3.

The American Law Institute (ALI) also is currently considering the act of state doctrine, in its revision of the Restatement (Second) of Foreign Relations Law of the United States. The current ALI proposal, however, would only maintain the status quo. See supra note 301 (discussing Restatement (REvised) of Foreign RelaTIONS LAW OF THE UNITEd States, $\S 469$, at 361 (Tent. Draft No. 6, 1985)).

${ }^{111}$ Since the judiciary created the act of state doctrine, the judiciary has the power to abolish it. Professor Wallace quotes a sarcastic statement made to him by a Department of Justice official: "Why should this be for the legislature at all? It is a distinguished, dignified doctrine created by the courts, and why shouldn't they solve the problem?" Wallace, supra note 351, at 5. 
in solving the problems of the act of state doctrine. It is unlikely that any of the present proposals would have much effect, since they all allow courts the discretion to continue dismissing cases on act of state grounds. Effective legislative abolishment ${ }^{\mathbf{4 1 2}}$ requires simple language that unequivocally prohibits all further invocations of the doctrine. The doctrine could be successfully abolished with the following language:

The act of state doctrine shall not be available as a bar to consideration of any case on the merits in any court of the United States.

This language could exist either as a separate statute or as part of another law, such as the FSIA. Enactment of the provision would require that the courts invoke other, more precisely defined principles in order to abstain from cases involving international transactions. ${ }^{\mathbf{4 1 3}}$

112 In MOL, Inc. v. Peoples Republic of Bangladesh, 572 F. Supp. 79 (D. Or. 1983), aff'd, 736 F.2d 1326 (9th Cir.), cert. denied, 105 S. Ct. 513 (1984), the district court made the startling pronouncement that because the act of state doctrine has "constitutional underpinnings," as announced in Sabbatino, "Congress would have lacked the authority to limit the doctrine." Id. at 83. The district court's statement is a good example of both the misunderstanding that surrounds the doctrine and the undue respect that courts have placed on it. In fact, Congress has already once limited, or more accurately attempted to limit, the doctrine through the second Hickenlooper amendment, and this congressional action has been upheld by the courts. See Banco Nacional de Cuba v. Farr, 383 F.2d 166, 178-83 (2d Cir. 1967), cert. denied, 390 U.S. 956 (1968).

The court in Farr suggested, in dicta, that "a total prohibition on the courts, declaring that they might never resort to the act of state doctrine, might well be unconstitutional as violative of the separation of powers doctrine." Id. at 181 . The reasoning of the court may not be correct. As the Supreme Court explained in Sabbatino, while the act of state doctrine may have "constitutional underpinnings," "[t]he text of the Constitution does not require the act of state doctrine; it does not irrevocably remove from the judiciary the capacity to review the validity of foreign acts of state." Sabbatino, 376 U.S. at 423 . Even if the Second Circuit were correct, however, it provides little basis for challenging the proposal set forth in this Article. The court in Farr clearly distinguished between invocation of the act of state doctrine as "an abstention policy grounded upon the exercise of judicial discretion" and invocation that is "constitutionally compelled on the ground that the underlying issue [is] a political question." $I d$. at 180-81. Finding the Sabbatino litigation to fall within the former category, the court concluded that the Hickenlooper amendment did not unconstitutionally interfere with the power of the judiciary.

Following abolishment of the act of state doctrine, courts would still be permitted to invoke the political question doctrine in those particular instances, if any, in which abstention is truly compelled by the Constitution. This level of discretion adequately satisfies the concerns raised in Farr while limiting the courts' ability to abstain from cases without articulating specific and persuasive justication.

${ }^{113}$ The proposed statute already has one prominent supporter on the record. During the hearings on the Mathias bill to limit the scope of the act of state doctrine, Professor Don Wallace, Jr., director of the Georgetown University International Law Institute, stated, "Indeed, I would be prepared to support a bill that abolished the act of state doctrine in its entirety." Act of State Hearings, supra note 10, at 28. 


\section{CONCLUSION}

The act of state doctrine is used by courts to avoid deciding international transaction cases that have some foreign governmental involvement. Courts are hopelessly confused about the meaning and scope of the doctrine, however, and more often than not use the doctrine simply to avoid deciding difficult cases. Moreover, the doctrine is applied inconsistently, and parties structuring an international transaction often cannot predict whether the doctrine will prevent adjudication of claims arising from the transaction.

Faced with such confusion with other judicially created doctrines, courts in the past have abandoned those doctrines in favor of a more reasoned and principled analysis. The same should be done with the act of state doctrine: it, too, should be abandoned. In its place, courts can use doctrines that encompass the same concerns as the act of state doctrine, but, unlike that doctrine, have reasoned criteria for their application. 